\title{
Introduction to the Carta Marina
}

\subsection{Introduction}

This book is devoted to an imposing world map, printed on twelve sheets and rich in detail, that was designed by the German cartographer Martin Waldseemüller in 1516, whose only surviving exemplar is in the Jay I. Kislak Collection at the Library of Congress. This map, the Carta marina, has tended to live in the shadow of Waldseemüller's earlier world map, that printed in 1507, which is famous for being the first to apply the name "America" to the New World. The Carta marina lacks some of the striking audacity of the 1507 map, on which the cartographer not only debuts a new name for the newly discovered lands in the west, but also represents all 360 degrees of longitude at a time when the interior and the western reaches of the New World were unknown, and the vastness of the Pacific was still undiscovered by Europeans. On the Carta marina, by contrast, he more prudently omits as unknown everything between the eastern coast of the New World and the eastern coast of mainland Asia. Yet the Carta marina is the fruit of a cartographic boldness that is equally impressive: a willingness to discard almost all of the research done for the earlier map, and undertake the laborious creation of an entirely new detailed and monumental image of the world based on a new philosophy and a new projection, and using new sources. The map is a remarkable testament both to the cartographer's determination to show the true form of the world and to the dynamism of early sixteenth-century cartography.

One of the many differences between the 1507 and 1516 maps is that there is a larger number of long legends on the latter. In the long text block in the lower left corner of the map (see Legend 9.3), Waldseemüller lists many of the sources that he used in creating the map, which are also the sources of many of the long legends. He clearly viewed the textual element of his map as very important, and yet in the more than one hundred years since the rediscovery of the Carta marina, few of the legends have been transcribed and translated, they have never been studied together, and their correlations with the sources that Waldseemüller lists on the map have not been explored. ${ }^{1}$ Thus an essential aspect of this important map, and of Waldseemüller's effort to convey information to the map's viewers, has remained uninvestigated.

We know little about Waldseemüller, and the general lack of scholarly attention devoted to the Carta marina represents not only a failure to address one of the masterpieces of the most important cartographer of the early sixteenth century, but also a lost opportunity to study the development of his cartographic thought, and thus add to our knowledge of the man. By examining how he used his sources, we can gain insight into Waldseemüller's methods and character, and by seeing how his cartographic thought evolved, we can come to appreciate his intellectual openness and flexibility.

In this introduction I offer a detailed discussion of the Carta marina, focusing on a comparison of that map with the 1507, and also with the maps in Waldseemüller's edition of Ptolemy's Geography published in 1513, in the interest of revealing all that the later map can tell us about the development of Waldseemüller's thought. Following this general discussion of the map comes a transcription, translation, and study of all of the long legends on the Carta marina, with particular attention devoted to the determination of their sources. My hope is that the book will be of use not only to readers with a direct interest in Waldseemüller, but also more broadly to any scholar working on early sixteenth-century cartography, and to anyone interested in seeing how an experienced cartographer of that period went about constructing a new image of the world.

\footnotetext{
${ }^{1}$ All of the toponyms on the Carta marina, but not the legends, are transcribed by Meret Petrzilka, Die Karten des Laurent Fries von 1530 und 1531 und ihre Vorlage, die 'Carta Marina' aus dem Jahre 1516 von Martin Waldseemüller (Zurich: Neuen Zürcher Zeitung, 1970), pp. 42-110.
} 
This book is accompanied by Electronic Supplementary Material, available from the page for this book on www.springer. com. These materials include high-resolution images of each sheet of the Carta marina and a high-resolution image of the whole map. In the book itself there is an illustration of each sheet of the map at the beginning of the section about the texts on that sheet, but the high-resolution online images of the sheets will allow the reader to zoom in and better see the details being discussed.

The ESM also includes an index PDF of the whole map that indicates with a number the location of each of the long texts on the map that are transcribed, translated, and studied below. This PDF is searchable, so that if the reader is having difficulty determining where exactly Legend 8.7 is located, a search in the PDF for "8.7" will find it.

\subsection{Martin Waldseemüller and His Works}

Martin Waldseemüller was born between 1470 and 1475, either in Freiburg or the nearby village of Wolfenweiler, and studied at the University of Freiburg: he is registered as a student there in 1490. In about 1505 he moved to the town of Saint-Dié in the Vosges Mountains not far from Strasbourg, and in 1513 he became a canon of the collegiate church there, though at the time he was living in Strasbourg. Aside from that stay in Strasbourg, he spent his adult life in Saint-Dié, ${ }^{2}$ and died there in $1520 .^{3}$

In Saint-Dié, Waldseemüller worked with a small group of humanists who sometimes called themselves the Gymnasium Vosagense. There is no evidence that this group was involved in teaching, and it seems only to have been an association of scholars. The group was led by Gualtier Ludd, secretary to Duke René II of Lorraine, and the owner of a small press in Saint-Dié ${ }^{4}$; the other members that we know of were Gualtier's cousin Nicholas Ludd, Matthias Ringmann, and Johannes Basinus Sendacurius. 5

It is by following Waldseemüller's development as a cartographer through his works that we can learn the most about him. Those works are as follows ${ }^{6}$ :

1. In 1507, Waldseemüller, in close collaboration with Matthias Ringmann, published three works that were designed to accompany each other. The first was a short book, the Cosmographie introductio, printed in Saint-Dié, no doubt on Ludd's press, which is an introduction to geography followed by a Latin translation of Amerigo Vespucci's account of

\footnotetext{
${ }^{2}$ For biographical details about Waldseemüller see Lucien Gallois, "Waldseemüller, chanoine de Saint-Dié," Bulletin de la Société de Géographie de l'Est 21 (1900), pp. 221-229; P. Albert, “Über die Herkunft Martin Walzenmüller's, genannt Hylacomylus," Zeitschrift für die Geschichte des Oberrheins 15 (1900), pp. 510-514; Hermann Flamm, "Die Herkunft des Kosmographen Martin Waldseemüller (Walzenmüller)," Zeitschrift für die Geschichte des Oberrheins 27.1 (1912), pp. 41-52; Franz Laubenberger, "Martin Waldseemüller. Ein kurzer Abriß über Leben und Werk des Freiburger Kartographen," Vermessungstechnische Rundschau 27.8 (1965), pp. 306-310; 27.9 (1965), pp. 356-358; and 27.10 (1965), pp. 384386; and Hans Wolff, "Martin Waldseemüller: The Most Important Cosmographer in a Period of Dramatic Scientific Change," in Hans Wolff, ed., America: Early Maps of the New World, trans. Hugh Beyer et al. (Munich: Prestel, 1992), pp. 111-126.

${ }^{3}$ Chet Van Duzer and Benoît Larger, "Martin Waldseemüller's Death Date," Imago Mundi 63.2 (2011), pp. 217-219, and see Chet Van Duzer, “A Printer's Silent Tribute to the Passing of Martin Waldseemüller in Early Sixteenth-Century Strasbourg," Papers of the Bibliographical Society of America 110.3 (2016), pp. 313-333.

${ }^{4}$ On the printing press in Saint-Dié see Arthur Benoit, "Notes sur les commencements de l'imprimerie à Saint-Dié," Bulletin de la Société philomatique vosgienne 13 (1887-88), pp. 183-208; and Albert Ronsin, "L'imprimerie humaniste de Saint-Dié au XVIe siècle," in Emil van der Vekene, ed., Refugium animae bibliotheca: Festschrift für Albert Kolb (Wiesbaden: G. Pressler, 1969), pp. $382-425$.

${ }^{5}$ On Waldseemüller's collaborators in the Gymnasium Vosagense see M. d'Avezac, Martin Hylacomylus Waltzemüller, ses ouvrages et ses collaborateurs: voyage d'exploration et de découvertes à travers quelques épîtres dédicatoires, préfaces et opuscules en prose et en vers du commencement du XVI siècle: notes, causeries et digressions bibliographiques et autres (Paris: Challamel âiné, 1867); and Lucien Gallois, "Le Gymnase Vosgien," Bulletin de la Société de Géographie de l'Est 21 (1900), pp. 88-94. On Ringmann see Charles Schmidt, "Mathias Ringmann (Philésius), humaniste alsacien et lorrain," Mémoires de la Société d’Archéologie Lorraine 25 (1875) pp. 165-233; Charles Schmidt, Histoire littéraire de l'Alsace à la fin du XVe siècle (Paris: Sandoz and Fischbacher, 1879-80), vol. 2, pp. 87-131; and Benoît Larger, "Le Gymnase vosgien et ses réseaux: les cardinaux: Lettre de Procuration de René II, roi de Sicile et duc de Lorraine à François Sodérini, cardinal de Sainte-Suzanne," in Saint-Dié-des-Vosges baptise les Amériques: actes du colloque, 12 mai 2007, Centre Robert-Schuman, Saint-Dié-des-Vosges (Saint-Dié-des-Vosges: Musée Pierre Noël, 2008), pp. 82-85. On the question of whether Waldseemüller or Ringmann should be credited with the naming of America see Franz Laubenberger (trans. Steven Rowan), "The Naming of America," The Sixteenth Century Journal 13.4 (1982), pp. 91-113, with some corrections in Christine R. Johnson, "Renaissance German Cosmographers and the Naming of America," Past \& Present 191 (2006), pp. 3-43.

${ }^{6}$ For a good account of Waldseemüller's works see Robert W. Karrow, Mapmakers of the Sixteenth Century and Their Maps: Bio-Bibliographies of the Cartographers of Abraham Ortelius, 1570 (Chicago: Speculum Orbis Press, 1993), pp. 568-583.
} 
his four voyages. ${ }^{7}$ The second was a set of woodcut gores for a terrestrial globe with a diameter of $12 \mathrm{~cm}(4.5$ inches); the printer is not specified. ${ }^{8}$ And the third was the 1507 world map, printed on twelve sheets, each approximately $45.5 \times 62 \mathrm{~cm}$ (about $18 \times 24.4$ inches), which were designed to be assembled into a wall map measuring $128 \times 233 \mathrm{~cm}(50.4 \times 91.7$ inches $) .{ }^{9}$ The map is titled Universalis Cosmographia Secundum Ptholomaei Traditionem et Americi Vespucii Alioru[m]que Lustrationes (A map of the whole world according to the tradition of Ptolemy and the explorations of Amerigo Vespucci and others). This map is the first to apply the name "America" to the New World, a name that Waldseemüller and Ringmann proposed in the Cosmographiae introductio. The printer of the map is not indicated. It survives in just one exemplar, which was owned by the astronomer, mathematician, and globemaker Johann Schöner (1477-1547) and preserved by him in a codex now called the Schöner Sammelband. ${ }^{10}$ The codex was discovered in 1901 by Joseph Fischer in Wolfegg Castle in Baden-Württemberg, Germany; in 2003, the Library of Congress completed its acquisition of the map. ${ }^{11}$ Elsewhere I have shown that the 1507 map, not only in terms of overall design and projection but also with regard to its long descriptive texts - but not with regard to its place names - is based closely on the large world map by Henricus Martellus at Yale, which was made c. 1491 — or rather, not on the specific map at Yale, but on another, similar large map by Martellus that is now lost. ${ }^{12}$

\footnotetext{
${ }^{7}$ The full title of the book refers to the accompanying map and globe (this is the title of the first edition): Cosmographiae introductio: cum quibusdam geometriae ac astronomiae principiis ad eam rem necessariis. Insuper quatuor Americi Vespucij nauigationes. Uniuersalis cbosmographiae $[$ sic] descriptio tam in solido q[uam] plano eis etiam insertis qu[a]e Ptholom[a]eo ignota a nuperis reperta sunt (Saint-Dié: [Gualtier and Nicholas Ludd], 1507). On the Cosmographiae introductio see Henry Harrisse, Bibliotheca americana vetustissima: A Description of Works Relating to America, Published between the Years 1492 and 1551 (New York: G. P. Philes, 1866), \#44-47, pp. 89-96; the work is reproduced in facsimile and translated into English by Joseph Fischer and Franz von Wieser in The 'Cosmographiae introductio' of Martin Waldseemüller in Facsimile, Followed by the Four Voyages of Amerigo Vespucci, with their Translation into English (New York: The United States Catholic Historical Society, 1907). A new translation and discussion of the Cosmographiae introductio by John Hessler may be found in his The Naming of America: Martin Waldseemüller's 1507 World Map and the 'Cosmographiae introductio' (London: D. Giles, 2008). There is a French translation by Pierre Monat in Albert Ronsin, La fortune d'un nom: America: le baptême du Nouveau Monde à Saint-Dié-des-Vosges (Grenoble: J. Millon, 1991), pp. 101-219. The work has also been reproduced in facsimile and translated into Spanish by Miguel León-Portilla in Introducción a la cosmografía y las cuatro navegaciones de Américo Vespucio (Coyoacán: Universidad Nacional Autónoma de México, 2007); the accompanying CD includes Spanish translations of all of the long legends on Waldseemüller's 1507 map. There also is a facsimile with transcription and translation into German in Martin Lehmann, Die 'Cosmographiae Introductio' Matthias Ringmanns und die Weltkarte Martin Waldseemüllers aus dem Jahre 1507: Ein Meilenstein frühneuzeitlicher Kartographie (Munich: Martin Meidenbauer, 2010).

${ }^{8}$ There are five known surviving copies of the gores: at the University of Minnesota, in the Stadtbucherei Offenburg, at Charles Frodsham and Co. Ltd. (purchased at the Christie's sale of June 8, 2005), at the Bayerische Staatsbibliothek in Munich and at the Universitätsbibliothek in Munich (discovered in 2012). Serious questions have been raised about the genuineness of the exemplar in the Universitätsbibliothek in Munich: see Michael Blanding, "Why Experts Don't Believe This Is a Rare First Map of America," New York Times, Dec. 10, 2017. For general discussion of the gores see Henry Harrisse, The Discovery of North America (London: H. Stevens, 1892; Amsterdam: N. Israel, 1961), pp. 440-442, no. 67, and 467-468, no. 82; Fischer and von Wieser in The 'Cosmographiae introductio' of Martin Waldseemüller (see note 7), pp. 23-30; Edward L. Stevenson, Terrestrial and Celestial Globes: Their History and Construction (New Haven: Yale University Press, 1921), vol. 1, pp. 70-71; Americana vetustissima: Fifty Books, Manuscripts, \& Maps Relating to America from the First Fifty Years after its Discovery (1493-1542) (New York: H. P. Kraus, 1990), pp. 30-31; and Cartography, Including the Waldseemüller Gores: Wednesday 8 June 2005 (London: Christie, Manson \& Woods Ltd., 2005).

${ }^{9}$ Waldseemüller's 1507 map has been published in facsimile in Joseph Fischer and Franz Ritter von Wieser, Die älteste Karte mit dem Namen Amerika aus dem Jahre 1507 und die Carta marina aus dem Jahre 1516 des M. Waldseemüller (Ilacomilus) (Innsbruck: Wagner'schen Universitäts-Buchhandlung, 1903; Amsterdam: Theatrum Orbis Terrarum, 1968), with a good but brief introduction; and in John W. Hessler and Chet Van Duzer, Seeing the World Anew: The Radical Vision of Martin Waldseemüller's 1507 \& 1516 World Maps (Washington, DC: Library of Congress and Delray Beach, FL: Levenger Press, 2012). There are two excellent high-resolution scans of the map available on the internet site of the Library of Congress. For discussion of the 1507 map, in addition to the introductions in the two facsimile editions see Charles G. Herbermann, “The Waldseemüller Map of 1507," Historical Records and Studies 3.2 (1904), pp. 320-342; Elizabeth Harris, "The Waldseemüller World Map: A Typographic Appraisal," Imago Mundi 37 (1985), pp. 30-53; and Toby Lester, The Fourth Part of the World: The Race to the Ends of the Earth, and the Epic Story of the Map that Gave America its Name (New York: Free Press, 2009).

${ }^{10}$ For a description of the Schöner Sammelband see John W. Hessler, "The Schöner Sammelband," in Arthur Dunkelman, ed., The Jay I. Kislak Collection at the Library of Congress: A Catalog of the Gift of the Jay I. Kislak Foundation to the Library of Congress (Washington, DC: Library of Congress, 2007), pp. 99-108.

${ }^{11}$ On the Library of Congress's acquisition of Waldseemüller's 1507 map see John Hébert, "The Map that Named America: Martin Waldseemüller's 1507 World Map," Coordinates, Series B, No. 4 (August, 2005), available at http://purl.oclc.org/coordinates/coordinates.htm.

${ }^{12}$ See Chet Van Duzer, Henricus Martellus's World Map at Yale (c. 1491): Multispectral Imaging, Sources, Influence (New York: Springer, 2018). Also see Chet Van Duzer, "Multispectral Imaging for the Study of Historic Maps: The Example of Henricus Martellus's World Map at Yale," Imago Mundi 68.1 (2016), pp. 62-66; and my talk "New Light on Henricus Martellus's World Map at Yale (c. 1491): Multispectral Imaging and Early Renaissance Cartography," delivered in the Caroline Werner Gannett Distinguished Speaker Series in Digital Humanities at the Chester F. Carlson Center for Imaging Science, Rochester Institute of Technology, March 18, 2015, with video available at https://www.cis.rit.edu/martellus.
} 
2. In 1511, Waldseemüller produced a wall map of Europe on four sheets that measured $141 \times 107 \mathrm{~cm}$ (about $56 \times 42$ inches). This map, the Carta Itineraria Europae,$^{13}$ is the first printed wall map of the continent, and the first map of Europe to show (as its name suggests) the most important trade routes. No copies of the 1511 printing survive, but one exemplar of the 1520 printing is extant. ${ }^{14}$ The map was accompanied by a short book written by Ringmann that supplies a more detailed description of the regions of Europe than there is room for on the map, titled Instructio manuductionem prestans in cartam itinerariam Martini Hilacomili (Strasbourg: Grüninger, 1511). ${ }^{15}$

3. In 1513 a new edition of Ptolemy's Geography, on which Waldseemüller together with Matthias Ringmann and other colleagues had begun work in 1505, but which suffered various delays, was printed by Johann Schott in Strasbourg. ${ }^{16}$ In addition to the standard twenty-seven Ptolemaic maps, this edition has a very full collection of tabulae modernae or modern maps based on more recent data, all but one based on information from nautical charts. This was the most important edition of Ptolemy published in the sixteenth century. ${ }^{17}$

4. In 1516, Waldseemüller published the Carta marina, which like the 1507 map is printed on twelve sheets, each approximately $45.5 \times 62 \mathrm{~cm}$ (about $18 \times 24.4$ inches), which were designed to be assembled into a wall map measuring $128 \times 233 \mathrm{~cm}(50.4 \times 91.7$ inches $) .{ }^{18}$ The printer of the map is not specified. Also like the 1507 map, the Carta marina survives in just one copy, which was owned by Johann Schöner (1477-1547), and which was preserved together with a copy of the 1507 map in the Schöner Sammelband. ${ }^{19}$ Following the Library of Congress's purchase of the 1507 map, the collector Jay I. Kislak bought the Sammelband, minus the 1507 map and a star chart by Albrecht Dürer. He has donated much of his large collection of Americana, including the Sammelband with the Carta marina, to the Library of Congress, where the map now resides. ${ }^{20}$ In a separate transaction in 2016 the Library of Congress acquired the Dürer star chart that had been in the Sammelband, and thus now owns all of the elements that originally comprised the Sammelband.

Towards the end of his life Waldseemüller was working on books titled Itineraria and Chronica mundi, which had been promised to the publisher Johann Grüninger, but were never completed or printed. ${ }^{21}$ The brief references to these works have

\footnotetext{
${ }^{13}$ The map bears the title Carta itineraria Europae, "Road map of Europe," along its bottom edge; along the top and bottom borders, there is a fuller title: Carta Europae topica neoterica civitatum fluviorum et montium [di]tancias eciam situs tam medi[d]os quam veros indicans, opus corographic [um] et geographicum Martini Ilacomili Friburgensis, "Modern map of Europe showing the distances and locations (both measured and accurate) of cities, rivers, and mountains, a chorographic and geographical work by Martin Waldseemüller of Freiburg."

${ }^{14}$ The single exemplar of the 1520 printing of the Carta itineraria Europae is in Innsbruck, Tiroler Landesmuseum Ferdinandeum, Historische Sammlungen, Kartographie, K 9/39. For discussion of the map see Leo Bagrow, "CCarta Itineraria Europae' Martini Ilacomili, 1511,” Imago Mundi 11 (1954), pp. 149-150; Peter H. Meurer, Corpus der älteren Germania-Karten: ein annotierter Katalog der gedruckten Gesamtkarten des deutschen Raumes von den Anfängen bis um 1650 (Alphen aan den Rijn: Canaletto Uitgeverij, Repro-Holland, 2001), pp. 155-160; and Albert Ronsin, “Carta itineraria Europae. La première carte routière murale d'Europe, éditée à Saint-Dié en 1511,” Mémoire des Vosges 3 (2001), pp. 6 12, and 4 (2002), pp. 10-13. The map has been reproduced in facsimile as Martin Waldseemüller, Carta itineraria Europae (Bonn: Kirschbaum Verlag, 1972), with an accompanying study by Karl-Heinz Meine, Erläuterungen zur ersten gedruckten (Strassen-)Wandkarte von Europa, der Carta itineraria Evropae der Jahre 1511 bzw. 1520 von Martin Waldseemüller (um 1470 bis etwa 1521), Kostbarkeit des Tiroler Landesmuseum Ferdinandeum, Innsbruck (Bonn-Bad Godesberg: Kirschbaum, 1971).

${ }^{15}$ There is a brief discussion of the Instructio manuductionem prestans in M. d'Avezac, Martin Hylacomylus Waltzemüller (see note 5), pp. 135-141.

${ }^{16}$ Incidentally in my article "Colored as its Creators Intended: Painted Maps in the 1513 Edition of Ptolemy's Geography," forthcoming in Imago temporis, I identify the workshop hand-coloring scheme for the maps in the 1513 edition of Ptolemy's Geography, that is, the coloring scheme intended by Waldseemüller and the other creators of the edition.

${ }^{17}$ For discussion of the 1513 edition of Ptolemy's Geography see Ruthardt Oehme, "Martin Waldseemüller und der Straßburger Ptolemäus von 1513," in Karl Friedrich Müller, ed., Beiträge zur Sprachwissenschaft und Volkskunde: Festschrift für Ernst Ochs zum 60 Geburtstag (Lahr: M. Schauenburg, 1951), pp. 155-167; R. A. Skelton, "Bibliographical Note," in Ptolemy, Geographia, Strassburg, 1513 (Amsterdam: Theatrum Orbis Terrarum, 1966), pp. v-xx; Patrick Gautier Dalché, "The Reception of Ptolemy's Geography (End of the Fourteenth to Beginning of the Sixteenth Century)," in David Woodward, ed., The History of Cartography, vol. 3, Cartography in the European Renaissance (Chicago: University of Chicago Press, 2007), part 1, pp. 285-364, at 348-349; and Alfred Hiatt, "Mutation and Supplement: The 1513 Strasbourg Ptolemy," in Zur Shalev and Charles Burnett, eds., Ptolemy's 'Geography' in the Renaissance (London: Warburg Institute, and Turin: Nino Aragno Editore, 2011 ), pp. 143-161. ${ }^{18}$ The Carta marina was reproduced in facsimile together with the 1507 map in Joseph Fischer and von Wieser, Die älteste Karte mit dem Namen Amerika (see note 9), with a good brief discussion in the introduction; and in Hessler and Van Duzer, Seeing the World Anew (see note 9). The map is also discussed by Seymour I. Schwartz, Putting 'America' on the Map: The Story of the Most Important Graphic Document in the History of the United States (Amherst, NY: Prometheus Books, 2007), pp. 197-206.

${ }^{19}$ On the Schöner Sammelband see note 10 above.

${ }^{20}$ See Arthur Dunkelman, ed., The Jay I. Kislak Collection at the Library of Congress: A Catalog of the Gift of the Jay I. Kislak Foundation to the Library of Congress (Washington, D.C.: Library of Congress, 2007), esp. 105-107 on the Carta marina.

${ }^{21}$ On these two unfinished books of Waldseemüller see Oskar von Hase, Die Koberger: Eine Darstellung des buchhändlerischen Geschäftsbetriebes in der Zeit des Überganges vom Mittelalter zur Neuzeit (Leipzig: Breitkopf \& Härtel, 1885), p. 138, and "Briefanhang" nos. 106, 117, and 123; and Hildegard Binder Johnson, Carta marina: World Geography in Strassburg, 1525 (Minneapolis, MN: University of Minnesota Press, 1963), pp. 39, 41, 44, 45, 57, and 95-96. On p. 95 Johnson translates part of letter 123 in von Hase.
} 
given rise to claims that some of the maps in the 1522 edition of Ptolemy's Geography published by Grüninger were made by Waldseemüller and intended for one of these books, but this is unlikely to be true, as Waldseemüller had been moving away from Ptolemy for some years before his death. It has been plausibly argued, however, that Waldseemüller's notes for these books were used by Lorenz Fries in writing his Uslegung der mercarthen oder Charta Marina, the booklet that accompanied Fries's 1525 edition of Waldseemüller's Carta marina, and was published by Grüninger in Strasbourg. ${ }^{22}$

In addition, the Uslegung contains a map showing the route that Alvise Cadamosto took on his voyage to Madeira and the Canary Islands in $1455,{ }^{23}$ and it is very likely that Waldseemüller made this map for either the Chronica mundi or the Itineraria. $^{24}$ Further, a copy of Francanzio de Montalboddo's Itinerarium Portugallensium (Milan, 1508) in the Österreichische Nationalbibliothek in Vienna (signature 394.092-C.Kar) has a set of six maps that have been added to the book, a world map and five maps of the coast of West Africa that illustrate the voyages of Cadamosto (1455/56) and Pedro de Sintra (1463). One of these maps is very similar to (but not identical with) that in the 1525 Uslegung, and it seems likely that they were produced as part of the preparations for the Chronica mundi or Itineraria, either by Waldseemüller or by a closely affiliated cartographer. ${ }^{25}$ But some passages in the Uslegung and these maps are all that we have of Waldseemüller's final projects.

\subsection{Comparing and Contrasting the 1507 and 1516 Maps}

As mentioned above, Waldseemüller's Carta marina, like his 1507 map, is printed on twelve sheets that were designed to be assembled into a wall map measuring $128 \times 233 \mathrm{~cm}(50.4 \times 91.7$ inches $)$. But while they share these physical characteristics, in most other respects the two maps are very different, and the differences are reflected in their titles. The title of the 1507 map, as mentioned above, is Universalis cosmographia secundum Ptholomaei traditionem et Americi Vespucii alioru [m]que lustrationes ("A map of the whole world according to the tradition of Ptolemy and the explorations of Amerigo Vespucci and others). Waldseemüller's use of both Ptolemy and Vespucci as sources-of both ancient and modern authorities - is indicated in the portraits of them at the top of the 1507 map.

But the title of the 1516 map indicates a radical repudiation of ancient authorities:

Carta marina navigatoria portugallen[siorum] navigationes atque totius cogniti orbis terre marisque formam naturamque situs et terminos nostri[s] temporibus recognitos et ab antiquorum traditione differentes eciam quorum vetusti non meminuerunt autores, hec generaliter indicat.

A nautical chart that comprehensively shows the Portuguese voyages and the shape and nature of the whole known world, both land and sea, its regions, and its limits as they have been determined in our times, and how they differ from the tradition of the ancients, and also areas not mentioned by the ancients.

The change from Waldseemüller's following Ptolemy to repudiating him is dramatic, and illustrates a dichotomy of Renaissance culture: on the one hand, admiration for the methods of enquiry and systems of knowledge of the ancients, and on the other, recognition that new investigations or explorations could produce results superior to those of the ancients-for example, the discovery that the equatorial Torrid Zone, which various classical authors held to be uninhabitable and uncrossable, was a myth. ${ }^{26}$ In a long introductory text in the lower left corner of the Carta marina, Waldseemüller discusses his earlier map (certainly the 1507 map), ${ }^{27}$ and his reasons for creating a new one. He concedes that a map with ancient place

\footnotetext{
${ }^{22}$ On Fries's use of Waldseemüller's notes in the Uslegung see Johnson, Carta marina (see note 21), pp. 96-99.

${ }^{23}$ The map of Cadamosto's voyage is only in the 1525 edition of the Uslegung, not in the 1527 or 1530 editions.

${ }^{24}$ So Robert W. Karrow Jr., Mapmakers of the Sixteenth Century and Their Maps (Chicago: Speculum Orbis Press, 1993), pp. $582-583$.

${ }^{25}$ See Peter H. Meurer, "Sechs Karten der westafrikanischen Küste aus der Waldseemüller-Schule," Cartographica Helvetica 45 (2012), pp. 15-26.

${ }^{26}$ For discussion of passages in which Renaissance authors express their doubts about the correctness of the ancients see R. Hooykaas, Humanism and the Voyages of Discovery in 16th Century Portuguese Science and Letters (Amsterdam and New York: Noord-Hollandsche U.M., 1979). For discussion of the Torrid Zone see Milton V. Anastos, "Pletho and Strabo on the Habitability of the Torrid Zone," Byzantinische Zeitschrift 44 (1951), pp. 7-10; and Angelo Cattaneo, "Réflexion sur les climats et les zones face à l'expansion des XVe et XVI siècles," Bulletin du Comité Français de Cartographie 199 (March, 2009), pp. 7-21.

${ }^{27}$ Peter W. Dickson, The Magellan Myth: Reflections on Columbus, Vespucci, and the Waldseemueller Map of 1507 (Mount Vernon, Ohio: Printing Arts Press, 2007), questions whether the earlier map described is in fact the 1507 map, asserting that Waldseemüller says that the earlier map represents the world according to Ptolemy, while the 1507 map contains more than that. Unfortunately this doubt is based on a misinterpretation or incomplete reading of Waldseemüller's text. After Waldseemüller writes that he designed his earlier map so that "it would only have in it those customs and features that are known to have been extant or in use in Ptolemy's time," he continues: "Many things were added that were discovered and confirmed by the testimony of experience by the Venetian citizen Marco during the papacies of Clement IV and Gregory X, and by the Portuguese captains Christopher Columbus and Amerigo Vespucci.”.
} 
names, like his earlier map, is of limited utility, since it is difficult to recognize modern places according to their ancient names, and also remarks that recent explorers have detected various errors in the geographical writings of the ancients, particularly in Ptolemy's Geography. He then writes ${ }^{28}$ :

Quibus ipse permotus communi eruditorum utilitati studens hunc secundarium totius orbis typum primo adieci, ut sicut illic veterum constetit auctorum totius orbis terra marique descriptio, sic reluceat hic non noua solum ac presens totius orbis facies, sed cum hoc mediorum temporum indita rebus mortalibus consueta et naturalis permutatio pateat ut unico habeas (si ita dici iubet) contuitu quid, quales, quomodo res caduce nunc fiunt, qualesque priscis fuerint temporibus et quales aliquin future a nobis nullatenus dubitari possint. Hanc igitur iuxta Neotericorum traditionem totius orbis spetiem \& descriptionem Chartam placuit appellare marinam, eo que in maris descriptionibus vulgarem fuerimus \& approbatissimam nauticarum tabularum notificationes insequuti, sumus insuper in mediterranea Asie atque Aphrice descriptione $\mathrm{Ne}[\mathrm{o}]$ tericorum itinerarios, particulares tabulas, chorographias, \& quorundam recensiorum [for recentiorum] lustratorum relationes plerumque imitati....

Moved by these considerations, and in the interest of the common utility of scholars, I have added this second image of the world to my first, so that just as in the first the image of the whold world, land and sea, agreed with that of the ancient authors, so in this one, not only may the new and present face of the world shine forth, but together with that, the customary and natural change introduced into worldly affairs in the intervening times, so that you can see (if I may say so) at a single glance why, of what kind, and how transitory things have come to be now, what they were like in former times, and how they will be in the future, without a doubt. Therefore, it seemed good to call this image and description of the whole world, made in accordance with the tradition of modern authors, a Carta marina, and for that reason, as far as the depiction of the oceans, I have followed the commonly used and the most approved nautical charts and their indications, while in the depiction of the Mediterranean, Asia and Africa I have made ample use of recent authors' travel narratives, regional maps, descriptions of countries, and the accounts of some recent explorers....

Though his 1507 map shows the New World, Waldseemüller here describes his earlier work as an image of the earth according to the ancients, no doubt to increase the attractiveness of his new map, which is based on the most recent information available.

Together with this change in his thought about what a world map should be came a closely related change in cartographic models. His 1507 map is based on Ptolemy's Geography — not only on Ptolemy's geographical data regarding the locations of cities and other features in Europe, Africa and Asia, but also on his system for representing geographical space, using a grid of latitude and longitude. More specifically, Waldseemüller used as the model for his 1507 map a large world map of c. 1491 by Henricus Martellus Germanus (Fig. 1.1). ${ }^{29}$ Martellus's map uses the Ptolemaic grid of latitude and longitude, and is laid out using a modification of Ptolemy's second projection. Waldseemüller followed Martellus closely (Fig. 1.2), and used the same projection, has similar decorative wind-heads in the border of the map, arranged things so that Japan is at the eastern or right-hand edge of the map as it is on Martellus's, and borrowed many descriptive texts from Martellus. ${ }^{30}$ Waldseemüller of course added the New World, often used different sources for place names, and depicted southern Africa very differently, but in other respects he made heavy use of Martellus, particularly for the outlines of Asia and for his long descriptive texts.

In his Carta marina Waldseemüller abandoned the Ptolemaic model, and instead adopted the model of nautical charts or portolan charts. ${ }^{31}$ The origin of nautical charts is unclear, but the earliest surviving examples date to the late thirteenth

\footnotetext{
${ }^{28}$ For the full Latin text and English translation of this introductory paragraph see Legend 9.3.

${ }^{29}$ Martellus's world map of c. 1491 is $122 \times 201 \mathrm{~cm}$, almost as large as Waldseemüller's 1507 map $(128 \times 233 \mathrm{~cm})$. The map is on permanent display in the Beinecke Rare Book and Manuscript Library at Yale University and has the identifying number Art Store 1980.157. For discussion of the map see Alexander O. Vietor, "A Pre-Columbian Map of the World, Circa 1489," Imago Mundi 17 (1963), pp. 95-96; Marcel Destombes, Mappemondes, A.D. 1200-1500 (Amsterdam: N. Israel, 1964), pp. 229-233 with plates 37-38; Carlos Sanz, "Un mapa del mundo verdaderamente importante en la famosa Universidad de Yale," Boletín de la Real Sociedad Geográfica 102 (1966), pp. 7-46; Arthur Davies, "Behaim, Martellus and Columbus," Geographical Journal 143 (1977), pp. 450-59, esp. 456-58; and Ilaria Luzzana Caraci, "Il Planisfero di Enrico Martello della Yale University Library e i Fratelli Colombo," Rivista Geografica Italiana 75 (1978), pp.132-43, translated into English as "Henricus Martellus' Map in the Yale University Library and the Columbus Brothers" in the author's The Puzzling Hero: Studies on Christopher Columbus and the Culture of His Age (Rome: Carocci, 2002), pp. 281-291.

${ }^{30}$ On Waldseemüller's borrowing of the descriptive texts on his 1507 map from Martellus see note 12 above.

${ }^{31}$ For good general accounts of nautical charts see Tony Campbell, "Portolan Charts from the Late Thirteenth Century to 1500," in J. B. Harley and David Woodward, eds., The History of Cartography (Chicago: University of Chicago Press, 1987-), vol. 1, pp. 371-463; Corradino Astengo, "The Renaissance Chart Tradition in the Mediterranean," in David Woodward, ed., The History of Cartography, vol. 3.1: Cartography in the European Renaissance (Chicago and London: The University of Chicago Press, 2007), pp. 174-262; and Ramon J. Pujades i Bataller, Les cartes portolanes: la representació medieval d'una mar solcada (Barcelona: Institut Cartogràfic de Catalunya, 2007), with CD.
} 


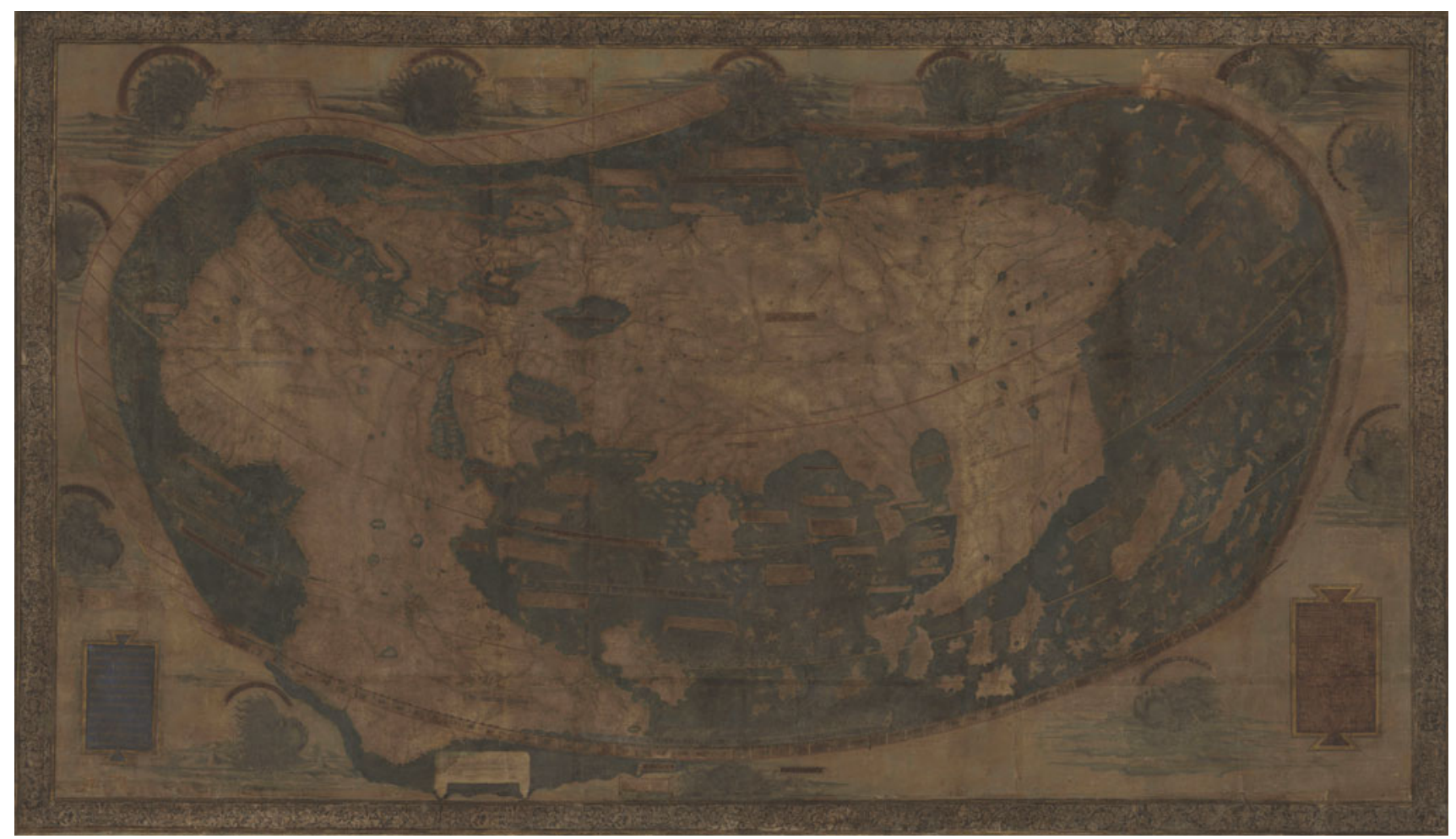

Fig. 1.1 World map made by Henricus Martellus c. 1491. Beinecke Rare Book and Manuscript Library, Art Store 1980.157. Image by Lazarus Project/MegaVision/RIT/EMEL, courtesy of the Beinecke Rare Book and Manuscript Library

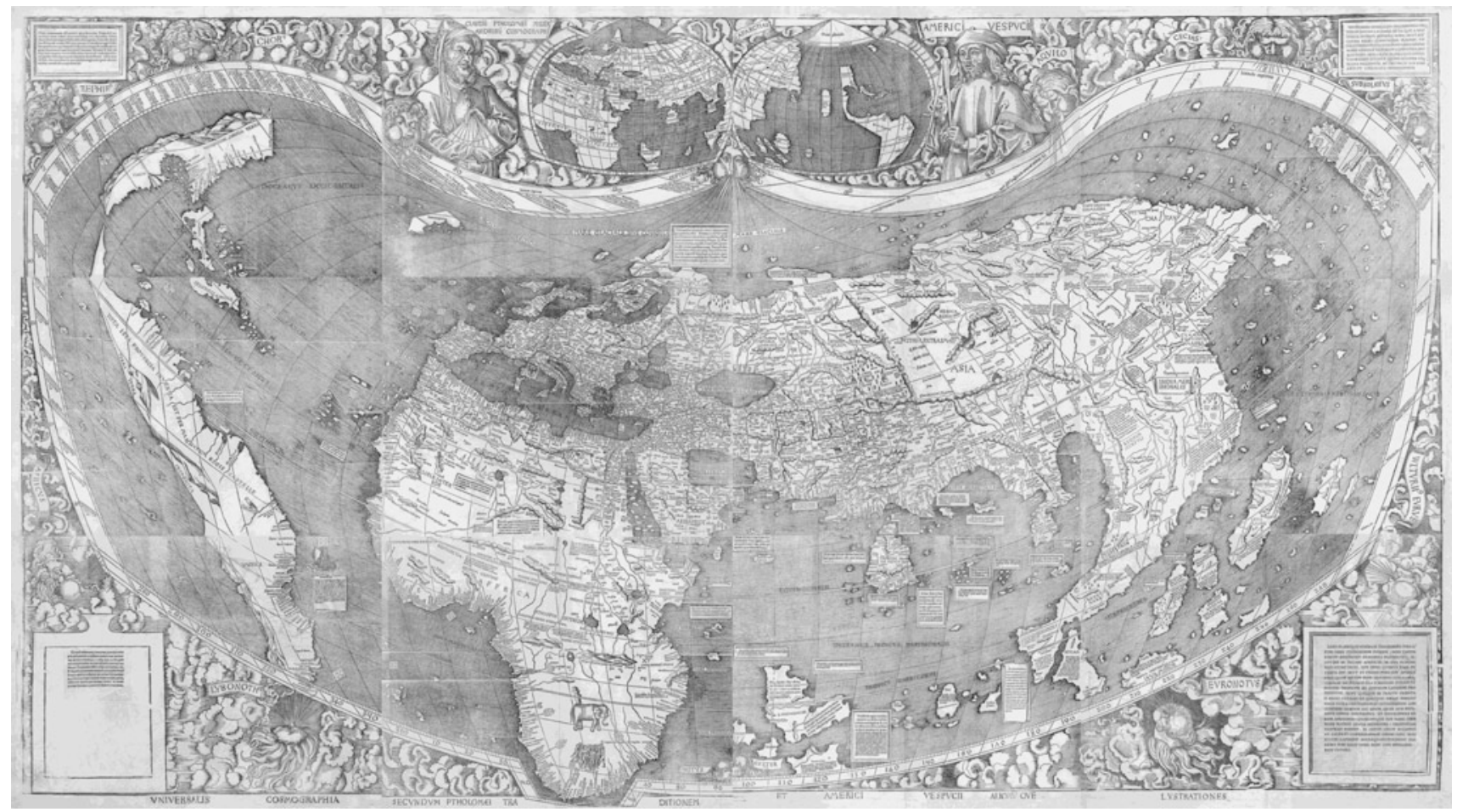

Fig. 1.2 Martin Waldseemüller's world map of 1507. Library of Congress, Geography and Map Division, G3200 1507 .W3. Courtesy of the Library of Congress 


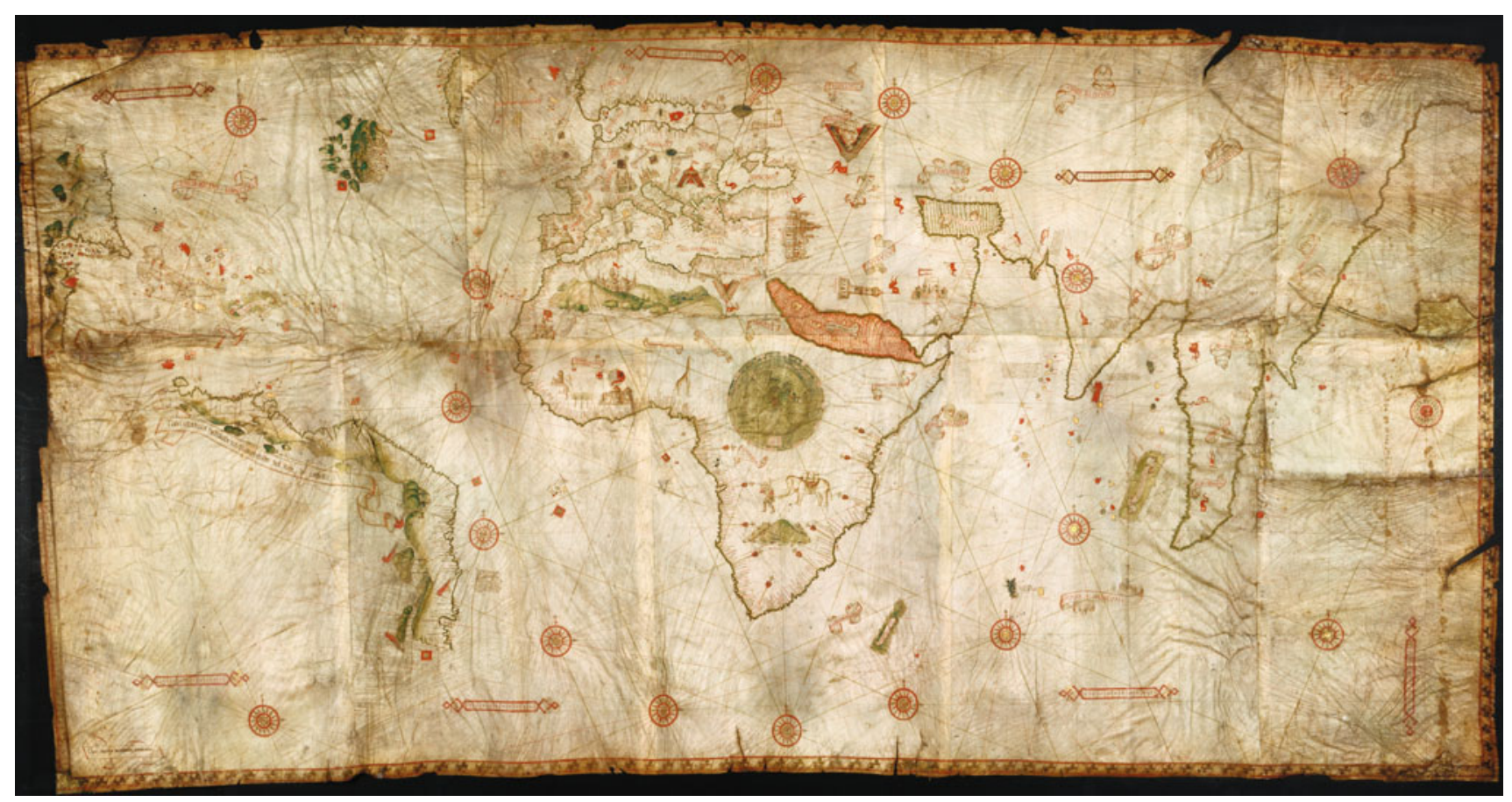

Fig. 1.3 Nautical chart by Nicolo de Caverio, c. 1503 (Paris, Bibliothèque nationale de France, Cartes et plans, SH archives 1). Courtesy of the Bibliothèque nationale de France

century. In essence they are practical tools for navigation, usually hand-drawn on parchment, with the emphasis on coastal features and place names; rather than being marked with latitude and longitude, they have a system of rhumb lines that radiate out in the standard compass directions (or directions of the traditional winds) from points organized in one or two large circles. In addition to the relatively plain nautical charts used for navigation, others were elaborately decorated with cities, kings, animals, flags, and compass roses, and had descriptive texts added to them. This was the type of map that Waldseemüller chose as the model for his 1516 map, and in fact we know the specific map he used: the nautical chart by Nicolo de Caverio of Genoa, made c. 1503 (Fig. 1.3). ${ }^{32}$ We know this because of the close similarities of place names between Caverio's chart and Waldseemüller's Carta marina, ${ }^{33}$ and the striking similarities of layout between the two maps (Fig. 1.4), including the area of the world depicted and the locations of the nodes of the systems of rhumb lines.

What caused Waldseemüller to abandon the Ptolemaic model and projection he had used in his 1507 map and adopt a nautical chart model — and to abandon the bold idea he had implemented in his 1507 map of depicting the whole circumference of the earth $?^{34}$ The former question is particularly intriguing, as we know that Waldseemüller had access to the Caverio map when he made his 1507 map. ${ }^{35}$ Yet he still chose to use Ptolemy's system of cartography rather than the nautical chart system, and also to use Ptolemy's information for the shape of North Africa, for example, while the shape of

\footnotetext{
${ }^{32}$ The Caverio chart is in Paris, Bibliothèque nationale de France, Cartes et plans, SH archives 1, and measures $115 \times 225 \mathrm{~cm}$, similar in size to Waldseemüller's maps of 1507 and 1516. Edward L. Stevenson has studied the map in Marine World Chart of Nicolo de Caneiro Januensis 1502 ( circa) (New York: American Geographical Society and the Hispanic Society of America, 1908). The longer legends on the map are transcribed by Armando Cortesão, Cartografia e cartógrafos portugueses dos séculos XV e XVI (Lisbon: Seara Nova, 1935), vol. 1, pp. 154-155. There is a color facsimile, which is smaller, however, than the original: Planisphère nautique sur vélin du Génois Nicolao de Caverio (Paris: Bibliothèque nationale, 1992). For discussion of the map in addition to that in Stevenson's work see L. Gallois, "Le Portulan de Nicolas de Canerio," Bulletin de la Société de Géographie de Lyon 9 (1890), pp. 97-119, reprinted in Acta Cartographica 9 (1970), pp. 76-98.

${ }^{33}$ For tables comparing the place names on Caverio's map and Waldseemüller's Carta marina for the New World and the coast of Africa see Stevenson, Marine World Chart (see note 32), pp. 84-110.

${ }^{34}$ Waldseemüller's boldness in depicting all $360^{\circ}$ of the earth's circumference on the 1507 map is emphasized by the accompaniment of that map with a small globe based on the same geography as the map.

${ }^{35}$ For a list of some of the place names that are similar in the Caverio chart and Waldseemüller's 1507 map—including the copying of errors—see Joseph Fischer and Franz Ritter von Wieser, Die älteste Karte mit dem Namen Amerika (see note 9), pp. 26-29.
} 


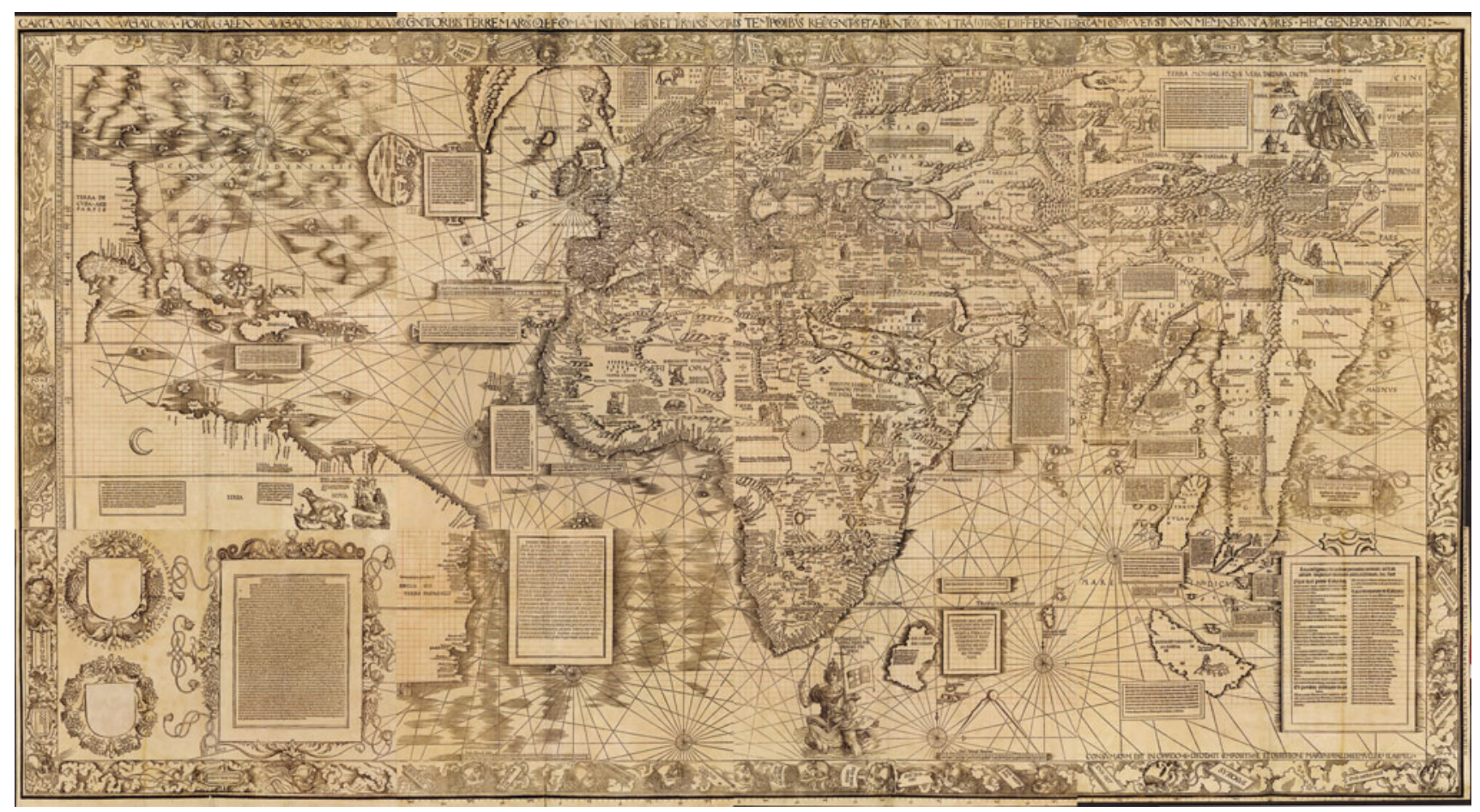

Fig. 1.4 Martin Waldseemüller's Carta marina of 1516. Library of Congress, Geography and Map Division, G1015 .S43 1517 Vault. Courtesy of the Library of Congress

that same region is markedly different (and more accurate) on Caverio's chart. Evidently at some point between 1507 and 1516, perhaps while he was involved in the production of the 1513 edition of Ptolemy's Geography, he became convinced of the superiority of the more recent geographical data available in nautical charts. I will explore this question, and the development of Waldseemüller's cartographic thought, in more detail below, but certainly one factor in his decision to follow the nautical chart model was that the best data available was already in that format.

With regard to the latter question, namely why Waldseemüller chose not to depict the whole circumference of the earth in his Carta marina, although Waldseemüller clearly decided to be less venturous in depicting little-known regions, the answer cannot be simply that he did not have good data about the parts of the world he does not depict on the Carta marina. One notable difference between Caverio's map and the Carta marina is that Waldseemüller depicts less of the eastern part of the world than his model: Caverio shows substantial portions of the northeastern coast of continental Asia and of the ocean we now call the Pacific that Waldseemüller chose not to copy (compare Figs. 1.3 and 1.4). Waldseemüller had reasonably good information about the location of Japan from reading Marco Polo's account of his travels, who placed Japan 1500 miles east of mainland China, ${ }^{36}$ and Waldseemüller depicted it on his 1507 map, but not on his Carta marina. The answer seems to be that Waldseemüller designed the Carta marina to be more practical than his 1507 map: it shows only the parts of the world where Europeans had traveled, and where trade was known to occur, and it shows those parts using a fundamentally practical cartographic format, one developed for use on ships.

In addition to omitting some 128 degrees of longitude from the Carta marina, Waldseemüller depicts much less of the northern polar regions: his 1507 map runs all the way to the North Pole, but the Carta marina only to a bit more than $70^{\circ} \mathrm{N}$. The Carta marina does include several more degrees of latitude in the southern ocean than the 1507 map, but overall, Waldseemüller's exclusion of large parts of the earth's surface from the Carta marina, together with the Carta marina being almost exactly the same physical size as the 1507 map, and its border being much narrower, meant that Waldseemüller was able to show far more detail, including both texts and images, in the areas that he does depict than he could on the 1507

\footnotetext{
${ }^{36}$ For the distance of Cipangu or Japan from mainland Asia see Marco Polo, Marka Pavlova z Benátek, Milion: Dle jediného rukopisu spolu s prilusnym zakladem latinskym, ed. Justin Václav Prásek (Prague: Nákl. Ceské akademie císare Frantiska Iozefa, 1902), p. 153; and Marco Polo, The Book of Ser Marco Polo, ed. and trans. Henry Yule (New York: C. Scribner's Sons, 1903), Book 3, Chap. 2, vol. 2, p. 253.
} 
map. In comparison with the 1507 map, the Carta marina offers a "zoomed in" view of the known parts of the world. Thus, for example, in Arabia on sheet 6 of the 1507 map, there is room only for place names from Ptolemy and indications of mountains and rivers, but on the Carta marina there are images of Mecca and Medina as well as long legends describing the cities and features of the region (see Legends 7.6, 7.8, and 7.9).

One of the most striking differences between Waldseemüller's Carta marina and its principal model, the Caverio chart, is in the interiors of the continents, particularly in Africa and Asia. On Caverio's chart the emphasis (as is common on nautical charts) is on the coastlines, and he provides very few geographical details of the interior. In Africa there are images of two mountain ranges, three cities and three animals, some banners indicating the names of regions, and a decorative circular world map in place of a compass rose. Asia is largely empty, aside from some compass roses and a few banners with place names. The situation on the Carta marina is entirely different: both Africa and Asia are full of rivers, mountains, images of cities, sovereigns, peoples and animals, as well as descriptive texts. Waldseemüller also takes advantage of the open spaces in the unknown interior of South America and in the southern ocean to supply long texts, one the long introduction to the map quoted from earlier, another describing South America, and in the southeastern corner of the map (Legend 12.11), a list of the sources and prices of the spices in the great trading center of Calicut (now Kozhikode, India).

The abundance of geographical information and texts on the Carta marina should be considered from a few different perspectives. First, the advent of printed maps represented a great democratization of cartography, so that the information in a very expensive manuscript map like Caverio's could be made available to many people through the printing press at a much lower cost. ${ }^{37}$ What Waldseemüller chose to democratize, however, was not just Caverio's chart, but a richer, more detailed, and more edifying version of the chart, with many more decorative elements and much more textual information. A number of manuscript nautical charts have a similar high level of expensive optional elements, including images and descriptive texts, such as the Catalan Atlas of $1375^{38}$ and Mecia de Viladestes's nautical chart of $1413{ }^{39}$ but Waldseemüller's Carta marina is the first large printed nautical chart, and it matches or exceeds these particularly elaborate nautical charts in the amount of information it offers.

It is also possible that the large amount of text on the Carta marina, particularly the long introduction in the lower left corner, was intended to render a booklet to accompany the map unnecessary: Waldseemüller and his colleague Matthias Ringmann had accompanied the 1507 world map with the booklet titled Cosmographiae introductio, and the 1511 wall map of Europe with the booklet Instructio manuductionem prestans in cartam itinerariam Martini Hilacomili. ${ }^{40}$ We cannot be certain about this surmise, however, as Lorenz Fries's later German-language version of the Carta marina was accompanied by a booklet titled Uslegung der mercarthen oder Charta marina (Explanation of the Sea Map or Carta marina), which was probably written in part from Waldseemüller's notes for his unfinished Chronica mundi or Itineraria. ${ }^{41}$

\subsection{Waldseemüller's Textual Sources on the Carta Marina}

Waldseemüller's 1507 map, like his Carta marina, has a large number of descriptive texts, particularly in Africa and Asia, but one of the most remarkable things about the texts on the Carta marina is that the overwhelming majority of them are different from the ones on the earlier map. Waldseemüller abandoned not only his earlier cartographic model (i.e. Ptolemy, by way of Martellus), but also most of his earlier textual sources, in order to create an entirely new and modern image of the world. This must have been exciting but also time-consuming, carefully studying various texts looking for just the right passages to explain different regions or cities or peoples, and also for clues about the relative locations of those places.

\footnotetext{
${ }^{37}$ We do not know the sale price of either of Waldseemüller's large world maps, but according to a letter dated 26 February 1525 , from Hans Grüninger to the Nurnberg printer and publisher Anton Koberger, a copy of Lorenz Fries's 1525 version of Waldseemüller's Carta marina was worth 5 florins. See Oskar von Hase, Die Koberger: Eine Darstellung des buchhändlerischen Geschäftsbetriebes in der Zeit des Überganges vom Mittelalter zur Neuzeit (Leipzig: Breitkopf \& Härtel, 1885), p. cxxxviii, document 116.

${ }^{38}$ The Catalan Atlas is in Paris, Bibliothèque nationale de France, MS Espagnol 30; the map has been reproduced in facsimile a few times, including Mapamundi del año 1375 (Barcelona: S.A. Ebrisa, 1983), and more recently El món i els dies: L'Atles Català (Barcelona: Enciclopèdia Catalana, 2005). The atlas is also reproduced in Pujades, Les cartes portolanes (see note 31), on the accompanying CD, number C16.

${ }^{39}$ The chart by Mecia de Viladestes is in Paris, Bibliothèque nationale de France, Rés. Ge AA 566; it is illustrated in Michel Mollat and Monique de la Roncière, Sea Charts of the Early Explorers: 13th to 17th Century, trans. L. le R. Dethan (New York: Thames and Hudson, 1984), chart 12; and Pujades, Les cartes portolanes (see note 31), pp. 202-203, and on the accompanying CD, number C30.

${ }^{40}$ On the Cosmographiae introductio see note 7 above, and on the Instructio manuductionem prestans see note 15.

${ }^{41}$ On these unfinished works by Waldseemüller see note 21 above.
} 
Waldseemüller lists his textual sources in the long legend in the lower left corner of the map (Legend 9.3); here follows the list, rearranged chronologically by the dates of the authors:

- Giovanni da Pian del Carpine, or John of Plano Carpini (c. 1182-1252), who as papal legate traveled via a northern route to the Great Khan in China, by way of Russia and Mongolia. Manuscripts of Carpini's travel narrative, which exists in two redactions, and are titled either Ystoria Mongalorum or Liber Tartarorum, are rare, and the whole of the Historia Mongalorum was not published until the nineteenth century. ${ }^{42}$ Waldseemüller almost certainly consulted his travel narrative via the excerpts that Vincent of Beauvais (c. 1190-c. 1264) incorporated into Book 32 of his Speculum historiale, which exists in many manuscript copies and was first printed in $1473 .^{43}$

- Friar Ascelinus, who was part of a group of Dominicans who visited the encampment of the Mongol prince Baiju in 1247. Simon of Saint Quentin, who traveled with Ascelinus, wrote an account of this mission, ${ }^{44}$ and excerpts of his narrative (like the excerpts from Plano Carpini's account) were included in Book 32 of Beauvais's Speculum historiale. ${ }^{45}$

- Marco Polo (c. 1254-1324), the famous Venetian traveler who spent twenty-four years in the East, and whose account of his travels includes descriptions of places in the Middle East, Central Asia, China, and the Indian Ocean. Marco Polo's text exists in many manuscripts, translations, and editions; the first Latin edition was printed by Gheraert Leeu in approximately $1484 .{ }^{46}$ Waldseemüller made heavy use of Marco Polo in his 1507 map, mostly through borrowings from a large world map by Henricus Martellus. He makes dramatically less use of the Venetian author's work in his Carta marina: instead of copying descriptive texts from Martellus's map, Waldseemüller searched out his own descriptive texts in a variety of geographical texts and travel narratives.

- Odorico of Pordenone (c. 1286-1331), an Italian missionary and diplomat who traveled from Venice across the Middle East to India, visited some islands in the Indian Ocean, and spent three years in China. His account of his journey was first published in Pesaro in 1513, under the title Odorichus de rebus incognitis (Odoric on Unknown Things) (despite the Latin title, the text is in Italian), ${ }^{47}$ but was also available in manuscripts. ${ }^{48}$

\footnotetext{
${ }^{42}$ See M. A. P. d'Avezac, ed., "Johannis de Plano Carpini Antivariensis Archiepiscopi Historia Mongalorum quos nos Tartaros appellamus," Recueil de Voyages et de Mémoires 4 (1839), pp. 603-779. The standard edition is Giovanni da Pian del Carpine, Storia dei Mongoli, ed. Enrico Menestò and trans. Maria Cristiana Lungarotti (Spoleto: Centro italiano di studi sull'alto Medioevo, 1989), which includes an Italian translation and a map of Plano Carpini's travels in plate 2 following p. 224.

${ }^{43}$ See C. Raymond Beazley, ed., The Texts and Versions of John de Plano Carpini and William de Rubruquis (London: The Hakluyt Society, 1903); and Gregory G. Guzman, "The Encyclopedist Vincent of Beauvais and His Mongol Extracts from John of Plano Carpini and Simon of Saint-Quentin," Speculum 49.2 (1974), pp. 287-307. The 1473 edition of the Speculum historiale was printed in Strasbourg, probably by Adolf Rusch, in four volumes. In the edition Bibliotheca mvndi. Vincentii burgvndi ... Specvlvm qvadrvplex, natvrale, doctrinale, morale, historiale (Douai: Baltazaris Belleri, 1624), which is readily available through its facsimile reprinting with the title Speculum quadruplex; sive, Speculum maius (Graz: Akademische Druck-u. Verlaganstalt, 1964-66), the material in question appears in Book 31 of the Speculum historiale (which is vol. 4 of the set), rather than in Book 32.

${ }^{44}$ The Latin text of Simon's account has been published as Simon de Saint-Quentin, Histoire des Tartares, ed. Jean Richard (Paris: P. Geuthner, 1965); it was translated into French in Pierre Bergeron, ed., Voyages de Benjamin de Tudelle autour du monde, commencé l'an 1173, de Jean du Plan Carpin en Tartarie, du frère Ascelin et de ses compagnons vers la Tartarie, de Guillaume de Rubruquin en Tartarie et en Chine en 1253, suivis des additions de Vincent de Beauvais et de l'histoire de Guillaume de Nangis pour l'éclaircissement des précédents voyages (Paris: Imprimé aux frais du gouvernement pour procurer du travail aux ouvriers typographes, 1830), pp. 215-235.

${ }^{45}$ On Ascelinus see Igor de Rachewiltz, Papal Envoys to the Great Khans (Stanford, Calif.: Stanford University Press, 1971), pp. 115-119. A more detailed but diffuse account is in Paul Pelliot, "Les Mongols et la Papauté," Revue de l'Orient chrétien 23 (1922-23), pp. 3-30; 24 (1924), pp. 225-335; and 28 (1931-32), pp. 3-84, esp. 24 (1924), pp. 262-335. On Simon of Saint Quentin's account see Gregory G. Guzman, "Simon of Saint-Quentin and the Dominican Mission to the Mongols, 1245-1248," Ph.D. Dissertation, University of Cincinnati, 1968; and the same author's "Simon of Saint-Quentin and the Dominican Mission to the Mongol Baiju: A Reappraisal," Speculum 46.2 (1971), pp. $232-249$.

${ }^{46}$ On this first Latin edition of Marco Polo see Lotte Hellinga, "Marco Polo's Description of the Far East and the Edition Printed by Gheraert Leeu," in Elly Cockx-Indestege, ed., E codicibus impressisque: opstellen over het boek in de Lage Landen voor Elly Cockx-Indestege (Louvain: Peeters, 2004), vol. 1, pp. 309-328. For discussion of the Latin manuscripts of Polo see Consuelo Wager Dutschke, "Francesco Pipino and the Manuscripts of Marco Polo's Travels," Ph.D. Dissertation, University of California at Los Angeles, 1993. For an account of manuscripts and editions (including those not in Latin) of Polo see Marco Polo, The Description of the World, trans. and ed. A. C. Moule and Paul Pelliot (London: G. Routledge, 1938), vol. 1, pp. 509-519.

${ }^{47}$ The Latin and Italian text of Odoric and an English translation are provided by Henry Yule, ed. and trans., Cathay and the Way Thither: Being a Collection of Medieval Notices of China, revised by Henri Cordier (London: The Hakluyt Society, 1913-16), vol. 2.

${ }^{48}$ For a bibliography on manuscripts of Odoric's narrative see Marianne O’Doherty, "The Viaggio in Inghilterra of a Viaggio in Oriente: Odorico da Pordenone's Itinerarium from Italy to England,” Italian Studies 64.2 (2009), pp. 198-220, esp. 200.
} 
- Pierre d'Ailly (1351-1420), a French cardinal, theologian and cosmographer whose Imago mundi (Image of the World) is well known for having influenced Christopher Columbus's geographical thought, specifically his conception of the width of the Atlantic ${ }^{49}$ : Columbus owned a copy of the book which he heavily annotated. ${ }^{50}$ The work survives in several manuscripts,${ }^{51}$ and it was first published c. $1480-1483 .{ }^{52}$

- Alvise Cadamosto (c. 1432-1483), a Venetian merchant and navigator who explored the western coast of Africa for Portugal in 1455 and $1456 .{ }^{53}$ Cadamosto's Navigazioni were first published as Chaps. 1-47 of Paesi novamente retrovati (Newly Discovered Countries), an important collection of travel narratives first published in 1507 that was quickly translated into Latin and German. ${ }^{54}$ The Paesi was in fact the second most frequently printed early account of the discoveries in the New World, after Vespucci's Mundus novus. ${ }^{55}$ The interest of Waldseemüller or his associates in the voyage of Cadamosto is indicated by the existence of proof sheets of maps from Waldseemüller's workshop that show the course Cadamosto took down the coast of Africa. ${ }^{56}$

- Caspar the Jew of India, also called Gaspar de Gama (1444-c. 1510-1520), a Jewish merchant who met Vasco da Gama in India and acted as an interpreter for da Gama and other Portuguese navigators. ${ }^{57}$ Material from Caspar was transmitted

${ }^{49}$ On d'Ailly's Imago mundi see Jeannine Quillet, "L'Imago Mundi de Pierre d'Ailly," in Danielle Buschinger and Wolfgang Spiewok, eds., Nouveaux mondes et mondes nouveaux au Moyen Age: Actes du Colloque du Centre d'Etudes Médiévales de l'Université de Picardie Jules Verne, Amiens, mars 1992 (Greifswald: Reineke Verlag, 1994), pp. 107-114; for discussion of his other works as well see Jean-Patrice Boudet, "Un prélat et son équipe de travail à la fin du Moyen Âge: remarques sur l'oeuvre scientifique de Pierre d'Ailly," in Didier Marcotte, ed., Humanisme et culture géographique à l'époque du Concile de Constance: autour de Guillaume Fillastre: Actes du colloque de l'Université de Reims, 18-19 novembre 1999 (Turnhout: Brepols, 2002), pp. 127-150.

${ }^{50}$ The copy of d'Ailly's Imago mundi annotated by Columbus, which is in the Biblioteca Colombina in Seville, has been reproduced in facsimile as Pierre d'Ailly, Imago mundi (Madrid: Testimonio Compañía Editorial, 1990), with a volume of commentary by Juan Pérez de Tudela, and a translation of d'Ailly into Spanish by Antonio Ramírez de Verger. Also see George E. Nunn, "The Imago Mundi and Columbus," American Historical Review 40.4 (1935), pp. 646-661; and Elisabetta Sarmati, "Le postille di Colombo all'Imago Mundi di Pierre d'Ailly," Columbeis 4 (1990), pp. 23-42.

${ }^{51}$ For manuscripts of d'Ailly's work see Destombes, Mappemondes (see note 29), pp. 161-163.

${ }^{52}$ The standard modern edition of d'Ailly's work, which includes the Latin text and a French translation, is Pierre d'Ailly, Ymago mundi, ed. Edmond Buron (Paris: Maisonneuve frères, 1930).

${ }^{53}$ Gerald R. Crone, ed. and trans., The Voyages of Cadamosto and Other Documents on Western Africa in the Second Half of the Fifteenth Century (London: Printed for the Hakluyt Society, 1937).

${ }^{54}$ The full title of the book is Paesi nouamente retrouati et Nouo Mondo da Alberico Vesputio Florentino intitulato (Vicenza: Henrico Vicentino, 1507). For a brief discussion of the 1507 edition of the Paesi novamente retrovati see Henry Harrisse, Bibliotheca Americana Vetustissima: A Description of Works Relating to America, Published Between the Years 1492 and 1551 (New York: G. P. Philes, 1866), no. 48, pp. 96d-99; and António Alberto Banha de Andrade, Mundos novos do mundo: panorama da difusão, pela Europa, de notícias dos descobrimentos geográficos portugueses (Lisbon: Junta de Investigações do Ultramar, 1972), vol. 1, pp. 527-532. The most detailed account of the Paesi in English is in Antony Vallavanthara, India in 1500 A.D.: The Narratives of Joseph the Indian (Mannanam: Research Institute for Studies in History, 1984), pp. 11-24 and 295-311. Vallavanthara discusses the Latin translation of the Paesi, the Itinerarium Portugallensium, on pp. 24-41 and 312-315. There is a detailed discussion of the work's contents in Norbert Ankenbauer, 'Das ich mochte meer newer dyng erfaren': die Versprachlichung des Neuen in den 'Paesi novamente retrovati' (Vicenza, 1507) und in ihrer deutschen Übersetzung (Nürnberg, 1508) (Berlin: Frank \& Timme, 2010), esp. pp. 51-123. The most readily available printed edition of the Paesi is a facsimile of the 1508 edition, published in Vespucci Reprints, Texts and Studies (Princeton, N.J.: Princeton University Press, 1916), vol. 6, under the title Paesi nouamente retrovati \& Novo mondo da Alberico Vesputio Florentino intitulato. Better still, Norbert Ankenbauer has made a digital edition of the 1507 edition and also of the 1508 German translation of the book, available at http://diglib.hab.de/edoc/ed000145/start.htm. The manuscript that served as the basis of the printed edition of the Paesi novamente retrovati, known as the Trevisan Manuscript, resides at the Library of Congress with the shelfmark MSS Med. \& Ren., 26; for discussion see Eric Dursteler, "Reverberations of the Voyages of Discovery in Venice, ca. 1501: The Trevisan Manuscript in the Library of Congress," Mediterranean Studies 9 (2000), pp. 43-64. The documents associated with the manuscript at the Library of Congress include a copy of the following thesis, which in vol. 2 has a complete transcription of the manuscript: Fredi Chiappelli, "La relazione di Angelo Trevisan sui primi viaggi di Cristoforo Colombo," Mémoire de Licence, Université de Lausanne, 1968.

${ }^{55}$ See Rudolf Hirsch, "Printed Reports on the Early Discoveries and Their Reception," in Fredi Chiappelli, Michael J. B. Allen, and Robert Louis Benson, eds., First Images of America: The Impact of the New World on the Old (Berkeley: University of California Press, 1976), vol. 2, pp. 537551 , at 546.

${ }^{56}$ See Peter H. Meurer, "Sechs Karten der westafrikanischen Küste aus der Waldseemüller-Schule,” Cartographica Helvetica 45 (2012), pp. 1526; the maps are in a copy of the Itinerarium Portugallensium in Vienna, Österreichische Nationalbibliothek, shelfmark 394.092-C.Kar. There is an earlier discussion of the same maps in Erich Woldan, "Die altesten gedruckten modernen Karten Afrikas," Anzeiger der PhilosophischHistorischer Klasse der Osterreichischen Akademie der Wissenschaften 118 (1981), pp. 252-257.

${ }^{57}$ On Gaspar see E. G. Ravenstein, ed., A Journal of the First Voyage of Vasco da Gama, 1497-1499 (London: Printed for the Hakluyt Society, 1898), pp. 179-180; Franz Hümmerich, "Studien zum 'Roteiro' der Entdeckungsfahrt Vascos da Gama 1497-1499," Revista da Universidade de Coimbra 10 (1927), pp. 53-302, esp. 93-137; Elias Lipiner, Gaspar da Gama: um converso na frota de Cabral (Rio de Janeiro, RJ: Editora Nova Fronteira, 1987); and Stefania Elena Carnemolla, "Un certo Gaspar da Gama: sfuggente figura di 'interprete' dei viaggiatori portoghesi del Cinquecento," in Maria José de Lancastre, Silvano Peloso, and Ugo Serani, eds., E vós, tágides minhas: miscellanea in onore di Luciana Stegagno Picchio (Viareggio, Lucca: M. Baroni, 1999), pp. 229-240; reprinted in L'Erasmo 16 (2003), pp. 59-74. 
in a letter by Girolamo Sernigi included in Paesi novamente retrovati, Chaps. 60-62. ${ }^{58}$ This book was among Waldseemüller's most important sources, but Caspar is not identified by name in those passages, and Waldseemüller seems not to have made use of those chapters, as he had a superior version of Caspar's account. In the text block on sheet 9 of the Carta marina (see Legend 9.3) Waldseemüller says that he had access to a travel narrative by Caspar that was sent to the King of Portugal, but that document does not appear to have survived.

- Francisco de Almeida (c. 1450-1510), ${ }^{59}$ a Portuguese nobleman, soldier and explorer who was essential in the establishment of Portuguese power in the Indian Ocean. ${ }^{60}$ On Almeida's voyage of 1505 from Portugal to India, one of the passengers was Balthasar Springer, or Sprenger, the representative of a trading company in Augsburg, Germany. Springer wrote an account of the voyage, which is the work that Waldseemüller is really citing. ${ }^{61}$ The first edition of Springer's narrative, which was published in German in $1509,{ }^{62}$ was illustrated by Hans Burgkmair. ${ }^{63}$ Waldseemüller made relatively little use of it, just for some toponyms in India and an image of an Indian man and an African man.

- Christopher Columbus (1451-1506), the famous Genoese explorer. Peter Martyr d'Anghiera began writing an account of the discovery of the New World in $1494,{ }^{64}$ and in 1504 some chapters from his work that give an account of Columbus's first three voyages were translated into Italian and published in the now very rare Libretto de tutta la nauigatione de Re de Spagna de le isole et terreni nouamente trouati ${ }^{65}$; this material was incorporated into the Paesi novamente retrovati a few years later in 1507 (Chaps. 84-108), which is where Waldseemüller may have found it.

- Pedro Álvares Cabral (c. 1467-c. 1520), the Portuguese explorer who in 1500-1501 discovered Brazil, sailed on to India, and then returned to Portugal. ${ }^{66}$ One of the earliest and most complete accounts of Cabral's voyage was written by an

\footnotetext{
${ }^{58}$ The letter with material from Gaspar is translated into English in Ravenstein, A Journal of the First Voyage (see note 57), pp. 137-141, with an introduction on pp. 119-123.

${ }^{59}$ Banha de Andrade, Mundos novos do mundo (see note 54), vol. 2, p. 580, suggests that the authority Waldseemüller is citing is actually Francisco de Albuquerque, and that Waldseemüller was using manuscript letters of his, but this seems doubtful: there are really no similarities between the narrative about to be cited and Waldseemüller's legends. For discussion of Francisco de Albuquerque see Jean Aubin, "Francisco de Albuquerque, un juif castillan au service de l'Inde Portugaise (1510-15)," Arquivos do Centro Cultural Português 7 (1974), pp. 175-188.

${ }^{60}$ For an account of Almeida's life see Joaquim Candeias Silva, O Fundador do 'Estado Português da Índia' D. Francisco de Almeida, 1457(?)1510 (Lisbon: Imprensa Nacional, 1996). There is a portrait of Franciso de Almeida in New York, Pierpont Morgan Library, MS M. 525, f. 4r, the Livro de Lisuarte de Abreu of c. 1558, which has been reproduced in facsimile as Livro de Lisuarte de Abreu (Lisbon: Comissão Nacional para as Comemorações dos Descobrimentos Portugueses, 1992).

${ }^{61}$ For discussion of the Almeida/ Springer voyage see Franz Hümmerich, "Quellen und Untersuchungen zur Fahrt der ersten Deutschen nach dem portugiesischen Indien 1505/6," Abhandlungen der Königlich Bayerischen Akademie der Wissenschaften, Philosophisch-philologische und historische Klasse 30.3 (1918), pp. 1-153; and Thomas Horst, "The Voyage of the Bavarian Explorer Balthasar Sprenger to India (1505/1506) at the Turning Point between the Middle Ages and Early Modern Times: His Travelogue and the Contemporary Cartography as Historical Sources," in Philipp Billion, Nathanael Busch, Dagmar Schlüter, and Zenia Stolzenburg, eds., Weltbilder im Mittelalter = Perceptions of the World in the Middle Ages (Bonn: Bernstein-Verlag, 2009), pp. 167-197.

${ }^{62}$ Balthasar Springer, Die Merfart vn[d] erfarung nüwer Schiffung vnd Wege zu viln onerkanten Jnseln vnd Künigreichen von dem großmechtigen Portugalische[n] Kunig Emanuel Erforscht funden bestritten vnnd Jngenomen ([Oppenheim]: [Köbel], 1509). For an English translation see Balthasar Springer, The Voyage from Lisbon to India, 1505-6: Being an Account and Journal, ed. C. H. Coote (London: B. F. Stevens, 1894). Note that the work is misattributed to Vespucci in this edition.

${ }^{63}$ On Burgkmair's illustrations of Springer's narrative see Jean Michel Massing, "Hans Burgkmair's Depiction of Native Africans," RES: Anthropology and Aesthetics 27 (1995), pp. 39-51. As Massing notes on p. 39, "Burgkmair's woodcuts... were, for decades, the only representations of Africans and Indians based on visual information rather than mere literary testimony." Also see Stephanie Leitch, "Burgkmair's Peoples of Africa and India (1508) and the Origins of Ethnography in Print," The Art Bulletin 91.2 (2009), pp. 134-159; and Sandra Young. "Envisioning the Peoples of 'New' Worlds: Early Modern Woodcut Images and the Inscription of Human Difference," English Studies in Africa 57.1 (2014), pp. 33-54.

${ }^{64}$ On Peter Martyr's writings about the New World and Columbus see John Boyd Thacher, Christopher Columbus: His Life, His Work, His Remains as Revealed by Original Printed and Manuscript Records (New York and London: G.P. Putnam's Sons: The Knickerbocker Press, 1903-1904), vol.1.1, pp. 3-110; David Beers Quinn, "New Geographical Horizons: Literature," in Fredi Chiappelli, Michael J. B. Allen, and Robert Louis Benson, eds., First Images of America: The Impact of the New World on the Old (Berkeley: University of California Press, 1976), vol. 2, pp. 635-658, esp. 647-651; and Juan Gil, "Pedro Mártir de Anglería, intérprete de la cosmografía colombina," Anuario de Estudios Americanos 39 (1982), pp. $487-502$.

${ }^{65}$ Chapters 22 to 25 of the Libretto, which contain the description of Columbus's First Voyage, are transcribed in Guglielmo Berchet, Fonti italiane per la storia della scoperta del Nuovo mondo, in Raccolta di documenti e studi pubblicati dalla R. Commissione colombiana (Rome: Ministero della pubblica istruzione, 1892-1896), part 3, vols. 1-2, in vol. 2, pp. 173-177. For an introduction to the Libretto, facsimile, and English translation see Thacher, Christopher Columbus (see note 64), vol. 2, pp. 438-456, 457-485, and 486-514, respectively. There is also a later facsimile of the copy in the John Carter Brown Library: Pietro Martire d'Anghiera, Libretto de tutta la nauigatione de re de Spagna de la isole et terreni nouamente trouati, Venice, 1504, ed. Lawrence Wroth (Paris: H. Champion, 1929); and a Spanish translation in Marisa Vannini de Gerulewicz, El Mar de los descubridores: documentos y relatos inéditos o poco conocidos sobre el descubrimiento y la exploración de los mares, islas y tierras del Nuevo Mundo (siglos XV-XVI) (Caracas: Comisión Organizadora de la III Conferencia de las Naciones Unidas sobre Derecho del Mar, 1974), pp. 111-158. ${ }^{66}$ On Cabral's voyage see Max Justo Guedes, ed., A viagem de Pedro Alvares Cabral e o descobrimento do Brasil, 1500-1501 (Lisbon: Academia de Marinha, 2003), and the references cited in the following note.
} 
unnamed member of the fleet and is known as the "Anonymous Narrative"; it was published in the Paesi novamente retrovati, Chaps. 63-83. ${ }^{67}$

- Ludovico de Varthema (c. 1470-1517), an Italian adventurer and keen observer who wrote an account of his travels to Egypt, the Middle East, India and the islands of the Indian Ocean, though there is some dispute about whether in fact he traveled anywhere east of Cairo. ${ }^{68}$ His narrative was published soon after his return to Europe in 1508, first in Italian (1510), then in Latin (1511), and then in an illustrated edition in German (1515). ${ }^{69}$

- Joseph the Indian, or Priest Joseph (fl. 1490-1518), a Christian priest from Cranganore, India, who shipped with Cabral on his return to Portugal so that he could visit Rome and Jerusalem. During the voyage, and also during his stay in Portugal, he supplied detailed information about southwestern India that may have been published in 1505, and was certainly printed in 1507 as the final chapters of the Paesi novamente retrovati. ${ }^{70}$

For Waldseemüller, the majority of these sources were recent: Varthema's book, of which Waldseemüller made heavy use, was printed just a few years before Waldseemüller created the Carta marina. A number of the other sources he cites were published in the Paesi novamente retrovati in 1507, about a decade before he made the Carta marina.

There are a couple of interesting omissions from Waldseemüller's list. The first is the Travels of Sir John Mandeville, ${ }^{71}$ who claimed to have traveled widely in Asia and Africa. The book was written in the fourteenth century and circulated very widely both in manuscript and print, with incunable editions in ten different languages, ${ }^{72}$ including multiple editions published in Strasbourg (near Waldseemüller) with woodcut illustrations. ${ }^{73}$ The second is the narrative of the travels of Arnold von Harff to the Holy Land, Egypt, and the Indian Ocean in 1496-1499. The work was not published until $1860{ }^{74}$ but circulated in

\footnotetext{
${ }^{67}$ An English translation of the "Anonymous Narrative" is in William Brooks Greenlee, The Voyage of Pedro Álvares Cabral to Brazil and India from Contemporary Documents and Narratives (London: The Hakluyt Society, 1938), pp. 53-94. The earliest surviving version of the Anonymous Narrative is in the Trevisan Manuscript in the Library of Congress: Dursteler, "Reverberations of the Voyages of Discovery" (see note 54), p. 53. There is a Portuguese translation of the Anonymous Narrative in T. O. Marcondes de Sousa, "Relação do Pilôto Anônimo," Revista do Instituto Histórico e Geográfico de São Paulo 45 (1945/1950), pp. 82-108; and in Guedes, A viagem de Pedro Alvares Cabral, pp. $205-226$. ${ }^{68}$ For a good discussion of Varthema's travels see Joan-Pau Rubiés, "Ludovico de Varthema: The Curious Traveller at the Time of Vasco da Gama and Columbus," in his Travel and Ethnology in the Renaissance: South India through European eyes, 1250-1625 (Cambridge and New York: Cambridge University Press, 2000), pp. 125-163; for an English translation of Varthema see Lodovico de Varthema, The Travels of Ludovico di Varthema in Egypt, Syria, Arabia Deserta and Arabia Felix, in Persia, India, and Ethiopia, A.D. 1503 to 1508, translated from the original Italian edition of $1510 \ldots$ by John Winter Jones and edited, with notes and an introduction, by George Percy Badger (London: The Hakluyt Society, 1863). Notes on the different editions and translations of the work are on pp. iii-xvi.

${ }^{69}$ The illustrated edition in question is Lodovico de Varthema, Die Ritterlich und lobwirdig rayß des gestrengen und über all ander weyt erfarnen ritters und Lantfarers herren Ludowico vartomans von Bolonia (Augsburg: H. Miller, 1515). On the re-use of the illustrations from this edition by authors other than Waldseemüller see Lisa Voigt and Elio Brancaforte, "The Traveling Illustrations of Sixteenth-Century Travel Narratives," PMLA 129.3 (2014), pp. 365-398.

${ }^{70}$ For discussion of the information Joseph conveyed see Antony Vallavanthara, India in 1500 A.D.: The Narratives of Joseph the Indian (Mannanam: Research Institute for Studies in History, 1984); and Antony Vallavanthara, "The Indian Coasts and the Malabar Society as Brought to the Notice of the Europeans by Joseph the Indian," in K. S. Mathew, Teotónio R. de Souza, Pius Malekandathil, eds., The Portuguese and the Socio-Cultural Changes in India, 1500-1800 (Tellicherry, Kerala: Institute for Research in Social Sciences and Humanities, MESHAR, 2001), pp. 93-119. For an English translation of Joseph's account see William Brooks Greenlee, "The Account of Priest Joseph," in The Voyage of Pedro Álvares Cabral to Brazil and India from Contemporary Documents and Narratives (London: The Hakluyt Society, 1938), pp. 95-113.

${ }^{71}$ John Larner suggests that "John Mandeville" was the pen name of Jan de Langhe in "Plucking Hairs from the Great Cham's Beard: Marco Polo, Jan de Langhe, and Sir John Mandeville," in Suzanne Conklin Akbari and Amilcare Iannucci, eds., Marco Polo and the Encounter of East and West (Toronto: University of Toronto Press, 2008), pp. 133-155.

${ }^{72}$ On the diffusion of Mandeville's work see Iain Higgins, "Imagining Christendom from Jerusalem to Paradise: Asia in Mandeville's Travels," in Scott Westrem, ed., Discovering New Worlds: Essays on Medieval Exploration and Imagination (New York: Garland, 1991), pp. 91-114, esp. 9596. There is a good preliminary list of manuscripts of Mandeville in Josephine Waters Bennett, The Rediscovery of Sir John Mandeville (New York: Modern Language Association of America, 1954), Appendix 1, “The Manuscripts," pp. 265-334.

${ }^{73}$ Johann Prüss in Strasbourg published editions of Mandeville in 1483, 1484, and 1488; Bartholomäus Kistler in 1499; and Johann Knobloch in 1507 - all of these editions illustrated. There were many other non-Strasbourg editions in both Latin and German to which Waldseemüller might have had access.

${ }^{74}$ Arnold von Harff, Die Pilgerfahrt des ritters Arnold von Harff von Cöln durch Italien, Syrien, Aegypten, Arabien, Aethiopien, Nubien, Palästina, die Türkei, Frankreich und Spanien, wie er sie in den jahren 1496 bis 1499 vollendet, beschrieben und durch zeichnungen erläutert hat, ed. Eberhard von Groote (Cologne: J. M. Heberle, 1860). The modern edition in German is Helmut Brall-Tuchel and Folker Reichert, eds., RomJerusalem - Santiago: das Pilgertagebuch des Ritters Arnold von Harff (1496-1498) (Cologne: Böhlau, 2007), and for an English translation see Arnold von Harff, The Pilgrimage of Arnold von Harff, Knight, from Cologne, through Italy, Syria, Egypt, Arabia, Ethiopia, Nubia, Palestine, Turkey, France and Spain, Which He Accomplished in the Years 1496 to 1499, trans. Malcolm Letts (London: Hakluyt Society, 1946). For bibliography on his narrative see Werner Paravicini, ed., Europäische Reiseberichte des späten Mittelalters: eine analytische Bibliographie (Frankfurt am Main and New York: Peter Lang, 1994-), vol. 1, pp. 274-281.
} 
manuscript, a number of which were illustrated. ${ }^{75}$ Given Waldseemüller's wide knowledge of recent travel literature, it is difficult to imagine that he was not familiar with von Harff's book, and in fact it would be at least somewhat ironic, as his 1507 map has data that also appears in von Harff, probably by way of a map by Martellus. ${ }^{76}$ Despite the extravagance of Mandeville's narrative, he was accepted as an authority by some other Renaissance cartographers and geographers, ${ }^{77}$ but it seems likely that Waldseemüller chose not to use Mandeville and von Harff because he considered them unreliable.

If we look at Waldseemüller's list again in the light of his 1507 map, one of the authors included in this list and another who is omitted from it are surprising. The 1507 map proclaims Amerigo Vespucci as the discoverer of the New World: Vespucci's portrait is at the top of the map, and the southern part of the New World bears the name "America," which Waldseemüller and Ringmann created from "Amerigo."78 Moreover, their book Cosmographiae introductio includes Vespucci's accounts of his four voyages. So it is surprising that Waldseemüller does not include Vespucci in his list of sources for the Carta marina, but does include Columbus. ${ }^{79}$ Indeed, the Carta marina makes it clear that Waldseemüller had realized, probably through the account of Columbus's 1492 voyage in the Paesi novamente retrovati, the precedence of Columbus as discoverer: the name "America" does not appear on the map, and a legend in the South Atlantic explicitly names Columbus as the first discoverer of the New World, Cabral as the second, and Vespucci as the third (Legend 10.2).

Thus in making his Carta marina Waldseemüller not only abandoned the Ptolemaic cartographic model in favor of the nautical chart model; he also abandoned Vespucci as principal discoverer of the New World in favor of Columbus. The fact that the two figureheads, Ptolemy and Vespucci, displayed so prominently at the top of the 1507 map, had both fallen by the wayside in 1516 is a powerful testament to the rapid development of Waldseemüller's cartographic thought and his willingness to change his ideas in light of new information, as well as to the dynamism of early sixteenth-century cartography in general. Waldseemüller's willingness to discard all of the work he had invested in the 1507 map is all the more impressive given that the map was evidently well received. ${ }^{80}$ It was not the demands of customers, but rather his own

\footnotetext{
${ }^{75}$ On the manuscripts of von Harff's narrative see Patrick de Never and Volker Honemann, "Zur Überlieferung der Reisebeschreibung Arnolds von Harff," Zeitschrift für deutsches Altertum und deutsche Literatur 107.2 (1978), pp. 165-178; and Peter A. Jorgensen and Barbara M. Ferré, "Die handschriftlichen Verhältnisse der spätmittelalterlichen Pilgerfahrt des Arnold von Harff," Zeitschrift für deutsche Philologie 110.3 (1991), pp. 406-421. The illustrated manuscripts of von Harff which are in more or less public collections are Bonn, Universitätsbibliothek, Cod. S 447; Schloß Burgsteinfurt in Steinfurt (Westf.), Fürstl. Bentheim-Steinfurtische Schloßbibl., Hs. 4; Darmstadt, Landes- und Hochschulbibliothek, Hs. 138; Schloß Erpenburg (bei Büren), Archiv der Freihernn von und zu Brenken, Cod. HX. 100; Gießen, Universitätsbibliothek, Hs. 163, ff. 5r-155r; Cologne, Historisches Archiv der Stadt, Cod. W* 382; Munich, Staatsbibliothek, Cgm 2213/32, ff. 451r-615v; Trier, Stadtbibliothek, Hs. 1938/1469 $8^{\circ}$, and Hs. 2424/2387 $2^{\circ}$; and Wolfenbüttel, Herzog August Bibliothek, Cod. 177 Helmst, ff. 207r-258v.

${ }^{76}$ I discussed the commonalities between Waldseemüller and von Harff in my lecture "Evidence for a Lost Map Used by Waldseemüller in his Depiction of Eastern Africa and the Indian Ocean," delivered May 15, 2009, at the conference "Exploring Waldseemüller's World," May 14 and 15,2009 , at the Library of Congress, Washington, DC. Video of the talk is available at http://www.loc.gov/today/cyberlc/feature_wdesc.php?rec= 4569 (third talk in panel).

${ }^{77}$ See C. W. R. D. Moseley, "Behaim's Globe and 'Mandeville's Travels,"” Imago Mundi, 33.1 (1981), pp. 89-91; and Christiane Deluz, "Le Livre Jehan de Mandeville, autorité géographique à la Renaissance," in Jean Céard and J.-Cl. Margolin, eds., Voyager à la Renaissance: Actes du colloque de Tours 1983 (Paris: Maisonneuve et Larose, 1987), pp. 205-220. Gerard Mercator also cites Mandeville as a source about Java and the southern hemisphere on his world map of 1569, but Mercator ends by saying that Mandeville is "an author unbelievable in other respects"- -see Nicolas Crane, Mercator: The Man Who Mapped the Planet (New York: Henry Holt, 2002), p. 226. Also see "Text and Translation of the Legends of the Original Chart of the World by Gerhard Mercator, Issued in 1569," Hydrographic Review 9.2 (1932), pp. 7-45, at 44-45.

${ }^{78}$ The relevant passage in the Cosmographiae introductio is in Chap. 7, on signature a iii ${ }^{\mathrm{r}}$ in the 1507 edition. In Fischer and von Wieser, The 'Cosmographiae introductio' of Martin Waldseemüller (see note 7), the passage is on p. xxv (Latin) and 63 (English); and in Hessler, The Naming of America (see note 7), it is on p. 94. For bibliography on the naming of America see note 7 above.

${ }^{79}$ Waldseemüller and Ringmann's favoring of Vespucci over Columbus as discoverer of the New World in the Cosmographiae introductio and the 1507 map is to be seen in the context of the greater interest in and popularity of accounts of Vespucci's voyages rather than Columbus's: see Rudolf Hirsch, "Printed Reports on the Early Discoveries and Their Reception," in Fredi Chiappelli, Michael J. B. Allen, and Robert Louis Benson, eds., First Images of America: The Impact of the New World on the Old (Berkeley: University of California Press, 1976), vol. 2, pp. 537-551, esp. 546-547. ${ }^{80}$ Waldseemüller mentions the positive reception of his 1507 map in a dedicatory letter addressed to his colleague Matthias Ringmann in Waldseemüller's Architecturae et perspectivae rudimenta, which was published with Gregor Reisch's Margarita philosophica nova (Strasbourg: Grüninger, 1508). Waldseemüller wrote: Cosmographiam universalem tam solidam quam planam non sine gloria et laude per orbem disseminatam nuper composuimus, depinximus, et impressimus: "We recently composed, drew, and printed a world map and globe which have been disseminated across the world, not without fame and praise.” This letter is quoted by M. d'Avezac, Martin Hylacomylus Waltzemüller (see note 5), pp. 109-110. Johnson, Carta marina (see note 21), p. 125, note 22, also cites part of the passage. Waldseemüller also records René II's enthusiastic reception of his 1507 map in the dedicatory letter in Ringmann's Instructio manuductionem prestans in Cartam itinerariam (Strasbourg: Grüninger, 1511): Neque enim obliti sumus qua aurium clementia: quam hilari vultu et quam grato animo generalem orbis descriptionem: ac alia etiam litterarij laboris nostri monimenta sibi oblata a nobis susceperit, "For we have not forgotten with what indulgent hearing, with what a happy face, and with what a grateful spirit he received our general map of the world, and other samples of our literary works that we presented to him." This passage is quoted and translated into French by M. d'Avezac, Martin Hylacomylus Waltzemüller (see note 5), pp. 136-137; and into English by Toby Lester, The Fourth Part of the World: The Race to the Ends of the Earth, and the Epic Story of the Map that Gave America its Name (New York: Free Press, 2009 ), p. 373.
} 
determination to find the best method for representing the world that led him to undertake the creation of an entirely new world map in the Carta marina.

In addition to recognizing Columbus's primacy as discoverer of the New World, in the Carta marina Waldseemüller adopted a Columbian conception of the New World. This can be seen particularly clearly in the different indications of what is west of the New World on the two maps. One of the most striking and oft-discussed aspects of Waldseemüller's 1507 map is his depiction of an ocean west of the New World before the European discovery of the Pacific by Vasco Nuñez de Balboa in September 1513. He also explicitly stated in the Cosmographiae introductio that the New World was an island. ${ }^{81}$ This depiction and statement have generated claims of an earlier, pre-Balboa discovery of the Pacific by a European voyage of which no other record survives. But there is a much simpler explanation for Waldseemüller's depiction. Marco Polo had said that Japan was 1500 miles east of mainland $\mathrm{Asia}^{82}$; Polo clearly stated that Japan was an island; so there must be water east of Japan, and thus between Japan and the New World. Quite probably on the basis of this reasoning, Waldseemüller shows water separating the New World from Asia on the 1507 map: they are two distinct regions.

Columbus had been seeking a route to Asia by sailing west, and during all four of his voyages and to the end of his life believed that he had been in Asia, albeit in some previously unknown outlying reaches of the continent. ${ }^{83}$ This is the view of the New World that Waldseemüller adopts in the Carta marina. It is particularly clear in the legend on North America, on sheet 1, which reads TERRA DE CVBA - ASIE PARTIS, "The land of Cuba, part of Asia" (Legend 1.1) ${ }^{84}$ Other evidence for this view is in the legend on sheet 5 describing Hispaniola in the Caribbean, which begins Spagnolla que et Offira dicitur, "Hispaniola, which is also called Ophir" (Legend 5.1) —identifying the island with the region mentioned in the Bible from which gold and other riches were brought to King Solomon. ${ }^{85}$ Columbus had shown great interest in the location of Ophir, and had himself asserted that Hispaniola was to be identified with that region. ${ }^{86}$ Thus in the Carta marina Waldseemüller has adopted a Columbian view of the New World. His decisions to show less of the ocean east of Asia than Caverio on his chart, and to exclude Japan, should be seen as part of this same new perspective.

In attempting to update his information about and depiction of the New World in the Carta marina, Waldseemüller inadvertently took a step backwards, since Columbus's belief that the New World was Asia was incorrect. ${ }^{87}$ But in other parts of the map, particularly in Asia and the Indian Ocean, the updating is breathtaking, and in examining the changes one appreciates Waldseemüller's assertion that the 1507 map shows the world according to old authors, while the Carta marina depicts the world according to the very latest information.

On the 1507 map, in western Asia Waldseemüller follows Ptolemy, while in eastern Asia—which was unknown to Ptolemy - he follows Marco Polo. Thus in western Asia his source was more than a thousand years old, while in eastern Asia it was some two hundred years old. On the 1516 Carta marina, Waldseemüller uses information from John of Plano Carpini,

\footnotetext{
${ }^{81}$ In Chap. 9 of the Cosmographiae introductio, Waldseemüller writes of the four parts of the world, "the first three parts [i.e. Europe, Africa and Asia] are continents, and the fourth [America] is an island, since it is seen to be completely surrounded by water."

${ }^{82}$ On the distance of Japan from mainland Asia see note 36 above.

${ }^{83}$ On Columbus's belief that his discoveries were part of Asia see George E. Nunn, "Did Columbus Believe that he Reached Asia on his Fourth Voyage?" in The Geographical Conceptions of Columbus: A Critical Consideration of Four Problems (New York: American Geographical Society, 1924); expanded edition with an essay titled "The Test of Time" by Clinton R. Edwards (Milwaukee: American Geographical Society Collection of the Golda Meir Library, University of Wisconsin-Milwaukee; and New York: American Geographical Society, 1992), pp. 54-90; E. G. R. Taylor, "Idée Fixe: The Mind of Christopher Columbus," The Hispanic American Historical Review 11.3 (1931), pp. 289-301; John H. Parry, "Asia-in-the-West," Terrae Incognitae 8 (1976), pp. 59-72; Folker Reichert, "Columbus und Marco Polo-Asien in Amerika. Zur Literaturgeschichte der Entdeckungen," Zeitschrift für historische Forschung 15 (1988), pp. 1-63, and Chet Van Duzer, "Geography," in John Hessler, Daniel De Simone, and Chet Van Duzer, Christopher Columbus Book of Privileges: 1502, the Claiming of a New World (Delray Beach, FL: Levenger, and Washington, DC: Library of Congress, 2014), pp. 1-26, at 8-11.

${ }^{84}$ For discussion of the background of Waldseemüller's depiction of the "Terra de Cuba," see Donald L. McGuirk Jr., "The Depiction of Cuba on the Ruysch World Map,” Terrae Incognitae 20 (1988), pp. 89-97.

${ }^{85}$ On the riches from Ophir see 1 Kings 9:28, 10:11, and 22:48; and 2 Chronicles 8:18 of the Bible. For discussion of claims that Ophir was located in the New World see James Romm, "Biblical History and the Americas: The Legend of Solomon's Ophir, 1492-1591," in Paolo Bernardini and Norman Fiering, eds., The Jews and the Expansion of Europe to the West, 1450 to 1800 (New York: Berghahn Books, 2001), pp. 27-46; Gerald Arthur Ward, "Columbus, Jerusalem, and Ophir: A Voyage to the Ends of Earth and Time," in his "Restoring the Shattered World: The Apocalyptic Mercantilism of Samuel Purchas and the Revelation of World Trade,” Ph.D. Dissertation, Boston University, 2003, pp. 227-248; and Jorge Magasich-Airola and Jean-Marc de Beer, "King Solomon's Mines in America," in America Magica: When Renaissance Europe Thought it Had Conquered Paradise, trans. Monica Sandor (London and New York: Anthem Press, 2007), pp. 53-67.

${ }^{86}$ Columbus asserts that Hispaniola is to be identified with Ophir in his account of his Third Voyage. See Christopher Columbus, The Four Voyages of Columbus: A History in Eight Documents, ed. and trans. Cecil Jane (New York: Dover Publications, 1988), vol. 2, p. 6.

${ }^{87}$ On the development of ideas about the New World see David Beers Quinn, "New Geographical Horizons: Literature," in Fredi Chiappelli, Michael J. B. Allen, and Robert Louis Benson, eds., First Images of America: The Impact of the New World on the Old (Berkeley: University of California Press, 1976), vol. 2, pp. 635-658.
} 
Simon of Saint Quentin, and an unidentified source to describe Russia (the upper left part of sheet 3), using medieval names of Grand Duke's domain (Russia) and the Principality of Moscow (Moscovia Regalis); the inhabitants are said to follow the "Greek Rite," meaning that they belong to the Orthodox Church (see Legends 3.2 and 3.3). The contrast with the 1507 map is stark: there the information comes from Ptolemy, who wrote long before the East-West Schism of 1054 and the founding of Moscow in 1147. In addition to much of the information being more recent on the 1516 map, it is far more detailed, with particulars about the religion and political relationships of the inhabitants and sovereigns.

In the Middle East on the 1507 map, Persia is merely a collection of place names from Ptolemy, while on the Carta marina, in addition to there being modern names for the cities, there is a legend describing the region that mixes information from Marco Polo and a recent account from Varthema (see Legend 3.35):

persia prouincia nobilis destructa multum per tartaros sed nunc sub ditione victoriosssimi [sic] regis Sophi reparata est enim diuisa in octo regna sunt Macometani et homines fallaces

The noble country of Persia was largely destroyed by the Tartars, but now, under the control of the unstoppable king Sophi, it has been restored and divided into eight realms. The people are followers of Mohammed and are deceitful.

"Sophi" is Shah Isma'il es-Sufi (1487-1524), the founder of the Safavid dynasty, who gained control over Persia and Khorasan (now Iran and adjoining territories to the east) around the year $1500{ }^{88}$ This information was very recent indeed, compared with that on the 1507 map, and much more detailed, as it does not merely list place names, but also reveals the current political situation.

Northern India (the lower left hand part of sheet 4) is another area where Waldseemüller was following the most recent sources, but since those sources recycled traditional information, his depiction of the area is not, in fact, particularly modern. Both John of Plano Carpini and Pierre d'Ailly describe monstrous races of men in India-men with the heads of dogs, Cyclopes, men whose faces are in their chests (elsewhere called blemmyae), pygmies, and so on. In listing these races, Plano Carpini and d'Ailly are availing themselves of the traditional view of India as a land of marvels and monsters, a perception that goes back to ancient Greece. ${ }^{89}$ Waldseemüller is the first cartographer to depict several of the monstrous races of India together on a map, but the source material, although it appears in relatively recent books, is old. ${ }^{90}$

In the northeastern corner of the map (sheet 4) is a large image of the Great Khan in his tent, and to the left of him, a long legend describing Tartaria (northern and central Asia, from the Caspian Sea to the Pacific) - the terrain, the customs, and the Khan's great power (Legend 4.16). Marco Polo gives detailed descriptions of the Khan and his realm, and Waldseemüller made heavy use of Polo in his 1507 map, but curiously, he says almost nothing about the Khan either on that map or in the Cosmographiae introductio. ${ }^{91} \mathrm{He}$ indicates some lands under the Khan's control with little escutcheons, or shield-shaped

\footnotetext{
${ }^{88}$ For bibliography on Sophi see Legend 3.35. Sophi is also illustrated in some of the manuscript maps by Battista Agnese, for example on his atlas of nautical charts in New Haven, at Yale's Beinecke Rare Book and Manuscript Library, MS 560, map 3, an image of which is available via the Beinecke's Digital Library. Sophi also appears on the unsigned chart Munich, Bayerische Staatsbibliothek, Cod. Icon. 131, which is discussed (but misdated to c. 1505) and well-illustrated in Ivan Kupčík, Münchner Portolankarten: Kunstmann I-XIII und zehn weitere Portolankarten = Munich Portolan Charts: Kunstmann I-XIII and Ten Other Portolan Charts (Munich: Deutscher Kunstverlag, 2000), pp. 115-119; and on an undated and previously unattributed chart in the Nordenskiöld Collection in Helsinki University Library, illustrated in black and white in A. E. Nordenskiöld, Periplus: An Essay on the Early History of Charts and Sailing-Directions, trans. Francis A. Bather (Stockholm: P. A. Norstedt \& Söner, 1897; New York: B. Franklin, 1967), plate 23. Sophi is also mentioned on the unsigned chart attributable to Agnese which is Budapest, National Széchényi Library, Manuscript Collection, Cod. Lat. 353. And this sovereign also appears in a nautical atlas by Aloisio Cesani, Parma, Biblioteca Palatina, MS Parm. 1616, from 1574. This atlas is briefly discussed and some maps from it are reproduced in Carte pernavigare: la raccolta di portolani della Biblioteca Palatina di Parma (Parma: MUP, Monte Università Parma, 2009), pp. 80-97; the map with Sophi is reproduced on pp. 86-87, and there is a detail of him on p. 88.

${ }^{89}$ For discussion of India as a locus of marvels and monsters see Rudolf Wittkower, "Marvels of the East: A Study in the History of Monsters," Journal of the Warburg and Courtauld Institutes 5 (1942), pp. 159-197, reprinted in his Allegory and Migration of Symbols (Boulder, CO: Westview Press, 1977), pp. 45-74; James Romm, "Belief and Other Worlds: Ktesias and the Founding of the 'Indian Wonders'," in George E. Slusser and Eric S. Rabkin, eds., Mindscapes: The Geography of Imagined Worlds (Carbondale: Southern Illinois University Press, 1989), pp. 121-135, esp. 121-122; Andrea Rossi-Reder, "Wonders of the Beast: India in Classical and Medieval Literature," in Timothy S. Jones and David A. Sprunger, eds., Marvels, Monsters, and Miracles: Studies in the Medieval and Early Modern Imaginations (Kalamazoo: Medieval Institute Publications, 2002), pp. 53-66; and Chet Van Duzer, "Hic sunt dracones: The Geography and Cartography of Monsters," in Asa Mittman and Peter Dendle, eds., The Ashgate Research Companion to Monsters and the Monstrous (Farnham, England, and Burlington, VT: Ashgate Variorum, 2012), pp. 387-435, esp. 402-409.

${ }^{90}$ For discussion of the monstrous races in India on the Carta marina see Chet Van Duzer, "A Northern Refuge of the Monstrous Races: Asia on Waldseemüller's 1516 Carta marina," Imago Mundi 62.2 (2010), pp. 221-231.

${ }^{91}$ The apparent lack of interest in the Great Khan on the 1507 map is in line with earlier humanist geography: for example, the Mongols are absent from Aeneas Silvius Piccolomini's Asia, which was completed around 1461: see Margaret Meserve, "From Samarkand to Scythia: Reinventions of Asia in Renaissance Geography and Political Thought," in Zweder von Martels and Arjo Vanderjagt, eds., Pius II 'el più expeditivo pontifice': Selected Studies on Aeneas Silvius Piccolomini (1405-1464) (Leiden and Boston: Brill, 2003), pp. 13-39.
} 
emblems, bearing the Khan's symbol (the anchor) in western Asia, but strangely, not in eastern Asia. The great emphasis on the Khan on the Carta marina should be read as part of Waldseemüller's new emphasis on practical matters: the Khan represented a threat to Europe, so Waldseemüller provides information about him, and a large image to emphasize his importance. As for the legend describing Tartaria, this is a case where Waldseemüller used an older source rather than a newer one, for his information comes primarily from John of Plano Carpini, who traveled to Asia a couple of decades before Marco Polo. This is no doubt an indication that Waldseemüller thought Plano Carpini more reliable than Polo.

The Indian Ocean is one of the regions where Waldseemüller's updating of his image of the world is the most dramatic. On the 1507 map, his information about the Indian Ocean comes from Ptolemy and Marco Polo, and his legends about sea monsters come from an illustrated encyclopedia titled Hortus sanitatis, first published in $1491,{ }^{92}$ by way of a large world map by Henricus Martellus. ${ }^{93}$ There are only small bits of information from the recent Portuguese explorations in the Indian Ocean, which followed Vasco da Gama's first voyage from Portugal to India and back in 1497-99: for instance, there is a brief legend about the important trading center of Calicut, which da Gama had reached. ${ }^{94}$

On his Carta marina, almost everything about the Indian Ocean has changed. On the 1507 map, the depiction of Taprobana (modern Sri Lanka) is straight out of Ptolemy. On the 1516 map, in a legend in the upper left corner of sheet 12, Waldseemüller disputes the equatorial position that Ptolemy assigned to the island, siding instead with the Roman author Solinus and evidence from recent Portuguese voyages that place it further south (Legend 12.1); and on sheet 8, he discusses whether Taprobana is to be identified with Sumatra (Legend 8.10). Ptolemy had said there were 1,378 islands near Taprobana, and Waldseemüller quotes him to that effect on the 1507 map; on the 1516 map he instead quotes Varthema's statement - around 1300 years more recent — that there were 8,000 islands near Sumatra (Legend 12.2). Ptolemy's various islands of cannibals, together with the magnetic islands that pull the nails from ships, are simply gone, though there are still cannibals in the area, now on the island of Java, and the information about them now comes from Varthema (Legend 12.3). Here again, Waldseemüller has set aside the information about Java on his 1507 map that came from Marco Polo.

On the 1507 map a short legend describes the trading center of Calicut, ${ }^{95}$ while on the 1516 map, at the right-hand edge of sheet 7 (just west of Calicut, which is at the left-hand edge of sheet 8), a long legend describes the merchandise available in that city (Legend 7.18). It also gives an account of the king and his many wives as well as the unusual sexual and religious practices in the region, and includes a few words about what the people drink and eat (rice, fruit, butter, sugar, and some fish, but no meat) —all of this from Varthema. Then in the lower right-hand corner of the map, a long legend (Legend 12.11) describes the systems of weights and money at Calicut, the regions from which the various spices were brought to that city, and the price of each of them in the Calicut markets, ${ }^{96}$ all of which information comes from Chaps. 82-83 of the 1507 Paesi novamente retrovati. ${ }^{97}$ Again, Waldseemüller is providing an abundance of current practical information about trade, navigation, and local customs.

\footnotetext{
${ }^{92}$ The Hortus sanitatis "major," which is the work that interests us here, is to be distinguished from the Hortus sanitatis "minor," which is a Latin translation of the German herbal often titled Gart der Gesundheit, first published by P. Schoeffer, Mainz, 1485. The herbal published in 1485 has 435 Chapters, while the Hortus sanitatis "major" of 1491 has 1,066 chapters. Details and discussion of the early editions of the Hortus sanitatis are provided by Arnold C. Klebs, "Herbals of 15th Century," Papers of the Bibliographical Society of America 11 (1917), pp. 75-92; and 12 (1918), pp. 41-57, esp. 48-51 and 54-57. A more detailed discussion is in Joseph Frank Payne, "On the "Herbarius' and 'Hortus sanitatis'," Transactions of the Bibliographical Society 6.1 (1901), pp. 63-126, esp. 105-24. The first edition of the work was published in Mainz by Jacob Meydenbach, 23 June 1491. ${ }^{93}$ See Chet Van Duzer, Sea Monsters on Medieval and Renaissance Maps (London: British Library, 2013), pp. 71-76.

${ }^{94}$ The legend about Calicut on Waldseemüller's 1507 map derives from that on Caverio's chart. Translated into English, it says: “The noble province of Calicut: in it there are many minerals, pepper, and other goods of trade that come from many regions: canella (cinnamon), ginger, cloves, sandalwood, and all types of spices. It was found by the King of Portugal." For good accounts of Calicut see Richard M. Eaton, "Multiple Lenses: Differing Perspectives of Fifteenth-Century Calicut," in Laurie J. Sears, ed., Autonomous Histories, Particular Truths: Essays in Honor of John R. W. Smail (Madison, WI: University of Wisconsin, Center for Southeast Asian Studies, 1993), pp. 71-86; reprinted in Eaton's Essays on Islam and Indian History (New Delhi: Oxford University Press, 2001), pp. 76-93; and Geneviève Bouchon, "Un microcosme: Calicut au 16e siècle," in Jean Aubin and Denys Lombard, eds., Marchands et hommes d'affaires asiatiques dans l'Océan Indien et la Mer de Chine 13e-20e siècles (Paris: Editions de l'École des Hautes Études en Sciences Sociales, 1988), pp. 50-57; translated as “A Microcosm: Calicut in the Sixteenth Century," in Denys Lombard and Jean Aubin, eds., Asian Merchants and Businessmen in the Indian Ocean and the China Sea (New Delhi and New York: Oxford University Press, 2000), pp. 40-49.

${ }^{95}$ For a translation of the legend about Calicut on the 1507 map see note 94 above.

${ }^{96}$ It seems likely that Waldseemüller's long legend about the spice trade on the Carta marina was inspired by a long legend on the spice trade on Martin Behaim's globe of 1492. For a transcription of Behaim's legend on the spice trade see E. G. Ravenstein, Martin Behaim, His Life and His Globe (London: G. Philip \& Son, Ltd., 1908), pp. 89-90. Behaim describes the alleged stops that cargoes of spices make on their journey from islands near Java Major, to Java Major itself, to Ceylon, and so on to Europe. Behaim seems to ascribe considerably too many stages to the journey, and the subject of his legend (the route the spices take) is different from Waldseemüller's (the sources and prices of the spices), but nonetheless Behaim's legend probably prompted Waldseemüller to think about a more detailed and informative legend about spices, with updated information.

${ }^{97}$ The Chapters of the Paesi on the systems of weights and money used in Calicut and the sources and prices of the spices are translated into English in Greenlee, The Voyage of Pedro Álvares Cabral (see note 70), pp. 91-94.
} 
Waldseemüller updated his portrayal of the Indian Ocean in other ways, among them his treatment of the sea monsters. On his 1507 map, several legends describe sea monsters in the Indian Ocean, such as this one just north of Madagascar:

Hic cernitur orcha mirabile monstrum mari[n]um ad modum [s]olis cum reverberat cuius figura vix describi potest nisi quod est pelle mollis et carne in mensa.

Here is seen the orca, an extraordinary sea monster, like the sun when it glitters, whose form can hardly be described, except that its skin is soft and its body huge.

Although this information ultimately comes from the illustrated encyclopedia Hortus sanitatis, Waldseemüller's source for his legends about Indian Ocean sea monsters on the 1507 map was Henricus Martellus's large world map discussed earlier. ${ }^{98}$ On the 1516 map, these sea monsters are gone, and the cartographer presents just one image of a sea monster in the southern ocean (sheet 11), south of the southern tip of Africa. In this image King Manuel of Portugal rides a sea monster through the waves, holding aloft a scepter and the banner of Portugal, proclaiming his nation's mastery of the ocean, particularly of the passage to India around the Cape of Good Hope. The image alludes to a new title that Manuel had adopted following Vasco da Gama's return from his first voyage to India, Senhor da conquista e da navegação e comércio de Etiópia, Arábia, Pérsia e da Índia, "Lord of the conquest, and navigation, and commerce of Ethiopia, Arabia, Persia and India" - the adoption of which title is reported in the Paesi novamente retrovati, Chap. $62 .{ }^{99}$

The differences between the sea monsters on the two maps reflect a radical reconceptualization of the Indian Ocean. Most of the sea monsters on the 1507 map - all of which derive from Martellus - are dangerous, and thus would discourage navigation, while the image of King Manuel riding a sea monster on the Carta marina boldly proclaims human control over the dangers of the sea, and by extension, dominion over the oceans themselves. ${ }^{100}$ The riches on the distant shores of the Indian Ocean are no longer mere abstractions, things told of in tales; they are now commodities that are weighed out and sold in markets at specific prices (which are listed in the lower right corner of the map). And those markets can be reached by ship along well-established routes ${ }^{101}$ that are evidently untroubled by sea monsters. In the short space of nine years, Waldseemüller had set aside an essentially medieval view of the ocean and adopted a much more modern conception.

\subsection{The Carta Marina's Iconographical Program, and Its Sources}

As mentioned earlier, in creating the Carta marina, Waldseemüller used Caverio's chart as a basis, but added so many features as to create something essentially new: it has much more geographical detail in the hinterlands, far more textual information, and a more elaborate artistic decoration. This increased level of decoration sets the map apart not only from Caverio's chart but also from the 1507 map. The borders of the 1507 map are decorated with finely depicted wind-heads and the portraits of Ptolemy and Vespucci, but the map proper is artistically quite plain: there are renderings of mountains and small trees, flags and some small coats of arms, one city in Asia, one elephant and a few people in Africa, one ship in the South Atlantic and one parrot in South America, but little more. The Carta marina, on the other hand, boasts a rich and ambitious iconographical program, particularly in Asia.

\footnotetext{
${ }^{98}$ This legend about the orca comes from the Hortus sanitatis, "De piscibus," Chap. 64. I discuss the dependence of the sea monster legends on Waldseemüller's 1507 map on those on the Yale Martellus map in Chet Van Duzer, Henricus Martellus's World Map at Yale (c. 1491): Multispectral Imaging, Sources, Influence (New York: Springer, 2018), pp. 64-66. Also see my Sea Monsters on Medieval and Renaissance Maps (London: British Library, 2013), pp. 71-76.

${ }^{99}$ The passage about Manuel's title appears in the so-called Second Letter of Girolamo Sernigi, and is translated into English in Ravenstein, $A$ Journal of the First Voyage (see note 57), pp. 137-141, at p. 141. Manuel's title also appears in another document that Waldseemüller had (see Legend 12.5), namely the Epistola potentissimi ac inuictissimi Emanuelis Regis Portugaliae \& Algarbiorum \&c. De victoriis habitis in India \& Malacha: ad S. in Christo Patrem \& D[omi $] n[u] m$ nostrum D[omi $] n[u] m$ Leonem X. Pont. Maximum (Rome: Impressa per Iacobum Mazochium, 1513). For an excellent discussion of Manuel's title see Luís Filipe F. R. Thomaz, "L'idée imperiale manueline," in Jean Aubin, ed., La découverte, le Portugal et l'Europe: actes du colloque, Paris, les 26, 27 et 28 mai 1988 (Paris: Fondation Calouste Gulbenkian, Centre Culturel Portugais, 1990), pp. 35-103, at 41-47; also see Paulo Pereira, “'Armes divines': la propagande royale, l'architecture manuéline et l'iconologie du pouvoir," Revue de l'Art 133 (2001), pp. 47-56, esp. 49.

${ }^{100}$ See Chet Van Duzer, Sea Monsters on Medieval and Renaissance Maps (London: British Library, 2013), pp. 75-76; and "Sea Monsters on Maps-The Transition from the Middle Ages to the Renaissance," BIMCC Newsletter 46 (May, 2013), pp. 18-19.

${ }^{101}$ For discussion of the commercial opportunities offered by the new discoveries see Christine R. Johnson, The German Discovery of the World: Renaissance Encounters with the Strange and Marvelous (Charlottesville and London: University of Virginia Press, 2008), esp. pp. 88-122. On changing conceptions of the ocean during this period see Hildegard Binder Johnson, "New Geographical Horizons: Concepts," in Fredi Chiappelli, ed., First Images of America: The Impact of the New World on the Old (Berkeley: University of California Press, 1976), vol. 2, pp. 615-633.
} 
On traditional manuscript nautical charts, many of the decorative elements were optional: the person commissioning the chart could choose to have various elements added to a basic chart, including images of cities, animals, trees, ships, and sovereigns (Fig. 1.5). On sumptuous nautical charts made in the fourteenth century, the sovereigns depicted are in North Africa, but on later charts, sovereigns in Asia and sometimes Europe appear as well. The Caverio chart has just one image of a sovereign, the Magnus Tartarus, or Great Khan. Waldseemüller included many images of sovereigns on the Carta marina - a far larger number than on any surviving manuscript nautical chart. The abundance of sovereigns can be interpreted as reflecting Waldseemüller's interest in the world's politics - that is, in adding practical information to the Carta marina. Moreover, Waldseemüller made use of a simple graphical convention that, although common in other media in ancient, medieval and Renaissance art, had essentially not been employed in the depictions of sovereigns on nautical charts ${ }^{102}$ : he used size to indicate the relative importance of the different sovereigns. Waldseemüller's decision to make many of the sovereigns quite small allowed him to include the large number that appear on the map, and also meant that most of the sovereigns are artistically rather simple, and thus took less time to design and to cut into the woodblocks.

Two particularly large images of sovereigns appear on the map, one of the Great Khan in the northeast corner of sheet 4, and the other of King Manuel of Portugal riding the sea monster on sheet 11. It seems likely that Waldseemüller intended the viewer to compare and contrast the greatest power in the East with the greatest power in the West, one powerful on land, the other on the oceans. On Caverio's map, the Great Khan is pudgy and unimposing, while on the Carta marina he is large, stern, and warlike (Fig. 1.6). The image is finely executed, and was probably made by a special artist rather than by Waldseemüller himself (we have no evidence that Waldseemüller had any woodcutting skills). ${ }^{103}$ This likelihood is increased by the fact that some details of the image do not agree as well with Waldseemüller's textual sources as we might expect. The Khan's facial features do not agree with Plano Carpini's description of typical Tartar features, for example, and while the Khan's braided hair accords with Plano Carpini's description, he also is quite clear that most Tartars do not have beards, but on the Carta marina the Khan does have one. ${ }^{104}$

While the model of Waldseemüller's image of the Khan is unknown, in the case of the image of King Manuel riding the sea monster (Fig. 1.7), which also seems to be the work of a specialized artist, we can identify the likely iconographical sources, as there are few surviving earlier Renaissance images of humans riding sea monsters. The Italian painter Andrea Mantegna produced a print in about 1485-88 known as the Battle of the Sea Gods, in which one of the gods rides a sea monster much as King Manuel does on the Carta marina (Fig. 1.8). ${ }^{105}$ But Waldseemüller's direct source was more likely Jacopo de' Barbari's monumental six-sheet view of Venice of c. 1500, which was itself no doubt influenced by Mantegna: in front of the city, right in front of St. Mark's Square, de' Barbari has an image of Neptune riding a sea monster and holding aloft on his trident a sign that reads AEQVORA TVENS PORTV RESIDEO HIC NEPTVNVS ("I, Neptune, reside here, watching over the seas at this port") (Fig. 1.9). ${ }^{106}$ This is a powerful image of the protection that Venice enjoyed from the

\footnotetext{
${ }^{102}$ The only earlier chart I am aware of where greater size is used to indicate the greater importance of a sovereign is on the Catalan Atlas of 1375: Antichrist in the northeastern corner of the map is much larger than the other sovereigns. There are sovereigns of different sizes on the first map in an atlas of nautical charts by Vesconte Maggiolo (Parma, Biblioteca Palatina, MS parm. 1614), but it is not clear that these differences in size always reflect differences in importance: for illustrations see Carte per navigare: la raccolta di portolani della Biblioteca Palatina di Parma (Parma: MUP, Monte Università Parma, 2009), 56-57 and 64. But Waldseemüller did not have to look far afield for the idea of using size to indicate importance, for this convention was commonly used in depictions of cities on nautical charts.

${ }^{103}$ The sophistication of the Carta marina's image of the Great Khan can be appreciated by comparing it with earlier images of that sovereign, in addition to that on the Caverio map. For example, Paris, Bibliothèque nationale de France, MS 2810, f. $2 \mathrm{v}$, in a famous fifteenth-century manuscript that includes Marco Polo's travels, which shows the Polos paying homage to the Khan, and may be viewed via www.mandragore.bnf.fr ; and Madrid, Biblioteca Nacional, MS 9267, f. 70r, in a manuscript of Louis de Langle's Tractatus de figura seu imagine mundi made c. 1460; the image is reproduced in Marc-Édouard Gautier, ed., Splendeur de l'enluminure: le roi René et les livres (Angers: Ville d'Angers, and Arles: Actes Sud, 2009), p. 235.

${ }^{104}$ For Plano Carpini's description of the Tartars' physical features see Giovanni da Pian di Carpine, Storia dei Mongoli, ed. Enrico Menestò and trans. Maria Cristiana Lungarotti (Spoleto: Centro italiano di studi sull'alto Medioevo, 1989), pp. 232-233 (Latin) and 340 (Italian); and Christopher Dawson, ed., The Mongol Mission: Narratives and Letters of the Franciscan Missionaries in Mongolia and China in the Thirteenth and Fourteenth Centuries (New York: Sheed and Ward, 1955), pp. 6-7.

${ }^{105}$ For discussion of Mantegna's image see Michael A. Jacobsen, "The Meaning of Mantegna's Battle of Sea Monsters," The Art Bulletin 64.4 (1982), pp. 623-629.

${ }^{106}$ On de' Barbari's image of the city see Juergen Schulz, "Jacopo de' Barbari's View of Venice: Map Making, City Views, and Moralized Geography before the Year 1500," The Art Bulletin 60.3 (1978), pp. 425-474, esp. 468 on Neptune; and Deborah Howard, "Venice as a Dolphin: Further Investigations into Jacopo de' Barbari's View," Artibus et Historiae 18.35 (1997), pp. 101-111, esp. 106 (from which I borrow the translation of Neptune's sign).
} 


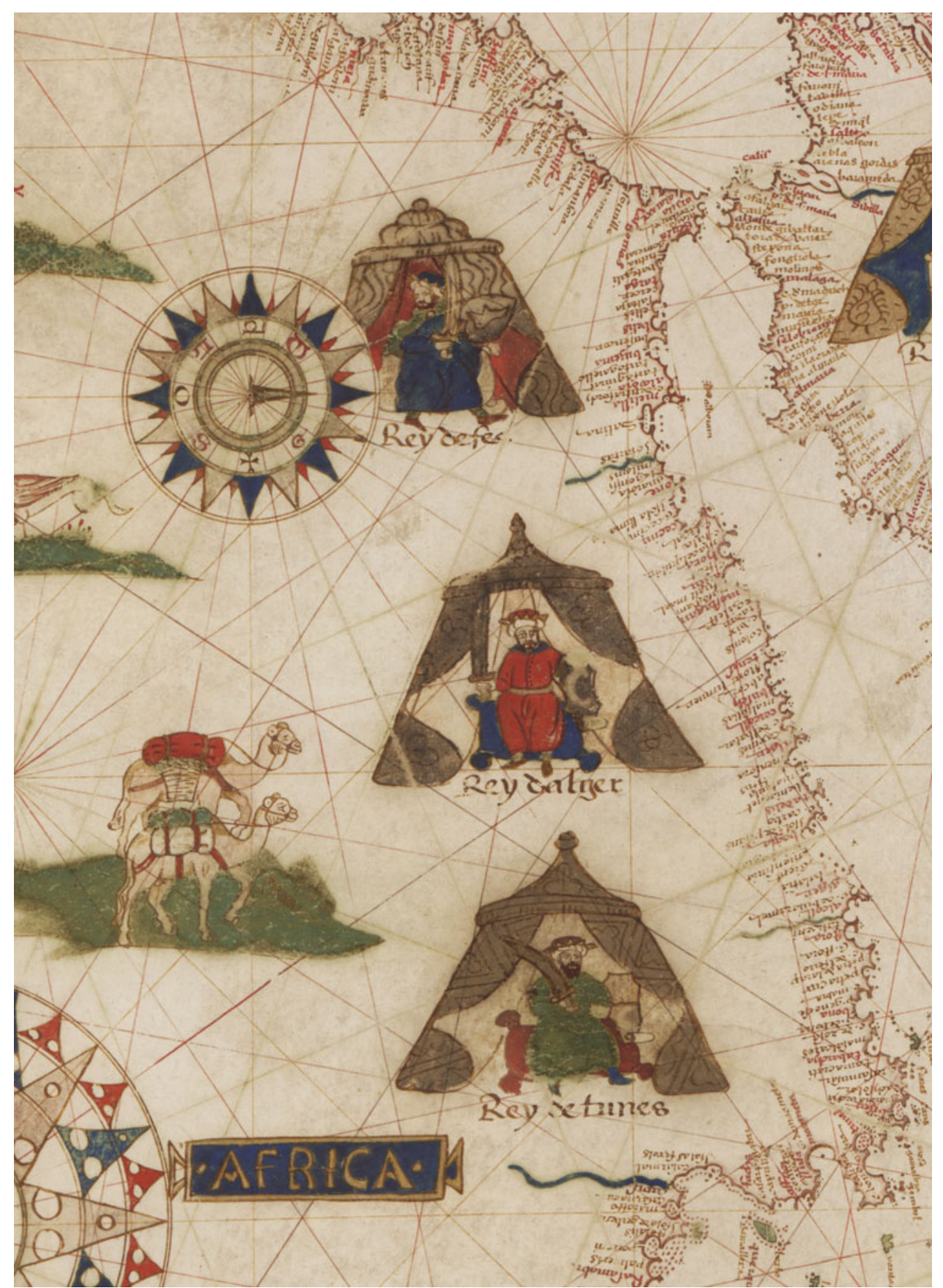

Fig. 1.5 Detail of an elabrately decorated nautical chart made by Matteo Prunes in 1559. Library of Congress, Geography and Map Division, G5672.M4P5 1559 .P7 Vault: Vellum 7. Courtesy of the Library of Congress 


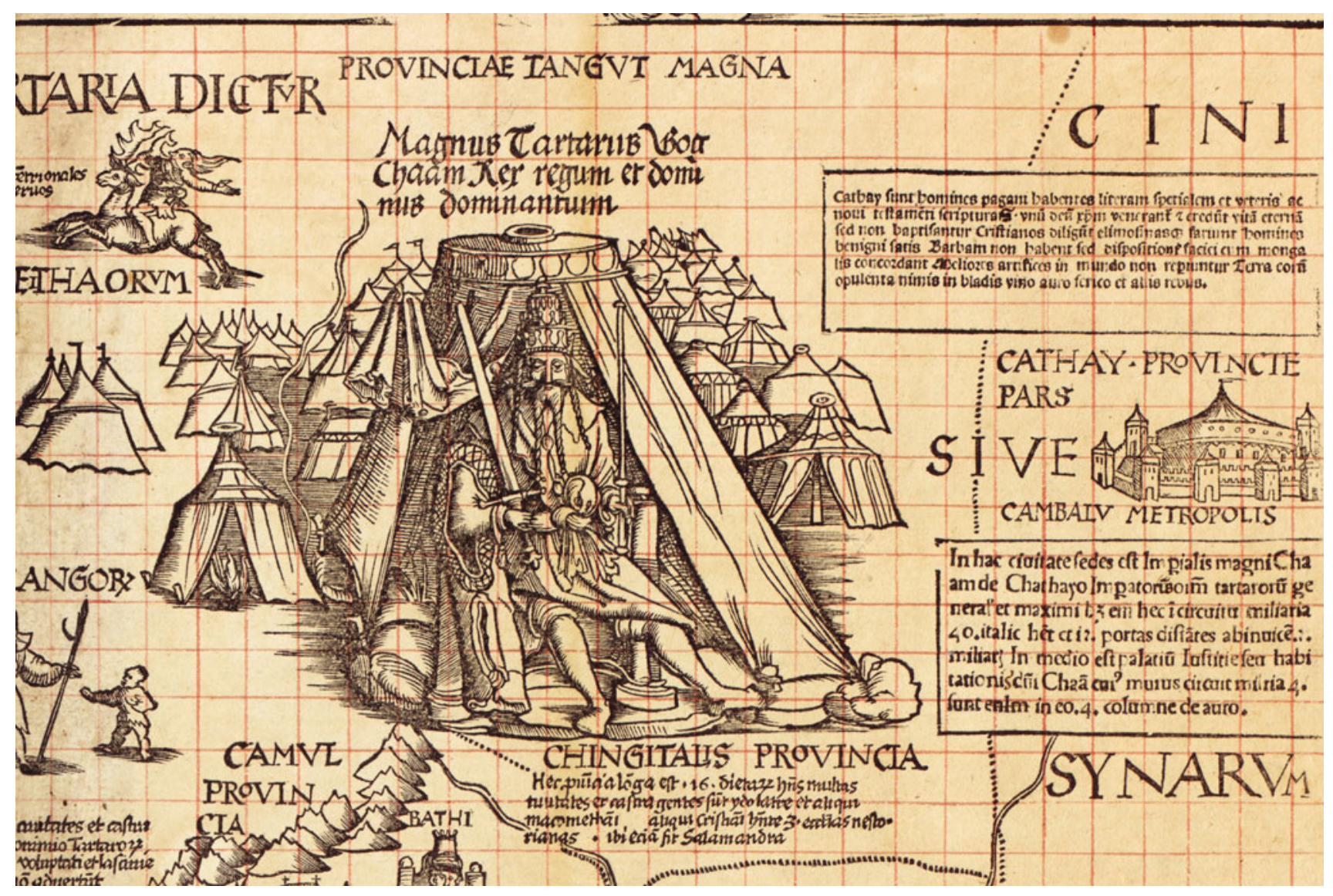

Fig. 1.6 Detail of the Great Khan on Waldseemüller's Carta marina (sheet 4). Courtesy of the Library of Congress

god of the sea, but Waldseemüller's recasting of this image is still more powerful: he has replaced the classical god Neptune with a contemporary king, thus almost effecting an apotheosis of Manuel ${ }^{107}$; and rather than indicating the protection passively enjoyed by Venice, the new image illustrates Portugal's active control of the lanes of navigation to India. ${ }^{108}$

Waldseemüller also made use of recent sources for other images on his map, as part of his effort to create an entirely fresh and modern image of the world. In South America Waldseemüller has an image of an opossum (sheet 5), and this is the earliest surviving European depiction of that animal. Vicente Yáñez Pinzón was the first European to see an opossum in 1499; in fact it was the first marsupial that Europeans had ever seen, and was regarded as a marvel. Pinzón brought an opossum back to Spain and left this description of the creature ${ }^{109}$ :

Between these Trees he saw a strange Monster, the foremost part resembling a Fox, the hinder a Monkey, the feet were like a Mans, with Ears like an Owl; under whose Belly hung a great Bag, in which it carry'd the Young, which they drop not, nor forsake till they can feed themselves.

\footnotetext{
${ }^{107}$ Waldseemüller had included an image of Neptune riding a sea monster on his 1511 Carta itineraria Europae, of which only one exemplar of the 1520 printing survives, in Innsbruck, in the Tiroler Landesmuseum Ferdinandeum. For bibliography on the map see note 14.

${ }^{108}$ On Manuel's status as King of the Ocean see Luís Filipe F. R. Thomaz, "L'idée imperiale manueline," in Jean Aubin, ed., La découverte, le Portugal et l'Europe: actes du colloque, Paris, les 26, 27 et 28 mai 1988 (Paris: Fondation Calouste Gulbenkian, Centre Culturel Portugais, 1990), pp. 35-103, esp. 37 and 41-47. On the politicization of the ocean reflected in the image on Waldseemüller's Carta marina see Elizabeth Mancke, "Early Modern Expansion and the Politicization of Ocean Space," Geographical Review 89.2 (1999), pp. 225-236; and for a brief discussion of the image of Manuel on the sea monster see Gaetano Ferro, Luisa Faldini, Marica Milanesi, and Gianni Eugenio Viola, Columbian Iconography, trans. Luciano F. Farina and Carla Onorato Wysokinski (Rome: Istituto poligrafico e Zecca dello Stato, Libreria dello Stato, 1996), pp. 450-451.

${ }^{109}$ See Charles R. Eastman, "Early Portrayals of the Opossum," The American Naturalist 49.586 (1915), pp. 585-594; and Susan Scott Parrish, "The Female Opossum and the Nature of the New World," The William and Mary Quarterly 54.3 (1997), pp. 475-514, esp. 485. The translation quoted here is from John Ogilby's America (1671), as cited by Parrish.
} 
Fig. 1.7 Detail of King Manuel of Portugal riding a sea monster on Waldseemüller's Carta marina (sheet 11). Courtesy of the Library of Congress

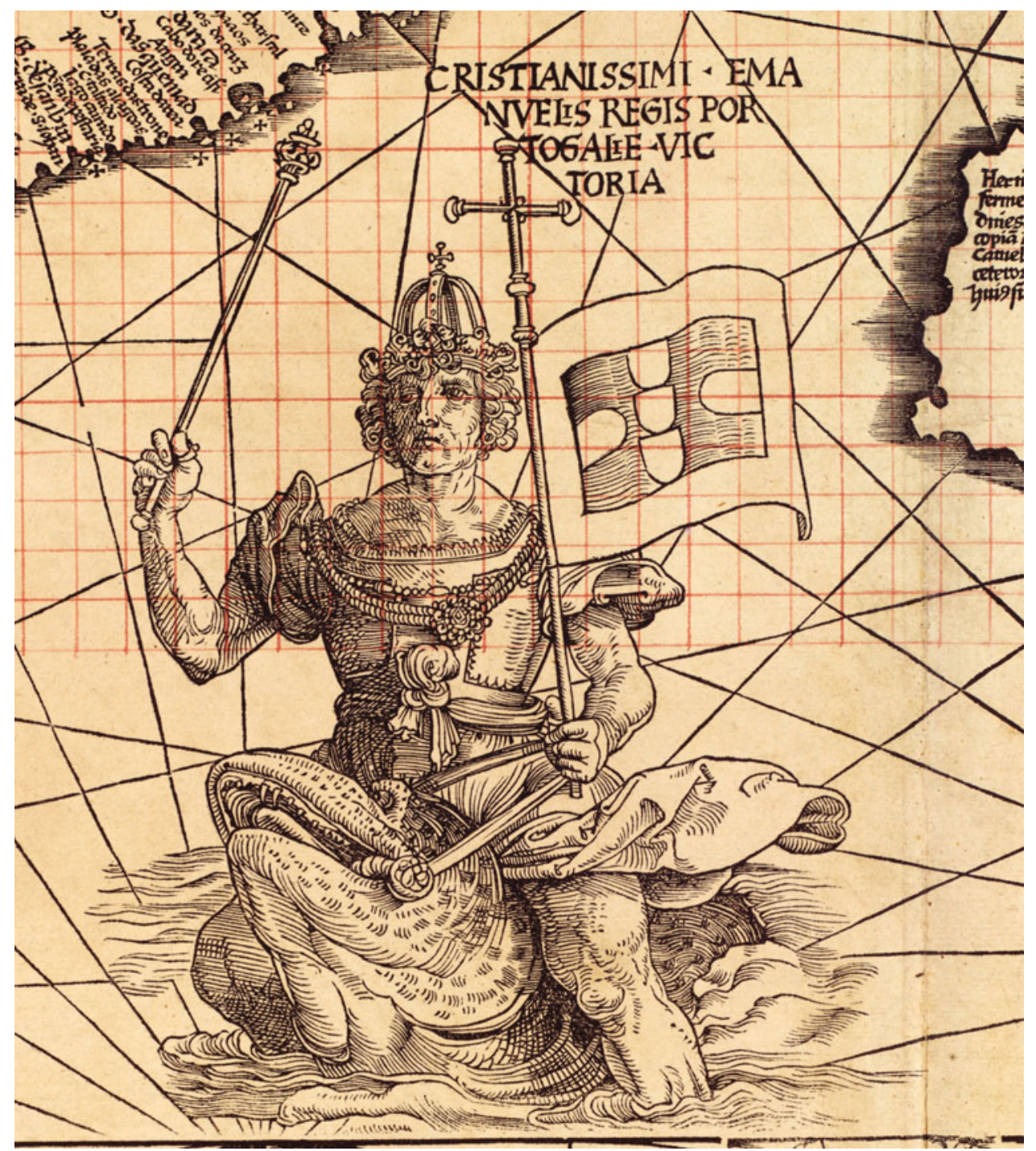

As Waldseemüller's image is quite detailed, it seems likely that it was taken from a contemporary illustration of Pinzón's opossum that no longer survives. ${ }^{110}$ Waldseemüller's image was copied both on later maps and in other media, mostly by way of the reproduction of Waldseemüller's image in Lorenz Fries's Carta marina of 1525, 1530, and $1531{ }^{111}$

In Scandinavia, near the northern edge of the map (sheet 2), the animal that looks like an elephant is intended to be a walrus (Fig. 1.10). The accompanying legend reads (see on Legend 2.3):

Morsus animal ingens quantitate Elephantis huius dentes longos duos et quadrangulares carens quibus iuncturis in pedibus. Reperitur in promontoriis septentrionalibus Norbegie incedit gregatim agmine ducentorum animalium. The

\footnotetext{
${ }^{110}$ Waldseemüller's legend about and image of the opossum are discussed in Gaetano Ferro et al., Columbian Iconography (see note 108), pp. 546-547. Waldseemüller could have read about the opossum in the Libretto de tutta la navigatione, Chap. 31 see Thacher, Christopher Columbus (see note 64), vol. 2, pp. 483 (Italian) and 511-512 (English); and in the Paesi, Chap. 113.

${ }^{111}$ On Fries's Carta marina there is a baby opossum suckling from its mother, and this is clearly the image that Sebastian Münster copied in his Cosmographiae uniuersalis Lib ri] VI (Basel: apud Henrichum Petri, 1552), Book 5, in the section titled "Pinzonus socis Admirantis quaerit nouas insulas," p. 1108; this is also the image copied by Gerard Mercator in his world map of 1569, which is reproduced in facsimile in Gerard Mercator's Map of the World (1569) in the Form of an Atlas in the Maritiem Museum 'Prins Hendrik' at Rotterdam (Rotterdam, 1961); and now as Atlas van der Wereld: De wereldkaart va Gerard Mercator uit 1569 (Zutphen: Walberg Pers, 2011). It should be remarked that the image of the opossum in the 1522 (Strasbourg), 1525 (Strasbourg), 1535 (Lyon), and 1541 (Vienna) editions of Ptolemy's Geography is essentially identical to that on the Carta marina, so images of opossums that seem similar to Waldseemüller's may have derived from one of these editions, rather than from the Carta marina.
} 


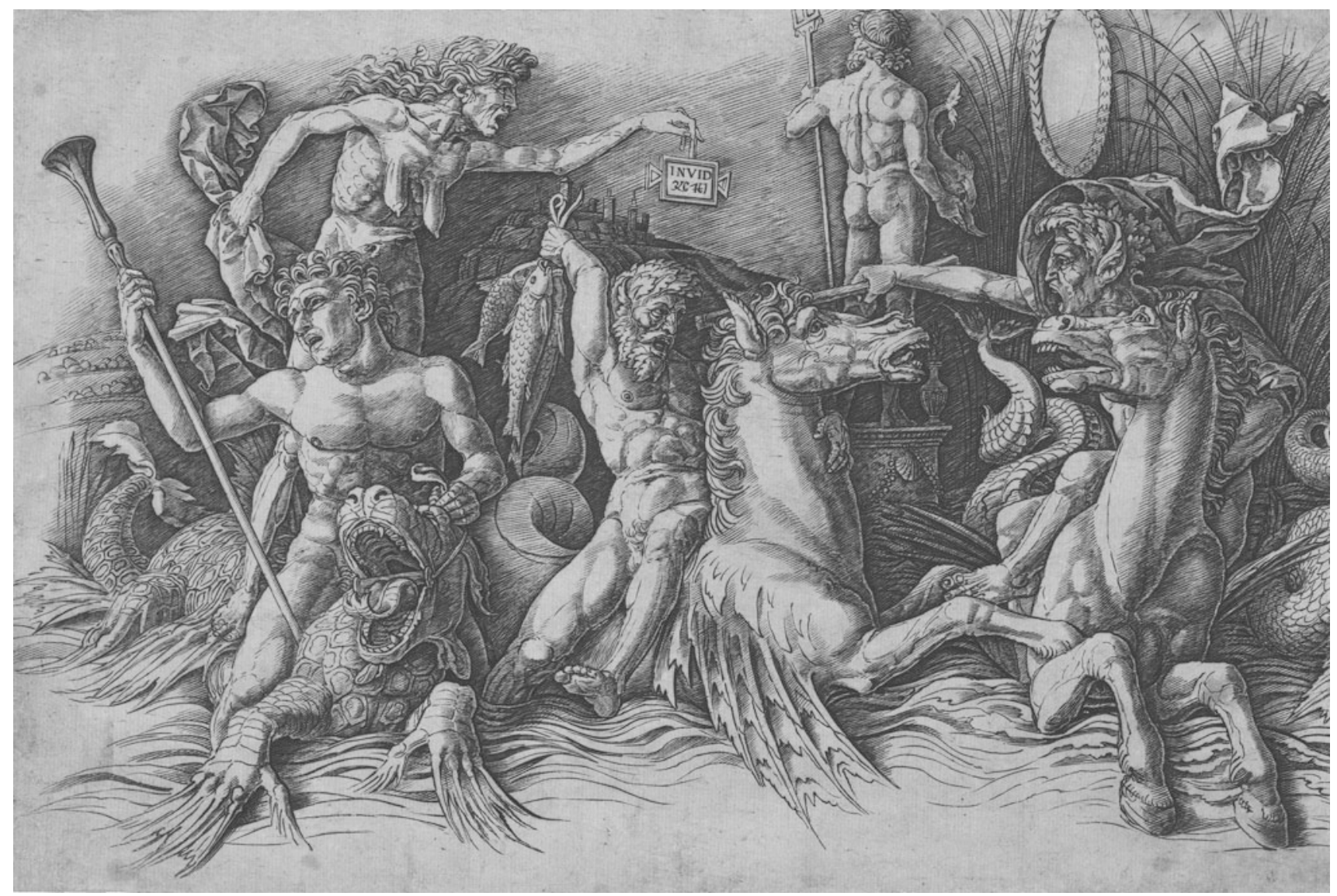

Fig. 1.8 Detail showing a god riding a sea monster from Andrea Mantegna's Battle of the Sea Gods, c. 1485-88. Washington DC, National Gallery of Art, 1984.53.1. Courtesy of the National Gallery of Art

walrus is a huge animal, the size of an elephant, and it has two long teeth which are quadrangular, and lacks joints in its legs. It is found in the northern promontories of Norway, and they travel together in groups of two hundred animals.

There is at least one discussion of a walrus by a medieval author, namely Albertus Magnus in his On Animals, ${ }^{12}$ but Waldseemüller did not make use of Albertus. ${ }^{113}$ The word Waldseemüller uses for the walrus, morsus, is usually held to have entered European literature in 1517, in Maciej of Miechów's Tractatus de duabus Sarmatiis. ${ }^{114}$ In fact, William Caxton used it in 1480 in his Chronicles of England ${ }^{115}$ _ but certainly Waldseemüller's is among the earliest uses of it. On the one hand, it is clear that Waldseemüller (or his unknown iconographical source, if there was one) made the image from a vague description that emphasized the creature's elephant-like tusks and size, rather than on the basis of seeing a walrus. On the other hand, Waldseemüller's text about the animal is surely based on information derived from an examination of a walrus, as no other known early document mentions the walrus's quadrangular tusks. ${ }^{116}$ The image and text pertaining to the walrus thus contain a mixture of good information and extrapolation, a common characteristic of attempts to interpret incomplete reports about unfamiliar things.

\footnotetext{
${ }^{112}$ See Albertus Magnus, De animalibus libri XXVI, nach der Cölner Urschrift, ed. Hermann Stadler (Münster: Aschendorff, 1916), vol. 2, p. 1525; and Albertus Magnus, On Animals: A Medieval Summa Zoologica, trans. Kenneth F. Kitchell Jr., and Irven Michael Resnick (Baltimore: Johns Hopkins University Press, 1999), vol. 2, p. 1671.

${ }^{113}$ There is also an interesting allusion to the walrus in Pletho's treatise Correction of Certain Errors made by Strabo; the Greek text is edited by Aubrey Diller, "A Geographical Treatise by Georgius Gemistus Pletho," Isis 27.3 (1937), pp. 441-451; and it is translated in Milton V. Anastos, "Studies in Pletho," Ph.D. Dissertation, Harvard University, 1940, pp. 68-163, with the passage about the walrus on p. 152.

${ }^{114}$ Valentin Kiparsky, "L'Histoire du morse," Annales Academiae Scientiarum Fennicae, Ser. B, 73.3 (1952), pp. 1-53, at p. 6.

${ }^{115}$ William Caxton, Chronicles of England (Westminster: William Caxton, 1480), Chap. 257 on the year 1456. See also Caxton's edition of Ranulf Higden's Polycronicon (Westminster: W. Caxton, 1482), f. 423, sig. 552 recto.

${ }^{116}$ I am indebted to Klaus Barthelmess (d. 2011) for his discussions of Waldseemüller's image of the walrus and its possible sources.
} 


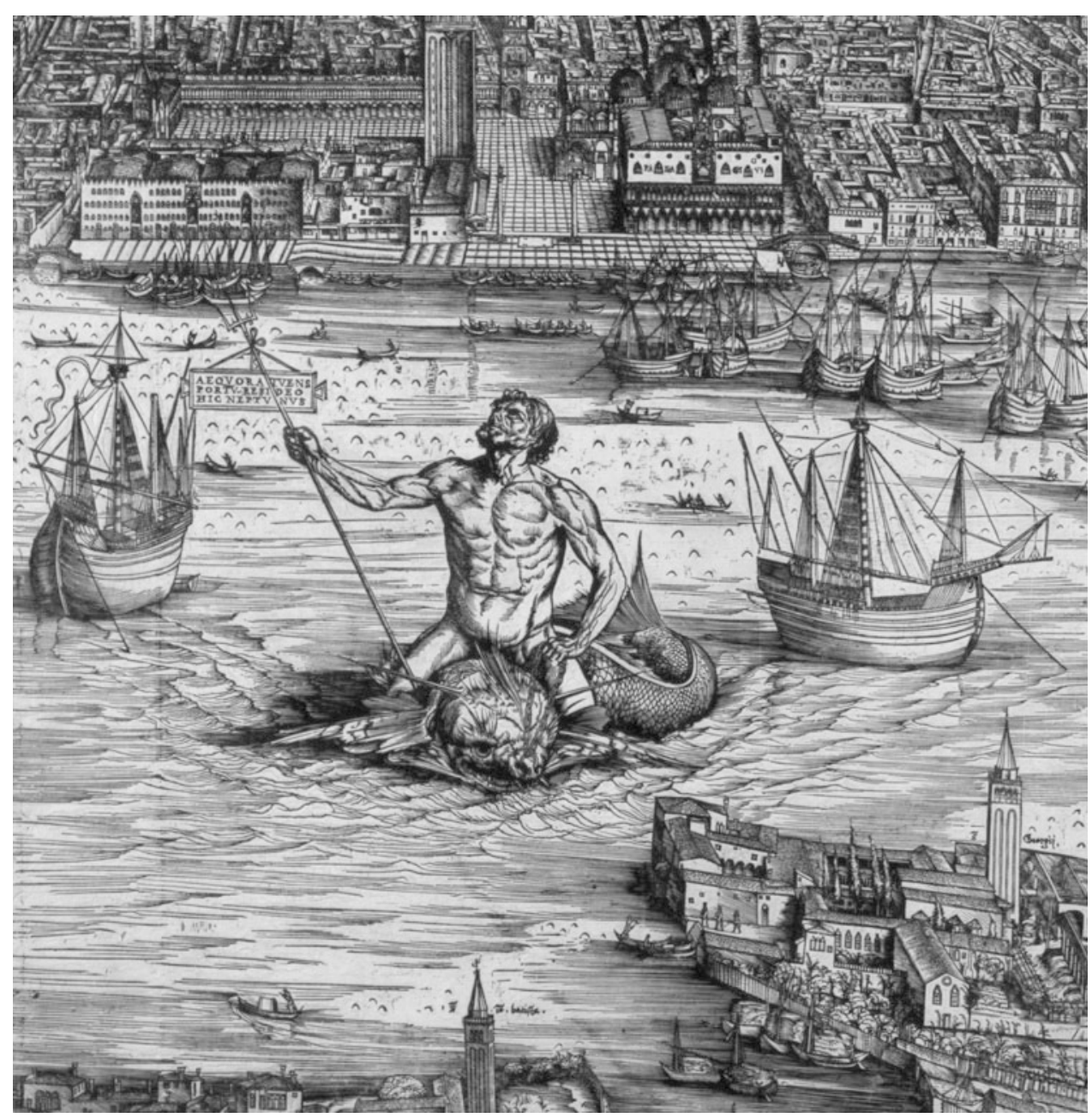

Fig. 1.9 Detail of Neptune riding a sea monster on Jacopo de' Barbari's six-sheet view of Venice of c. 1500. Chicago, Newberry Library, Novacco $8 \mathrm{f} 7$. Courtesy of the Newberry Library

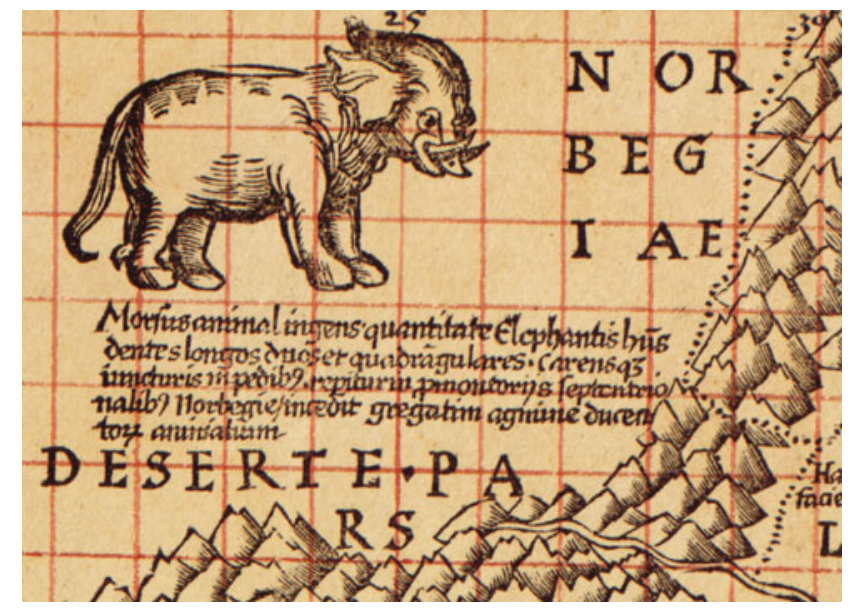

Fig. 1.10 Detail of the elephant-like walrus on Waldseemüller's Carta marina (sheet 2). Courtesy of the Library of Congress 


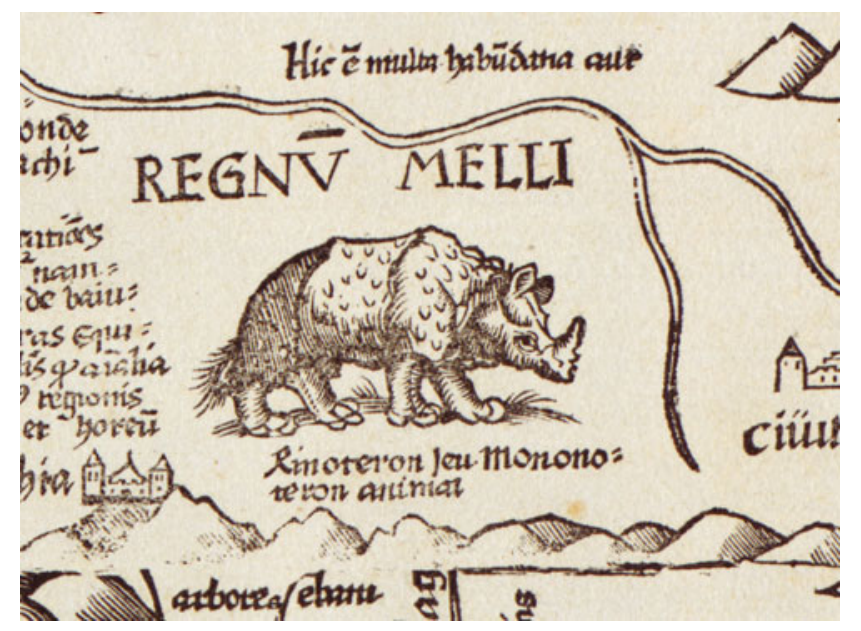

Fig. 1.11 Detail of the rhinoceros in West Africa on Waldseemüller's Carta marina (sheet 6). Courtesy of the Library of Congress

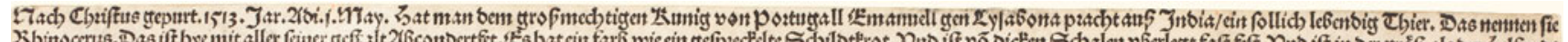

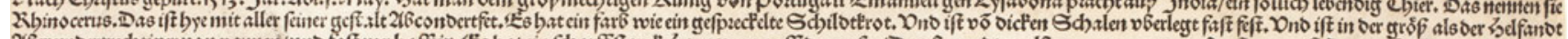

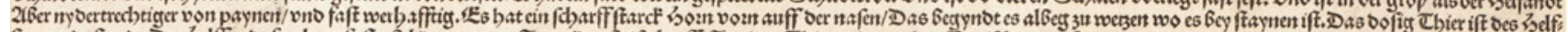

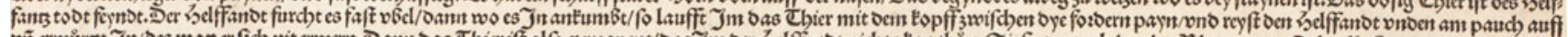

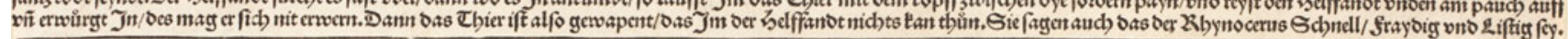

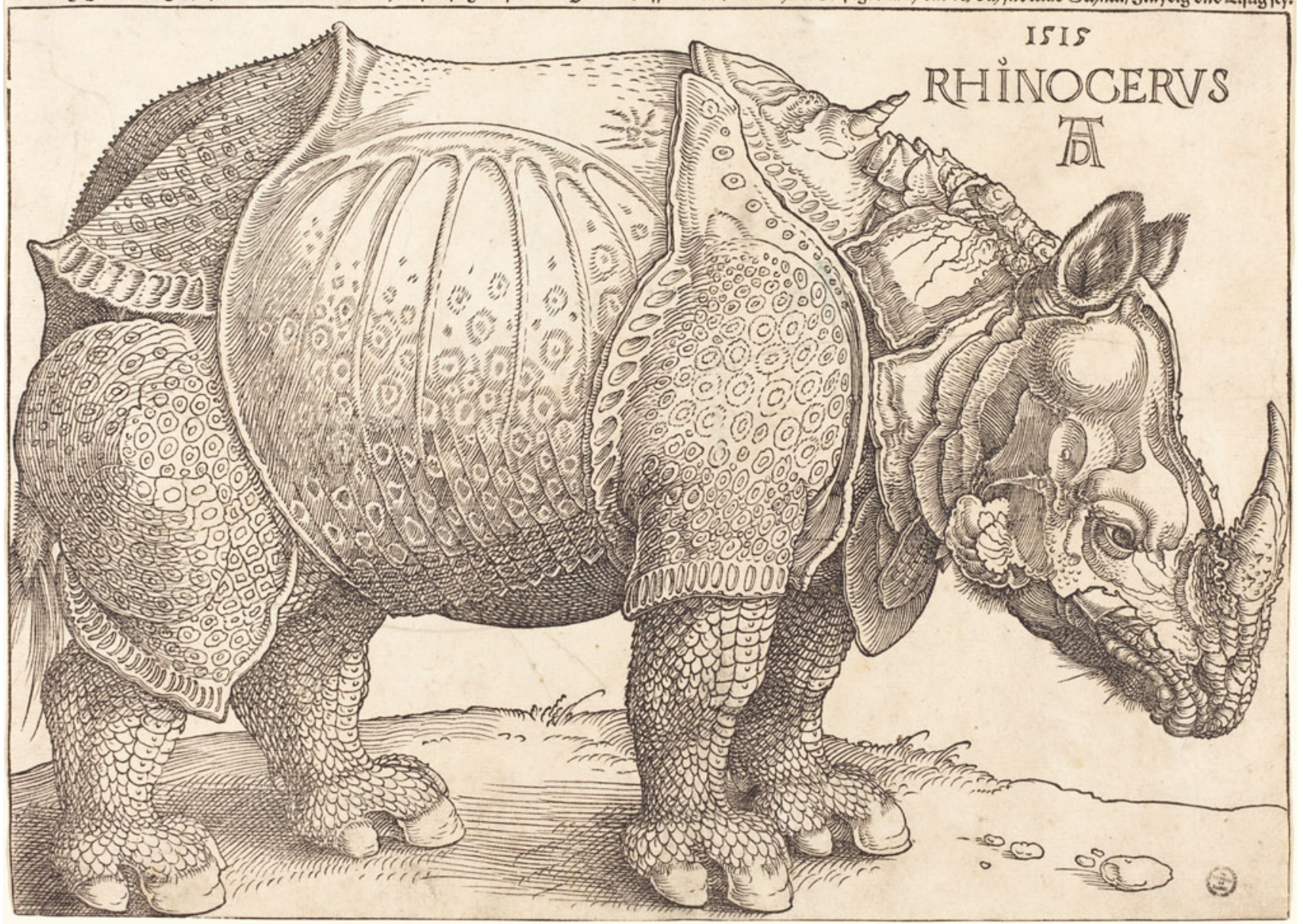

Fig. 1.12 Albrecht Dürer's print of the rhinoceros, 1515. Washington DC, National Gallery of Art, Rosenwald Collection 1964.8.697. Courtesy of the National Gallery of Art, Washington DC 
Fig. 1.13 Hans Burgkmair's print of the rhinoceros, 1515. Vienna, Grafische Sammlung Albertina, Inv. DG1934/123. Courtesy of the Albertina Museum, Vienna

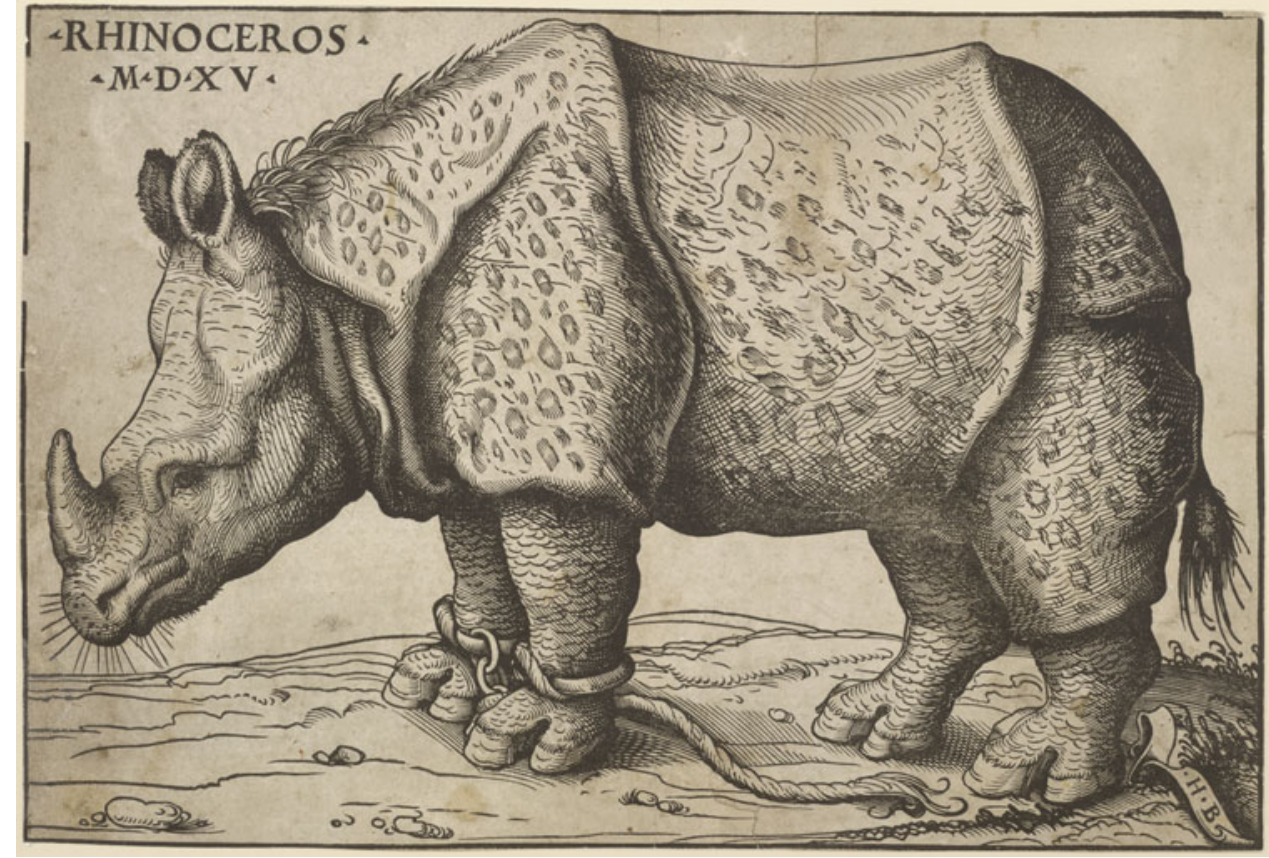

In West Africa (sheet 6), Waldseemüller shows a small image of a rhinoceros (Fig. 1.11), and this is another instance where he was using the most recent iconographical sources available. In 1514 Sultan Muzafar II of Gujarat had presented a rhinoceros to Afonso de Albuquerque, the governor of Portuguese India. Albuquerque sent the rhinoceros to King Manuel of Portugal, ${ }^{117}$ and Albrecht Dürer made an influential print depicting the animal in 1515 (Fig. 1.12). ${ }^{118}$ Waldseemüller used as his model not Dürer's print, however, but a different one, also made in 1515, by Hans Burgkmair, that survives in only one copy (Fig. 1.13). ${ }^{119}$ The images of the rhinoceroses are similar in the two artists' prints, but there are differences, and those differences indicate that Waldseemüller used Burgkmair's print: in particular, Dürer shows hard plating and a small ancillary horn on the crest of the creature's neck where Burgkmair places hair-and it is hair that we see in Waldseemüller's image. It has been suggested that Dürer might have been involved in the engraving of the Carta marina, ${ }^{120}$ but given that Waldseemüller used Burgkmair's image of the rhinoceros rather than Dürer's, this seems unlikely.

In northeastern Asia, specifically in northern India at the bottom of sheet 4, is an image of sati or suttee, the Hindu practice whereby a widow burned herself to death on the funeral pyre of her husband. This custom very much surprised Western visitors to India, and there are legends on the subject on earlier maps, for example the metal Borgia mappamundi from the first half of the fifteenth century, ${ }^{121}$ and Andreas Walsperger's mappamundi of $1448 .{ }^{122}$ The image on the Carta

\footnotetext{
${ }^{117}$ On the history of this rhinoceros see A. Fontoura da Costa, Les déambulations du rhinocéros de Modofar, roi de Cambaye, de 1514 à 1516 (Lisbon: Division de Publications et Bibliothèque, Agence Générale des Colonies, 1937); and Silvio A. Bedini, "The Ill-Fated Rhinoceros," in The Pope's Elephant (Nashville: J. S. Sanders \& Company, 1998), pp. 111-136.

${ }^{118}$ On Dürer's print of the rhinoceros see F. J. Cole, “The History of Albrecht Dürer's Rhinoceros in Zoological Literature," in A. E. Underwood, ed., Science, Medicine, and History (London: Oxford University Press, 1953), pp. 337-356; Donald Lach, Asia in the Making of Europe, vol. 2, bk. 1, A Century of Wonder: The Visual Arts (Chicago: University of Chicago Press, 1970), pp. 158-172; and T. H. Clarke, "The First Lisbon or 'Dürer' Rhinoceros of 1515,' in his The Rhinoceros from Dürer to Stubbs, 1515-1799 (London: Sotheby's Publications, 1986), pp. 16-27.

${ }^{119}$ The surviving copy of Burgkmair's print is in Vienna, Graphische Sammlung Albertina, Inv. DG1934/123. For discussion of it see Lach, Asia in the Making of Europe (see note 118), vol. 2, bk. 1, p. 164 and plate 120; Clarke, "The First Lisbon or 'Dürer' Rhinoceros" (see note 118), pp. 2425; and Jim Monson, "The Source for the Rhinoceros," Print Quarterly 21.1 (2004), pp. 50-53.

${ }^{120}$ For the suggestion that Dürer was involved in the production of the Carta marina see Joseph Fischer and Franz Ritter von Wieser, Die älteste Karte mit dem Namen Amerika (see note 9), p. 19; and Johnson, Carta marina (see note 21), p. 27.

${ }^{121}$ The Borgia mappamundi is in the Biblioteca Apostolica Vaticana, Borgia XVI, and is described and reproduced in Destombes, Mappemondes (see note 29), pp. 239-241 and plate 29. For the legend about sati see A. E. Nordenskiöld, "Om ett aftryck från XV:de seklet af den i metall graverade världskarta, som förvarats i kardinal Stephan Borgias museum i Velletri, Med 1 facsimile," Ymer 11 (1891), pp. 83-92, at 90; the map is reproduced between 130 and 131 .

${ }^{122}$ Walsperger's map is in the Biblioteca Apostolica Vaticana, MS Pal. Lat. 1362 B. For the legend about sati see Konrad Kretschmer, "Eine neue mittelalterliche Weltkarte der vatikanischen Bibliothek," Zeitschrift der Gesellschaft für Erdkunde 26 (1891), pp. 371-406, esp. 398. The article is reprinted in Acta Cartographica 6 (1969), pp. 237-272.
} 


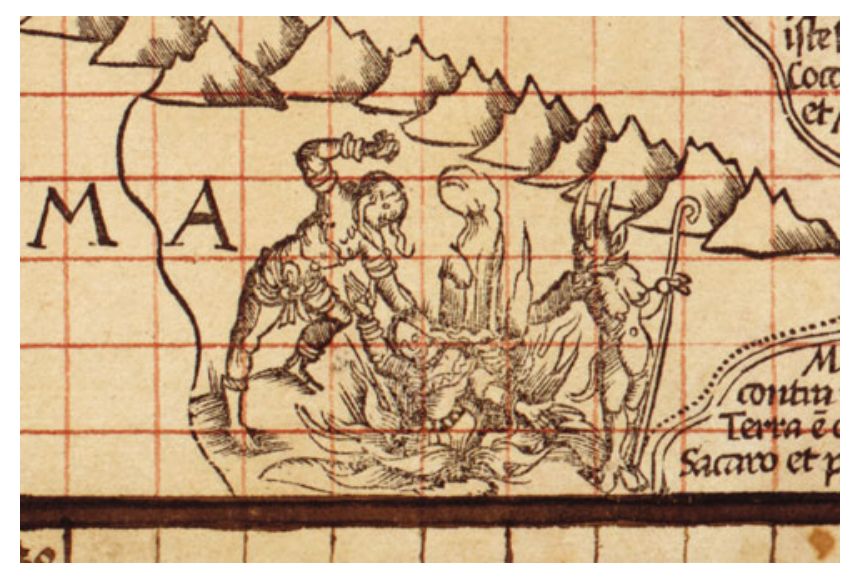

Fig. 1.14 The image of suttee or sati on Waldseemüller's Carta marina (sheet 4). Courtesy of the Library of Congress

Fig. 1.15 Jörg Breu's woodcut image of suttee or sati from the 1515 edition of Varthema's travels. Munich, Bayerische Staatsbibliothek, Rar. 894, f. 51r. Courtesy of the Bayerische Staatsbibliothek

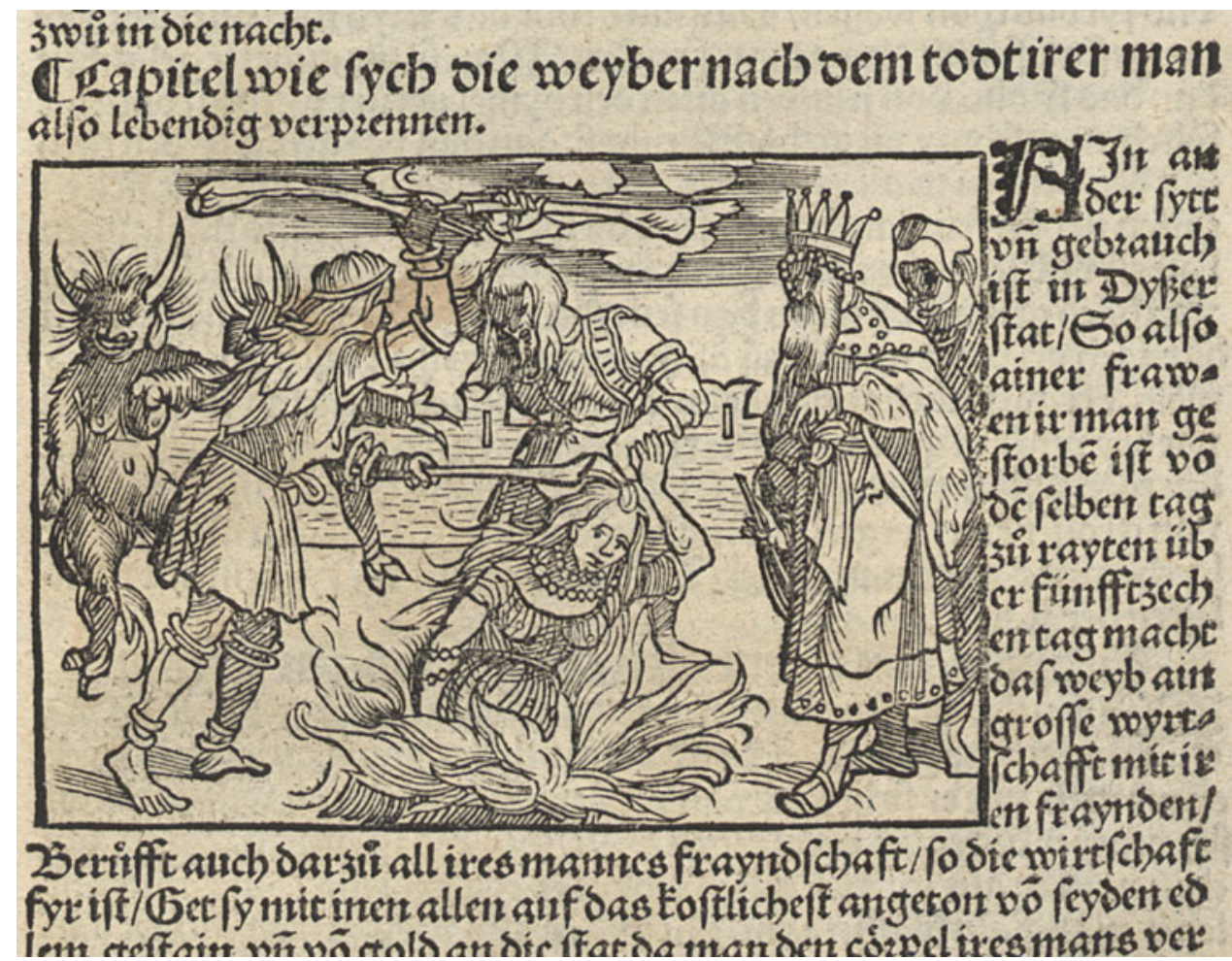

marina (Fig. 1.14) shows a woman who has leapt into a fire pit, with a man standing over her and about to strike her with something in his hand, no doubt so that she will die sooner; on the right a horned devil stands looking on. No legend accompanies the scene, but it illustrates a passage in Varthema about the practice of sati in the city of Tarnassari. Varthema describes the fire pit, the beating of the woman with sticks and balls of pitch, and the participation of men clothed like devils. ${ }^{123}$ Waldseemüller's scene here was clearly inspired by that in the first illustrated edition of Varthema, which has

\footnotetext{
${ }^{123}$ See Lodovico de Varthema, The Travels of Ludovico di Varthema in Egypt, Syria, Arabia Deserta and Arabia Felix, in Persia, India, and Ethiopia, A.D. 1503 to 1508, Translated from the Original Italian Edition of 1510... by John Winter Jones and Edited, with Notes and an Introduction, by George Percy Badger (London: The Hakluyt Society, 1863), pp. 206-208.
} 
Fig. 1.16 Jörg Breu's woodcut image of Medina from the 1515 edition of Varthema's travels. Munich, Bayerische Staatsbibliothek, Rar. 894, f. 9v. Courtesy of the Bayerische Staatsbibliothek

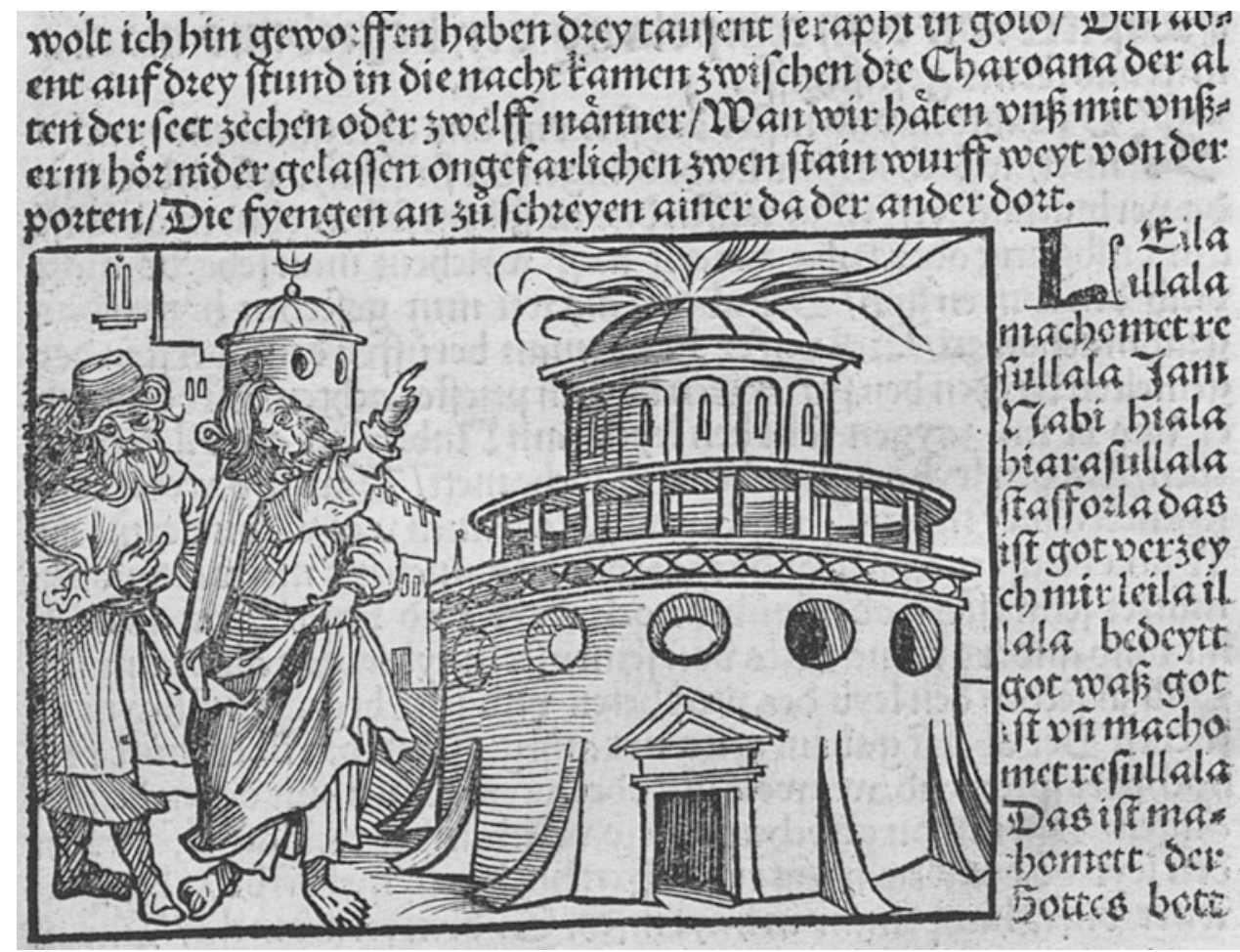

woodcuts by Jörg Breu ${ }^{124}$ and was published in $1515,{ }^{125}$ just one year before the Carta marina (Fig. 1.15): in this scene two men instead of one are beating down the woman, and a king and noble are present, but in other respects the scenes are quite similar, particularly the poses of the women and the depiction of the flames. Once again, Waldseemüller was using a recent iconographical source, and the evidence from these images gives us a window into Waldseemüller's workshop, for we now know that the cartographer had a copy of the 1515 edition of Varthema on his bookshelf.

Waldseemüller used this same edition of Varthema as the source for two other images on his map. On f. 9v of the book there is an image of the mosque of Medina, with Varthema himself on the far left, and his guide beside him (Fig. 1.16). The guide points to the flames emanating from the top of the building, which he claims indicate the presence of the prophet's body. ${ }^{126}$ This image of Medina, with its buttresses, windows, and other features, is used by Waldseemüller with very few changes to depict Mecca on the Carta marina (Fig. 1.17). The cartographer removes the flames issuing from the building's roof, and replaces them, in effect, with an Islamic crescent which he may have borrowed from the building to the left in the image in Varthema. Waldseemüller's choice to use an image of Medina for Mecca was perhaps guided by a desire to use the example he had of supposedly Islamic architecture for the more famous city; but certainly his use of this image demonstrates again his interest in giving his map a rich and accurate iconographical program from recent sources.

The important trading center of Calicut in India, mentioned above, is the only city in eastern Asia to bear a flag, and the flag is a curious one: it is of a black devil or demon (Fig. 1.18). The allusion is to the worship of devils that Varthema says

\footnotetext{
${ }^{124}$ For discussion of Breu's work see Robert Stiassny, "Jörg Breu von Augsburg," Zeitschrift für Christliche Kunst 7 (1894), pp. 101-120; Campbell Dodgson, "Beiträge zur Kenntnis des Holtzschnittwerks Jörg Breus," Jahrbuch der Preussischen Kuntsammlungen 21 (1900), pp. 192214; Campbell Dodgson, "Jörg Breu als Illustrator des Ratdoltschen Offizin: Nachtrag," Jahrbuch der Preussischen Kunstsammlungen 24 (1903), pp. 335-337; and H. Roettinger, “Zum Holzschnittwerke Jörg Breus des Älteren,” Repertorium für Kunstwissenschaft 31 (1908), pp. 48-62. The woodcuts for the Varthema cycle are reproduced in Max Geisberg, Die deutsche Buchillustration in der ersten Hälfte des XVI Jahrhunderts (Munich: Hugo Schmidt Verlag, 1930-32), vol. 1.

${ }^{125}$ The illustrated edition in question is Varthema, Die Ritterlich und lobwirdig rayß... (see note 69), with the illustration of sati on $\mathrm{f}$. 51r. For discussion of the program of illustration see Stephanie Leitch, "Recuperating the Eyewitness: Jörg Breu's Images of Islamic and Hindu Culture in Ludovico de Varthema's Travels (Augsburg: 1515)," in her Mapping Ethnography in Early Modern Germany: New Worlds in Print Culture (Basingstoke and New York: Palgrave Macmillan, 2010), pp. 101-145, esp. 128-131 on the image of sati.

${ }^{126}$ Varthema was one of first Europeans to realize the falsity of the common medieval myth that Mohammad's sarcophagus was at Mecca, when in fact he was buried in Medina: for discussion of this myth see Sandra Sáenz-López Pérez, "La peregrinación a La Meca en la Edad Media a través de la cartografía occidental," Revista de poética medieval 19 (2007), pp. 177-218. The scene of Varthema in Medina in the 1515 edition of Varthema's travels is discussed by Leitch, "Recuperating the Eyewitness" (see note 125), p. 108.
} 


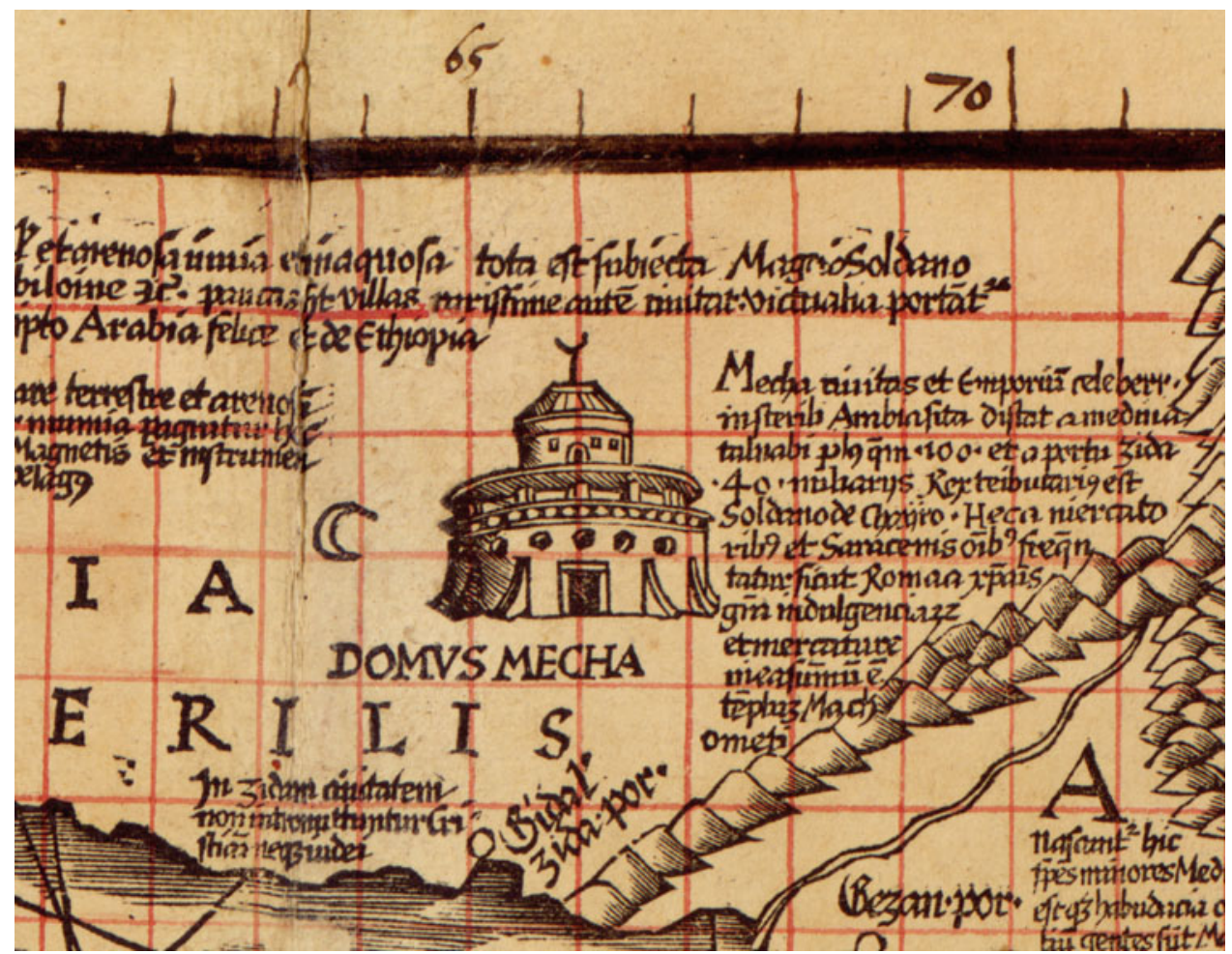

Fig. 1.17 Detail of Mecca on Waldseemüller's Carta marina (sheet 7). Courtesy of the Library of Congress

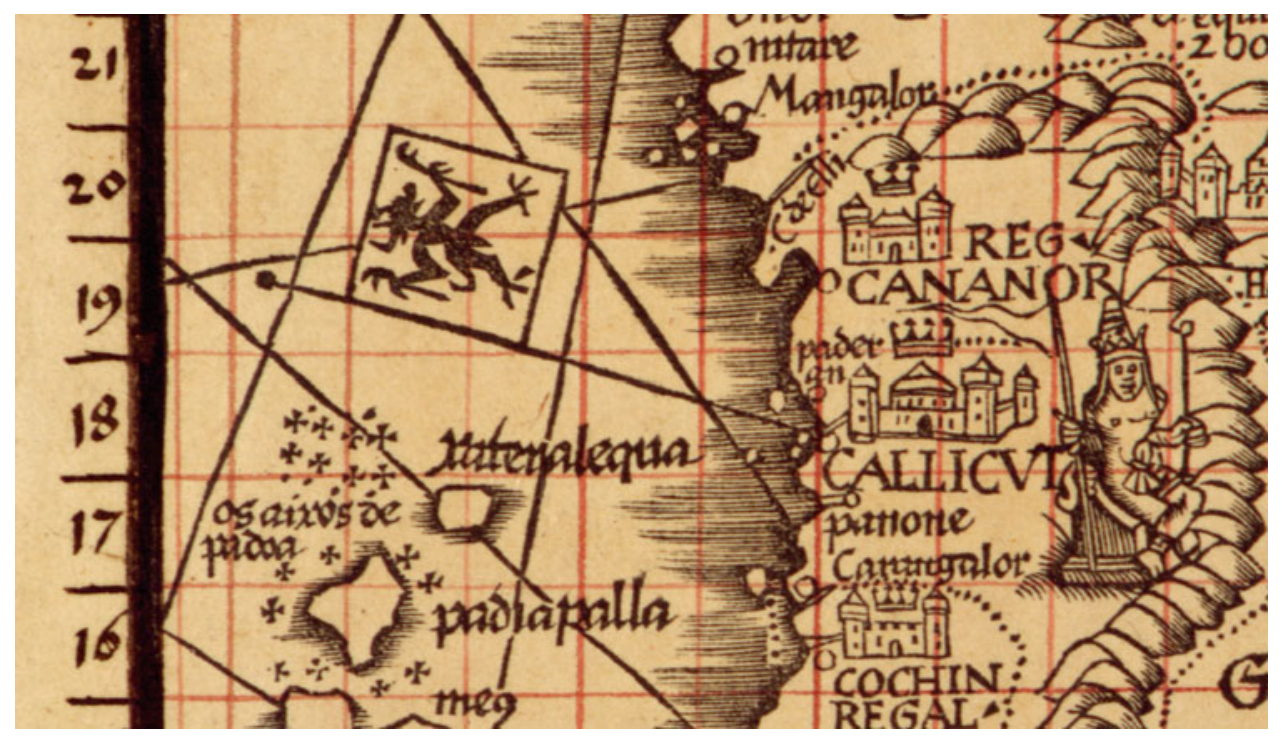

Fig. 1.18 Image of Calicut, India, with its flag displaying a demon on Waldseemüller's Carta marina (sheet 8). Courtesy of the Library of Congress 
Fig. 1.19 Jörg Breu's woodcut image of the devil of Calicut, India, from the 1515 edition of Varthema's travels. Munich, Bayerische Staatsbibliothek, Rar. 894 , f. 35r. Courtesy of the Bayerische Staatsbibliothek

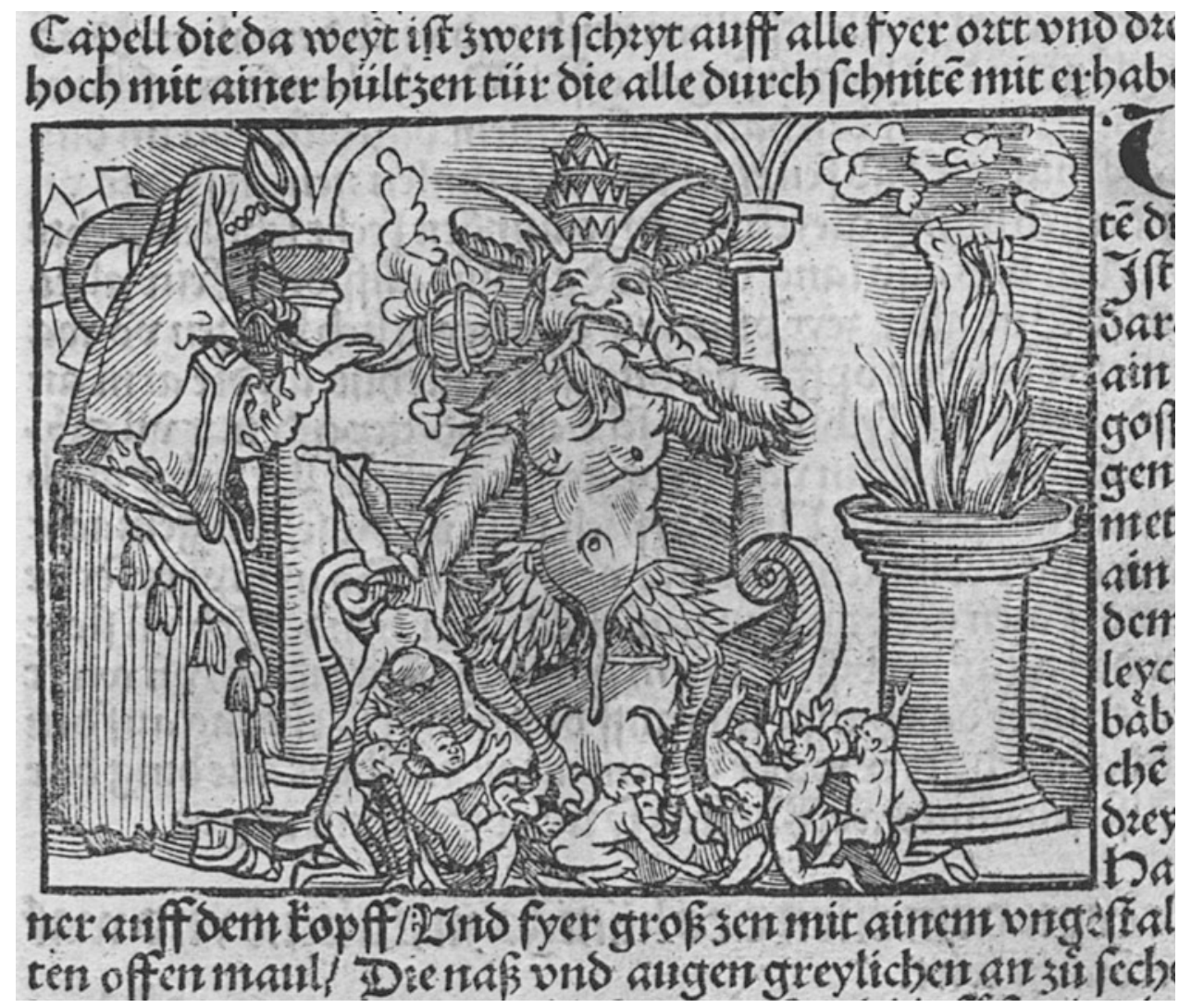

took place in Calicut, ${ }^{127}$ though this is merely a misunderstanding of Hindu art, ${ }^{128}$ and the image on the flag is a simplification of an image of the devil supposedly worshipped in Calicut in the same 1515 edition of Varthema (Fig. 1.19).

On sheet 8 , in southwestern India, there is a curious image of an Indian king with a crown on his turban who is standing rather than sitting on a throne (Fig. 1.20). Waldseemüller borrowed this image from another recent source, the 1509 edition of Balthasar Springer's account of Francisco de Almeida's voyage to India, which was illustrated by Hans Burgkmair (Fig. 1.21). Waldseemüller has rotated the man to the left, added the crown to his turban to make him a king, and shortened the handle of his weapon, but there can be no doubt where he obtained the image. Waldseemüller used Burgkmair's image of this Indian man a second time on the map, in West Africa (sheet 6), to illustrate a king in the delta of the Senegal River (Fig. 1.22). The king stands almost with his back to us, and Waldseemüller seems to have borrowed this stance from that of a figure in another of Burgkmair's illustrations of Springer's narrative, namely the man shading the king in the fold-out Triumphus Regis Gosci sive Gutschmin, or Triumph of the King of Cochin (Kochi, India) (Fig. 1.23). ${ }^{129}$ It is interesting that Waldseemüller did not hesitate to use an image of an Indian man to illustrate an African, particularly as the 1509 edition of Springer's book has images of Africans that Waldseemüller could have copied. ${ }^{130}$ One reason might have been that the

\footnotetext{
${ }^{127}$ On the alleged worship of devils in Calicut see The Travels of Ludovico di Varthema, trans. Jones (see note 123), pp. 136-138.

${ }^{128}$ For analysis of this misperception of Hindu art see Partha Mitter, Much Maligned Monsters: History of European Reactions to Indian Art (Oxford: Clarendon Press, 1977), pp. 16-20; Joan-Pau Rubiés, "Ludovico de Varthema: The Curious Traveller at the Time of Vasco da Gama and Columbus," in his Travel and Ethnology in the Renaissance: South India through European Eyes, 1250-1625 (Cambridge and New York: Cambridge University Press, 2000), pp. 125-163, esp. 155-156; Leitch, "Recuperating the Eyewitness" (see note 125), pp. 132-135; and Jennifer Spinks, "The Southern Indian 'Devil in Calicut' in Early Modern Northern Europe: Images, Texts and Objects in Motion," Journal of Early Modern History 18.1-2 (2014), pp. 15-48.

${ }^{129}$ For discussion of the Triumph scene see Götz Pochat, "Triumphus Regis Gosci sive Gutschmin. Exoticism in French Renaissance Tapestry," Gazette des Beaux-Arts, 6th ser., 82, 105 (1973), pp. 305-310; reprinted in Götz Pochat, Kunst, Kultur, Ästhetik: gesammelte Aufsätze (Vienna, Berlin, and Münster: LIT, 2007), pp. 279-286.

${ }^{130}$ For discussion of the images of Africans in the 1509 edition of Springer's narrative see Jean Michel Massing, "Hans Burgkmair's Depiction of Native Africans," RES: Anthropology and Aesthetics 27 (1995), pp. 39-51, who notes (p. 51) that "Burgkmair's woodcuts... were, for decades, the only representations of Africans and Indians based on visual information rather than mere literary testimony." Also see Ronald Singer and Werner Jopp, “The Earliest Illustration of Hottentots: 1508," The South African Archaeological Bulletin 22.85 (1967), pp. 15-19; and Renate Kleinschmid, "Balthasar Springer. Eine quellenkritische Untersuchung," Mitteilungen der Anthropologischen Gesellschaft in Wien 96-97 (1967), pp. 147-190.
} 


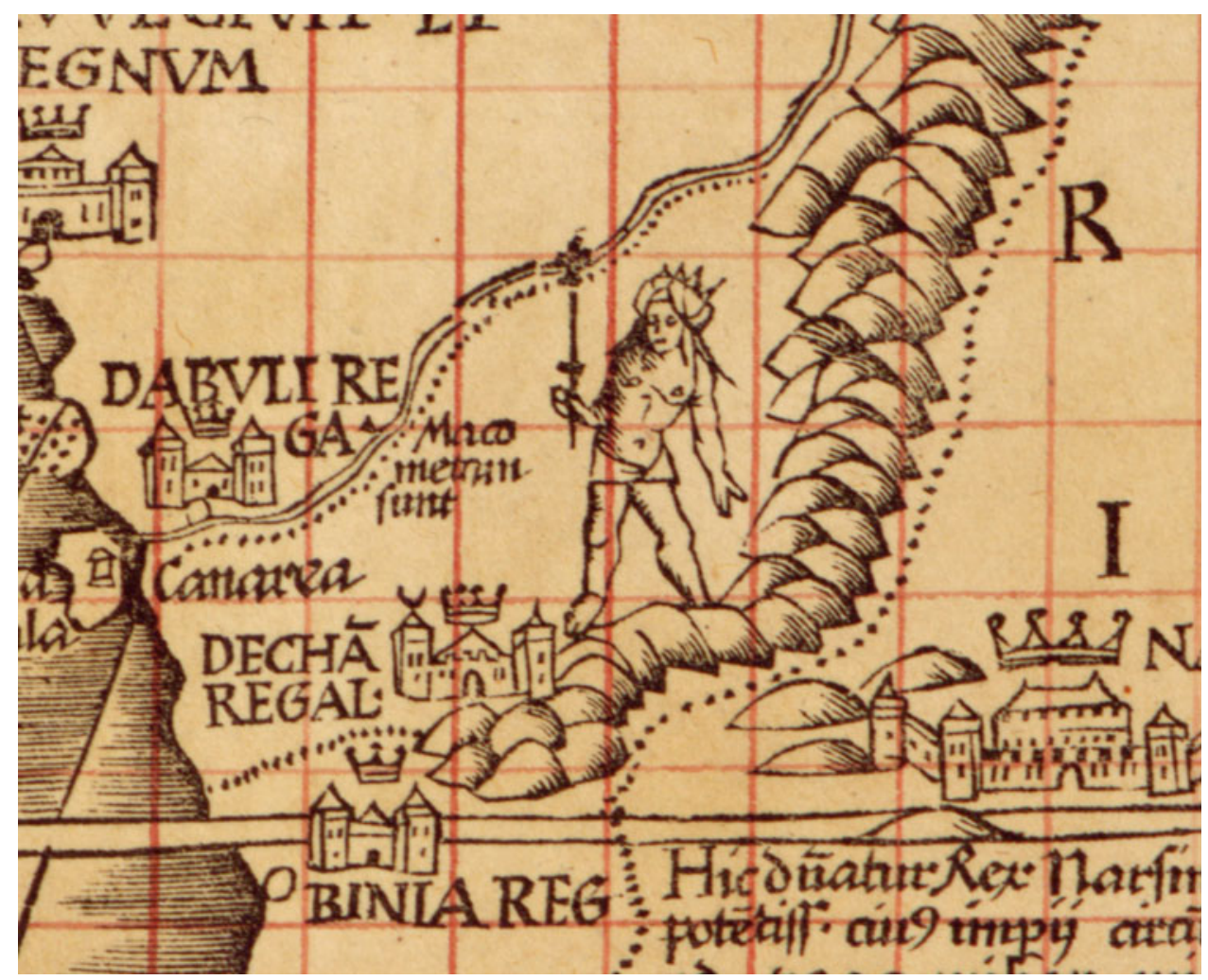

Fig. 1.20 Detail of a king in southwestern India on Waldseemüller's Carta marina (sheet 8). Courtesy of the Library of Congress

Africans in Springer's book are naked, and Waldseemüller's colleague Matthias Ringmann, who had worked closely with him on the Cosmographiae introductio, the 1511 Carta itineraria Europae with its accompanying booklet, and the 1513 edition of Ptolemy, ${ }^{131}$ had written against the illustration of full-frontal nudity in $1509 .{ }^{132}$ On the other hand, the natives in southern Africa on the 1507 map are naked, and it would not have been difficult to add clothes to Burgkmair's naked figures, so the matter is not clear.

We know that Waldseemüller had the Caverio chart in his workshop, but he twice alludes to having more than one nautical chart at his disposal. In the Cosmographiae introductio he says that he has followed nautical charts (plural) particularly with regard to the newly discovered lands, ${ }^{133}$ and in the long text block on sheet 9 of the Carta marina he says that eo que in maris descriptionibus vulgarem fuerimus \& approbatissimam nauticarum tabularum notificationes insequuti, "as far as the depiction of the oceans, I have followed the commonly used and the most approved nautical charts and their indications" (plural). It seems very likely that some of the illustrations on the Carta marina were inspired by nautical chart legends or illustrations - legends or illustrations that do not appear on the Caverio chart —and an examination of these images can give us information about the other chart or charts that Waldseemüller had.

\footnotetext{
${ }^{131}$ Franz Laubenberger (trans. Steven Rowan), "The Naming of America," The Sixteenth Century Journal 13.4 (1982), pp. 91-113, with some corrections in Christine R. Johnson, "Renaissance German Cosmographers and the Naming of America," Past \& Present 191 (2006), pp. 3-43. ${ }^{132}$ See Matthias Ringmann, Grammatica figurata (Saint-Dié: s.n., 1509), ff. 12v-13r; there is a facsimile edition of the work, Franz Ritter von Wieser, ed., Grammatica figurata des Mathias Ringmann (Philesius Vogesigena) in Faksimiledruck (Strassburg: Heitz, 1905). For discussion of the book see Jean-Claude Margolin and Diana Wormuth, "Mathias Ringmann's Grammatica figurata, or, Grammar as a Card Game," Yale French Studies 47 (1972), pp. 33-46.

${ }^{133}$ See Joseph Fischer and Franz von Wieser in The 'Cosmographiae introductio' of Martin Waldseemüller, Chap. 9, p. xxxvii (Latin), and p. 78 (English); and Hessler, The Naming of America (see note 7), p. 106. The passage is quoted below on p. 39.
} 


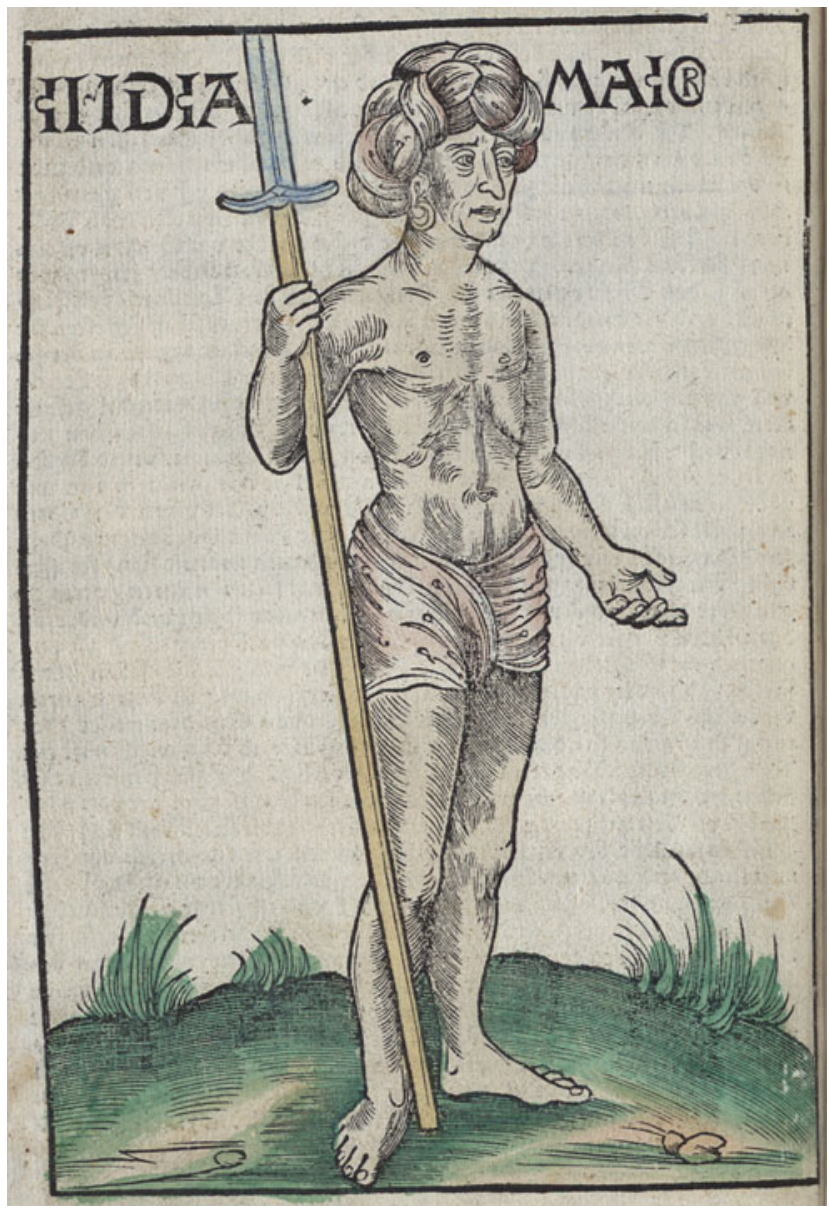

Fig. 1.21 Hans Burgkmair's woodcut illustration of an Indian man in the 1509 edition of Balthasar Springer's account of Francisco de Almeida's voyage to India. Munich, Bayerische Staatsbibliothek, Rar. 470, f. 12v. urn:nbn:de:bvb:12-bsb00045403-6. Courtesy of the Bayerische Staatsbibliothek

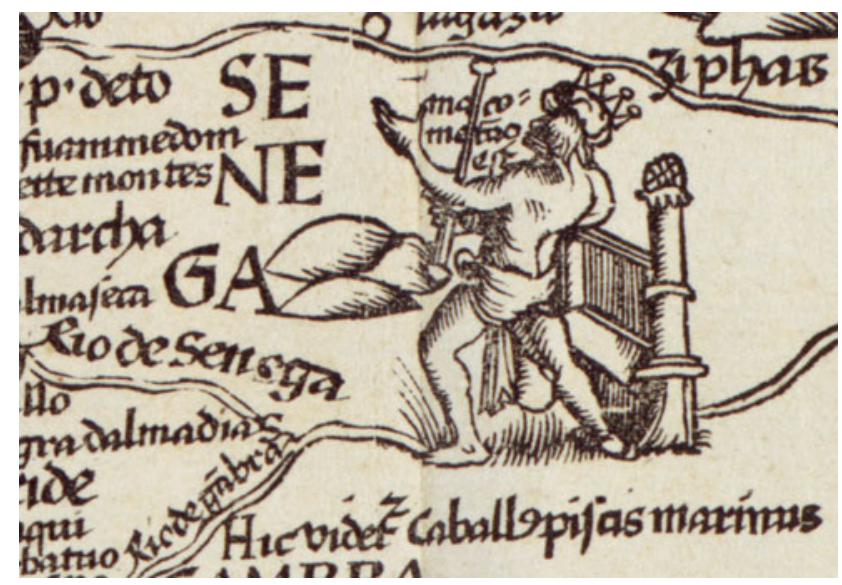

Fig. 1.22 Detail of a man in Senegal on Waldseemüller's Carta marina (sheet 6). Courtesy of the Library of Congress 


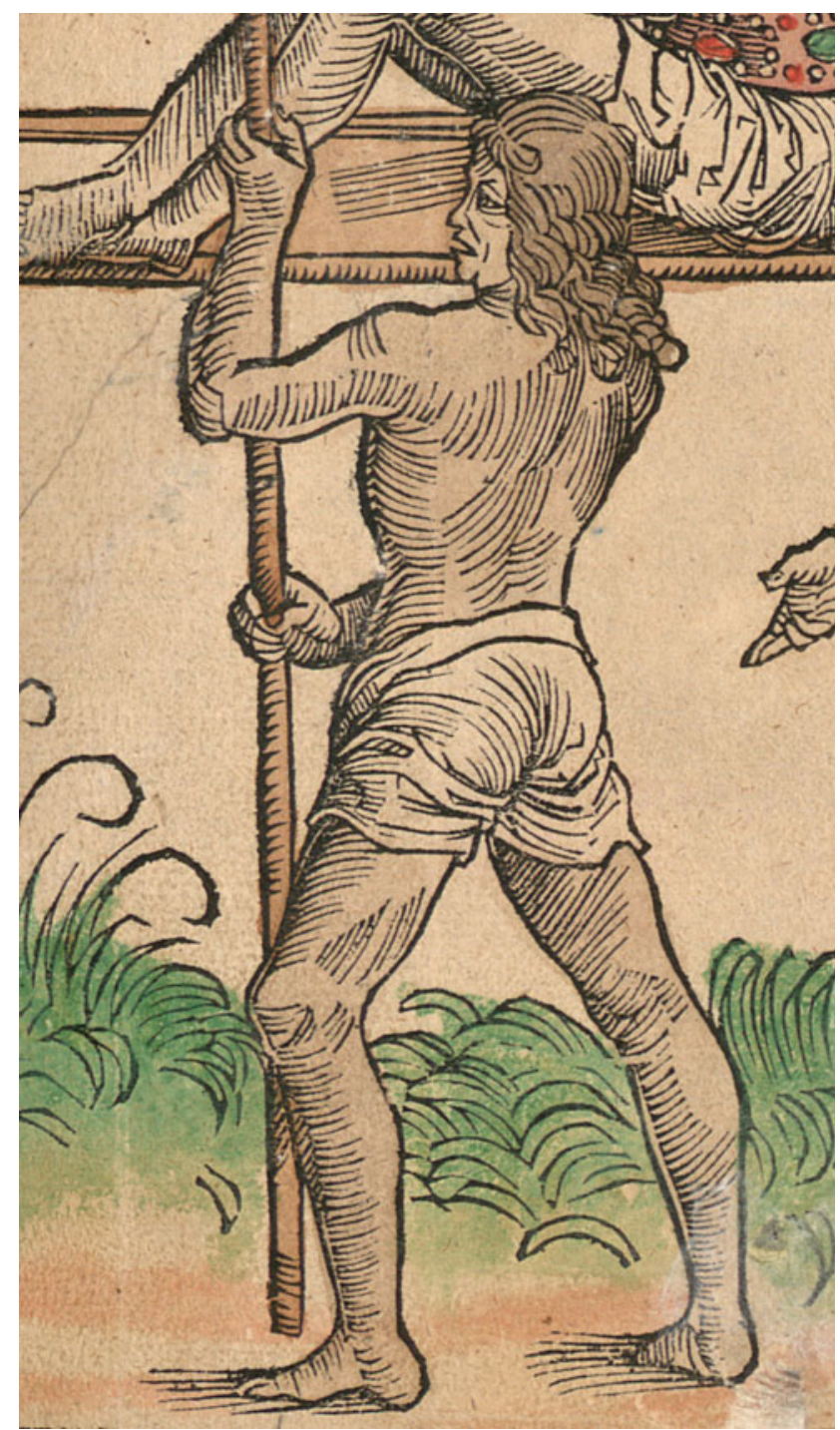

Fig. 1.23 Detail of the fold-out Triumphus Regis Gosci in the 1509 edition of Balthasar Springer's account of Francisco de Almeida's voyage to India. Munich, Bayerische Staatsbibliothek, Rar. 470, ff. 2v-3r. urn:nbn:de:bvb:12-bsb00045403-6. Courtesy of the Bayerische Staatsbibliothek

At the top of sheet 7 of the Carta marina there is a small image of Moses kneeling before Mount Sinai and receiving from God the two tablets with the commandments written on them (Fig. 1.24). I do not know of an earlier nautical chart that has a similar image of Moses, but many nautical charts have a legend that probably inspired Waldseemüller to include this scene. The Pizzigani chart of $1367,{ }^{134}$ for example, has a legend that reads (in very idiosyncratic Latin) Mons Sinay quo dominus jesus a de moyss instrudebat et ey legem cunferebat propter populum, "Mount Sinai where Lord Jesus or God instructed Moses and gave him the law for the people." ${ }^{135}$ The legend on the Catalan Atlas of $1375^{136}$ is similar, Mont de Sinai en lo

\footnotetext{
${ }^{134}$ The 1367 Pizzigani chart is in Parma, Biblioteca Palatina, Carta nautica no. 1612, and there is a good hand-drawn facsimile of the chart in Edme-François Jomard, Les monuments de la géographie (Paris: Duprat, 1842-1862), nos. 44-49; and a photographic reproduction in Guglielmo Cavallo, ed., Cristoforo Colombo e l'apertura degli spazi: mostra storico-cartografica (Rome: Istituto Poligrafico e Zecca dello Stato, Libreria dello stato, 1992), vol. 1, pp. 432-433. There is a good digital reproduction of the chart in Pujades, Les cartes portolanes (see note 31), on the accompanying CD, number C13. The Library of Congress has a hand-painted copy of the map made by Agostinho Sardi in Parma in 1802, which is very briefly described in Walter W. Ristow and R. A. Skelton, Nautical Charts on Vellum in the Library of Congress (Washington, DC: The Library, 1977), p. 2. There is also a hand-painted copy of the map made in 1827, which is in Vienna, Österreichische Nationalbibliothek, Cod. Ser. Nov. 4676.

${ }^{135}$ Transcribed by Mario Longhena, "La carta dei Pizigano del 1367 (posseduta dalla Biblioteca Palatina di Parma)," Archivio storico per le province Parmensi, series 4, vol. 5 (1953), pp. 25-130, at 106.

${ }^{136}$ For references on the Catalan Atlas see note 38.
} 


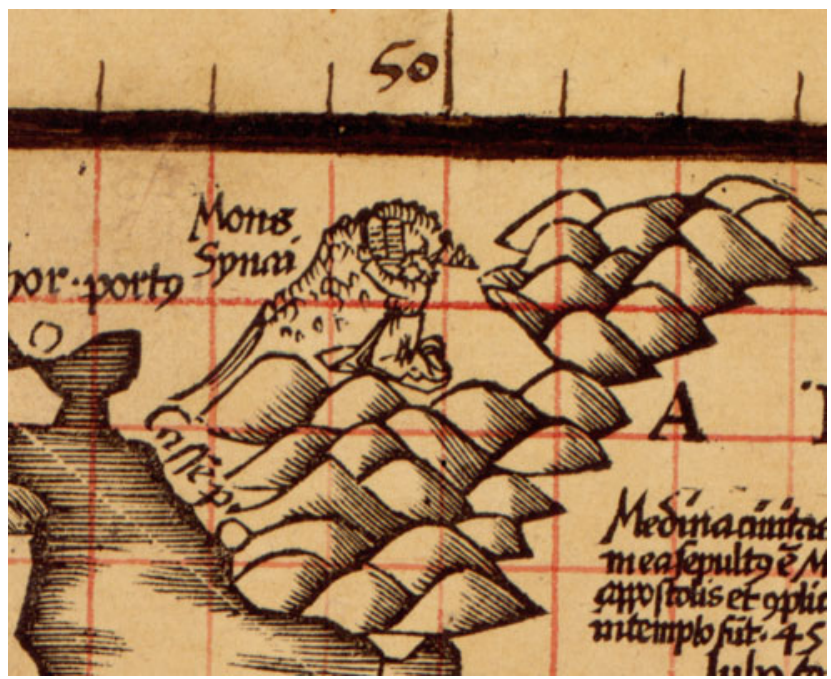

Fig. 1.24 Detail of Moses kneeling before Mount Sinai and receiving from God the two Tablets of the Law, from Waldseemüller's Carta marina (sheet 7). Courtesy of the Library of Congress

qual Déu dona la Ley a Moyssés, "Mount Sinai where God gave the law to Moses."137 Similar legends appear on many other nautical charts, including some sixteenth-century works by Ottomano Freducci, such as London, British Library, Add. MS 11548 , made in $1529 .{ }^{138}$ It seems likely, then, that such a legend inspired Waldseemüller to add an image of Moses to his map; Waldseemüller may have drawn iconographic inspiration from the scene of Moses receiving the laws in Hartmann Schedel's Liber chronicarum (Nuremberg: Anton Koberger, 1493), f. 30v (Fig. 1.25), as in both cases Moses is receiving the tablets with his hands gripping them from the sides, ${ }^{139}$ but there are so many representations of this scene that it is impossible to be certain that the Liber chronicarum was the source. ${ }^{140}$

On sheet 3 of the Carta marina just west of the Caspian (which is labeled Mare Abacuc...) there is a short legend that reads Arach mons super quam requieuit Archa noe, "Mount Ararat, upon which Noah's Ark rested," above which there is a small image of a ship on the mountains (see Fig. 1.26 and Legend 3.12). Isidore, Etymologiae 14.3.35, Marco Polo, and Pierre d'Ailly mention that Noah's Ark can be found on some mountains in Armenia, but they do not give the mountains' name. ${ }^{141}$ The case is much the same with Odoric of Pordenone, ${ }^{142}$ and Varthema does not mention Noah's Ark. But there is a nautical chart tradition

\footnotetext{
${ }^{137}$ The legend on the Catalan Atlas is transcribed in Mapamundi del año 1375 (Barcelona: S.A. Ebrisa, 1983), p. 45.

${ }^{138}$ See Chet Van Duzer, "Nautical Charts, Texts, and Transmission: The Case of Conte di Ottomano Freducci and Fra Mauro," Electronic British Library Journal, article 6 (2017), pp. 1-65, at 44-45. The article is available at http://www.bl.uk/eblj/2017articles/article6.html.

${ }^{139}$ The likelihood that Waldseemüller used Schedel's Liber chronicarum as a source for the image of Moses is increased somewhat by the fact that he used the same book as a source for his image of a cynocephalus in India: see Van Duzer, "A Northern Refuge of the Monstrous Races" (see note 90), p. 226.

${ }^{140}$ For example, there is an illustration of Moses receiving the tablet with both hands in John Mandeville, Johannes Montevilla der wyffaren de Ritter (Strasburg: Mathias Hupfuff, 1501), fol. D 2 r, and is reproduced in La Gravure d'illustration en Alsace au XVIe siècle (Strasbourg: Presses universitaires de Strasbourg, 1992-2000), vol. 2, p. 176. Incidentally there are representations of Moses receiving the tablets from God in some of the manuscript atlases by Battista Agnese: see Henry R. Wagner, "The Manuscript Atlases of Battista Agnese," Papers of the Bibliographical Society of America 25 (1931), pp. 1-110, at 35. One of these atlases is Venice, Museo Correr, Port. 1, which is Wagner's \#55, pp. 91-93; this atlas has been reproduced in facsimile as Atlante nautico di Battista Agnese, 1553 (Venice: Marsilio, 1990), where the map in question is reproduced on plate 27. Another such atlas is New Haven, Beinecke Rare Book and Manuscript Library, MS 560, map 21: images of all of the maps in this atlas are available through the Beinecke's Digital Library at http://beinecke.library.yale.edu/digitallibrary/.

${ }^{141}$ Evidence from Waldseemüller's 1507 map indicates that he was not using the Latin edition of Polo published c. 1484, De consuetudinibus et condicionibus Orientalium regionum (Gouda: Gerard Leeu, c. 1483-1485), but rather a manuscript similar to Naples, Biblioteca Nazionale Vittorio Emanuele III, Vind. lat. 50. The text of this manuscript has been published in Marco Polo, Marka Pavlova z Benátek, Milion: Dle jediného rukopisu spolu s prilusnym zakladem latinskym, ed. Justin Václav Prásek (Prague: Nákl. Ceské akademie císare Frantiska Iozefa, 1902), and the passage on Noah's Ark is in Book 1, Chap. 13, pp. 17-18. For the passage in Yule's translation see Marco Polo, The Book of Ser Marco Polo, Book 1, Chap. 4, vol. 1, p. 46. For the passage in Pierre d'Ailly see Ymago mundi, ed. Edmond Buron (Paris: Maisonneuve frères, 1930), vol. 1, pp. 302-03.

${ }^{142}$ For the passage in Odoric see Henry Yule, ed. and trans., Cathay and the Way Thither: Being a Collection of Medieval Notices of China, revised by Henri Cordier (London: The Hakluyt society, 1913-16), vol. 2, pp. 101-102 (English), 280 (Latin), and 338 (Italian).
} 


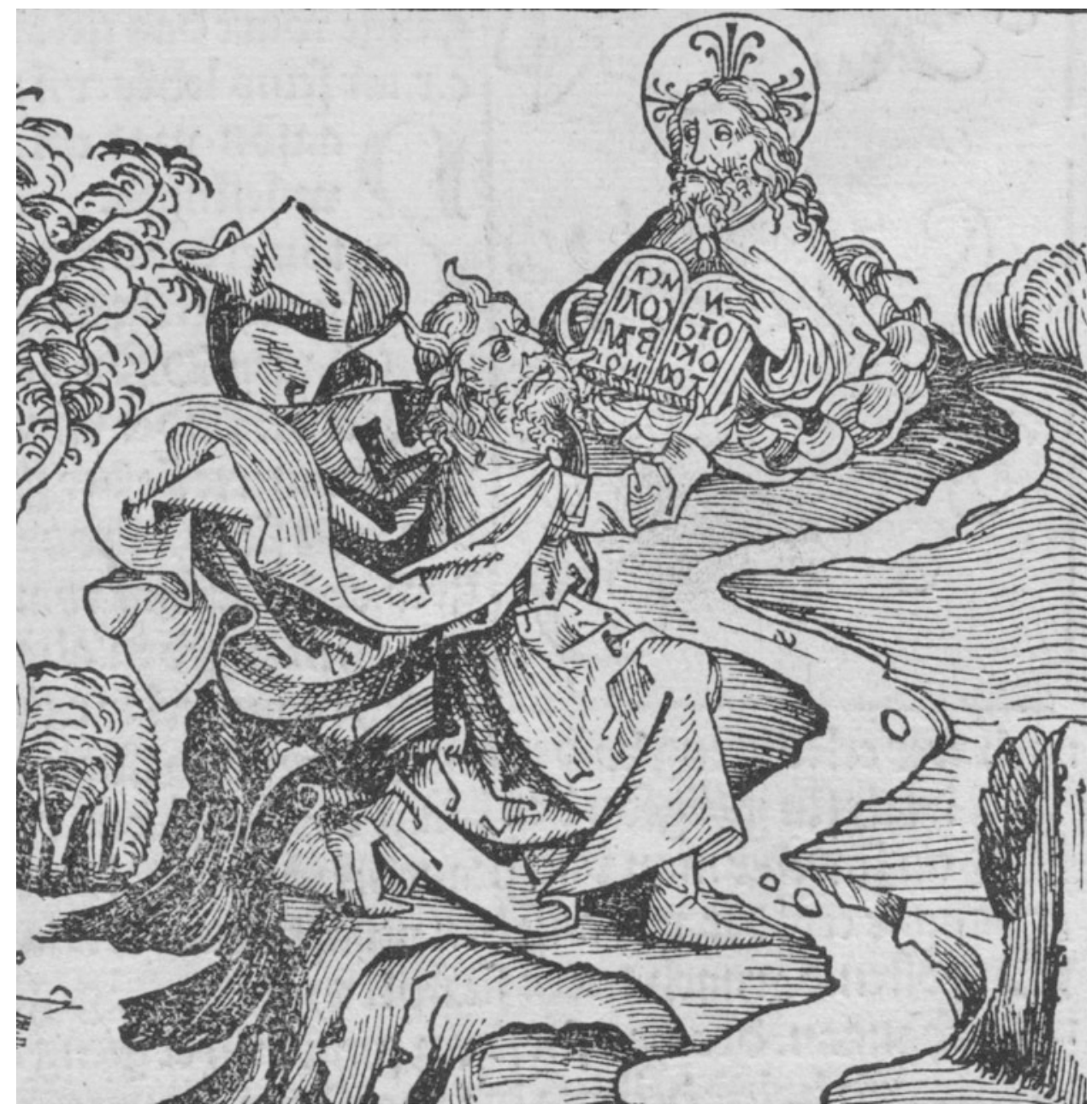

Fig. 1.25 Moses receiving from God the two Tablets of the Law, from the Hartmann Schedel's Buch der Croniken (Nuremberg, 1493), f. 30v. Library of Congress, Rare Book and Special Collection Division, Rosenwald Collection 166. Courtesy of the Library of Congress

of illustrating Noah's ark on a pair of mountains together with a brief text identifying the ship and the mountains, very much as we have on Waldseemüller's Carta marina. ${ }^{143}$ The earliest surviving nautical chart that has a representation of Noah's Ark is that of Angelino Dulcert of $1339,{ }^{144}$ where the illustration is accompanied by the text Archa de Noe. Mons Ararat in quo permansit Archa Noe post diluuium, "Noah's Ark. Mount Ararat on which Noah's Ark remained after the Flood." 145 Very similar texts appeared on later luxury nautical charts including the Pizzigani chart of $1367,{ }^{146}$ Catalan Atlas of $1375,{ }^{147}$ Mecia de

\footnotetext{
${ }^{143}$ Noah's Ark is also illustrated on some mappaemundi, such as the Psalter map, the Ebstorf map, and the Hereford map, but the legend accompanying the image on the Carta marina is closer to what we find on nautical charts, and Waldseemüller shows no other signs of having used a large mappamundi. For the legend on the Ebstorf map see Hartmut Kugler, Die Ebstorfer Weltkarte (Berlin: Akademie Verlag, 2007), vol. 1, p. 76, 24.A1, and vol. 2, p. 135, 24/1; and for the legend on the Hereford map see Scott D. Westrem, The Hereford Map: A Transcription and Translation of the Legends with Commentary (Turnhout: Brepols, 2001), pp. 106-107, \#224. For other appearances of Noah's Ark on mappaemundi see Konrad Miller, Mappaemundi: Die ältesten Welkarten (Stuttgart, 1895-98), vol. 3, subtitled "Die kleineren Weltkarten," pp. 6, 32, 93, 119, 145, and 148; there is also an image of the Ark, but without descriptive text, on Fra Mauro's mappamundi of c. 1455: see Piero Falchetta, Fra Mauro's World Map (Turnhout: Brepols, 2006), pp. 498-499, *1679.

${ }^{144}$ The 1339 Dulcert chart is in Paris, Bibliothèque nationale de France, Ge B 696 Rés. It is reproduced in Cavallo, Cristoforo Colombo e l'apertura degli spazi (see note 134), vol. 1, pp. 164-165, with descriptive text on pp. 162-163; and on a larger scale in Gabriel Marcel, Choix de cartes et de mappemondes des XIVe et XVe siècles (Paris: E. Leroux, 1896); and in Pujades, Les cartes portolanes (see note 31), pp. 120-121 and on the accompanying $\mathrm{CD}$, number $\mathrm{C} 8$.

${ }^{145}$ The illustrations of and texts about Noah's Ark on nautical charts are surveyed by Sandra Sáenz-López Pérez, "Imagen y conocimiento del mundo en la Edad Media a través de la cartografía Hispana," Ph.D. Dissertation, Universidad Complutense de Madrid, 2007, vol. 1, pp. 475-478. ${ }^{146}$ On the 1367 Pizzigani chart see note 134 .

${ }^{147}$ On the Catalan Atlas see note 38.
} 
Viladestes's chart of $1413,{ }^{148}$ the chart of Joan de Viladestes of $1428,{ }^{149}$ and the Catalan-Estense map of c. $14600^{150}$; there is also an image of Noah's Ark on an elaborately decorated chart made by Grazioso Benincasa in 1482, but without the brief explanatory text. ${ }^{151}$ When the descriptive text does appear, it is quite similar to that on Waldseemüller's Carta marina. On nautical charts the Ark is represented either as a chest, in a curious pyramidal shape, ${ }^{152}$ or as a building, whereas Waldseemüller's image is distinctly a ship, ${ }^{153}$ but it would be quite natural for Waldseemüller to change the image he found in a nautical chart to something more shiplike. ${ }^{154}$ Thus we can be quite certain that in addition to the Caverio chart, Waldseemüller had a heavily illustrated luxury nautical chart.

In northeastern Asia on the Carta marina Waldseemüller has an image of a man riding a deer, certainly a reindeer, and a brief legend that says magis Septentrionales equitant ceruos, "In the far north they ride deer" (see Legend 4.17). On his 1507 map in the same area Waldseemüller has a legend about Balor Regio that derives from Marco Polo, and mentions that the inhabitants ride deer. ${ }^{155}$ The image and legend on the Carta marina are in essentially the same location as the legend on the 1507 map, but the image comes from a nautical chart illustration of an inhabitant of Scandinavia riding a reindeer-that is, Waldseemüller has transplanted a nautical chart image relating to Scandinavia to a location that accords with what Marco Polo says about northeastern Asia. There are just a few nautical charts that have an illustration of a Scandinavian man riding a reindeer: Mecia de Viladestes's chart of $1413^{156}$; the Vatican Borgia XVI metal mappamundi from the first half of the fifteenth century, which uses nautical chart data ${ }^{157}$; the anonymous nautical chart which is Florence, Biblioteca Nazionale

\footnotetext{
${ }^{148}$ The 1413 Mecia de Viladestes chart is in Paris, Bibliothèque nationale de France, Rés. Ge AA 566; it is illustrated in Michel Mollat and Monique de la Roncière, Sea Charts of the Early Explorers: 13th to 17th Century, trans. L. le R. Dethan (New York: Thames and Hudson, 1984), chart 12; and in Pujades, Les cartes portolanes (see note 31), pp. 202-203, and on the accompanying CD, number C30.

${ }^{149}$ Joan de Viladestes's chart of 1428 is in Istanbul, Topkapi Sarayi, H. 1826, and is reproduced in Youssouf Kamal, Monumenta cartographica Africae et Aegypti (Cairo, 1926-51), vol. 4, fasc. 4, ff. 1456v-1457.

${ }^{150}$ The Catalan-Estense map is in Modena, Biblioteca Estense Universitaria, C. G. A. 1, and has been reproduced in facsimile, with transcription and commentary, in Ernesto Milano and Annalisa Battini, Mapamundi Catalán Estense, escuela cartográfica mallorquina (Barcelona: M. Moleiro, 1996); there is a high-resolution digital image of the map on the CD-ROM titled Antichi planisferi e portolani: Modena, Biblioteca Estense Universitaria (Modena: Il Bulino; and Milan: Y. Press, 2004), and a good study of it in Konrad Kretschmer, "Die katalanische Weltkarte der Biblioteca Estense zu Modena," Zeitschrift der Gesellschaft für Erdkunde zu Berlin 32 (1897), pp. 65-111 and 191-218.

${ }^{151}$ The 1482 chart by Grazioso Benincasa is Bologna, Biblioteca Universitaria, Rot. 3, and is reproduced in Cavallo, Cristoforo Colombo e l'apertura degli spazi (see note 134), vol. 1, pp. 356-357, with descriptive text on pp. 353 and 358.

${ }^{152}$ For discussion of the depiction of Noah's Ark as a chest and with a pyramidal shape in non-cartographic contexts see Marianne Besseyre, "L'iconographie de l'arche de Noé, du IIIJ au XVe siècle: du texte aux images," Thèse de l'École Nationale des Chartes, 1997, Chap. 2; the thesis is summarized in Marianne Besseyre, "L'iconographie de l'Arche de Noé du IIIe au XVe siècle: du texte aux images," in Positions des thèses soutenues par les élèves de la promotion de 1997 pour obtenir le diplôme d'archiviste-paléographe (Paris: École Nationale des Chartes, 1997), pp. 53-58.

${ }^{153}$ On the development of the iconography of Noah's Ark depicted as a ship see Maria Teresa Lezzi, "L'arche de Noé en forme de bateau: naissance d'une tradition iconographique," Cahiers de civilisation médiévale 37 (1994), pp. 301-324; and Andreina Contessa, "Noah's Ark on the Two Mountains of Ararat: The Iconography of the Cycle of Noah in the Ripoll and Roda Bibles," Word \& Image 20.4 (2004), pp. 257-270. Incidentally Noah's Ark is depicted as a ship on the fifteenth-century Zeitz mappamundi, which is Zeitz, Stiftsbibliothek MS Hist. Fol. 497, f. 48r, and is reproduced in color in Egon Klemp, Africa on Maps Dating from the Twelfth to the Eighteenth Century, trans. Margaret Stone and Jeffrey C. Stone (New York: McGraw-Hill Book Co., 1970), plate 6. For discussion and a black-and-white illustration of the map see Heinrich Winter, "A Circular Map in a Ptolemaic MS," Imago Mundi 10 (1953), pp. 15-22. There is a good discussion of depictions of Noah's Ark on maps in René Tebel, Das Schiff im Kartenbild des Mittelalters und der Frühen Neuzeit: kartographische Zeugnisse aus sieben Jahrhunderten als maritimhistorische Bildquellen (Wiefelstede: Oceanum Verlag, 2012), pp. 77-84.

${ }^{154}$ There is a boat-like image of Noah's Ark on a mountain in a manuscript of Jean Mansel's La Fleur des Histoires that was made c. 1455, namely Brussels, Bibliothèque Royale, MS 9231, f. 281v. This map is widely reproduced: see Destombes, Mappemondes (see note 29), p. 179, \#51.1 and plate 20; Monique Pelletier, ed., Couleurs de la terre: des mappemondes médiévales aux images satellitales (Paris: Bibliothèque nationale de France, 1998), p. 34 (large and in color); and Peter Barber, ed., The Map Book (New York: Walker \& Co.; and Delray Beach, FL: Levenger Press, 2005), p. 73 (large and in color).

${ }^{155}$ The legend on Waldseemüller's 1507 map reads: Balor regio. Incole istius regionis habitant in montibus sunt siluestres carent vino et blada utuntur carnibus ceruorum et equitant ceruos domesticos. For the passage in Marco Polo see Marco Polo, Marka Pavlova z Benátek, Milion: Dle jediného rukopisu spolu s prilusnym zakladem latinskym, ed. Justin Václav Prásek (Prague: Nákl. Ceské akademie císare Frantiska Iozefa, 1902), Book 1, Chap. 62, p. 62. For the passage in Yule's translation see Marco Polo, The Book of Ser Marco Polo, Book 1, Chap. 61, vol. 1, p. 269 with 271-272. Johann Schöner drew on this legend from Waldseemüller's 1507 map for a legend on his manuscript globe of 1520.

${ }^{156}$ On Mecia de Viladestes's chart of 1413 see note 148 above.

${ }^{157}$ The Borgia map is described and reproduced in Destombes, Mappemondes (see note 29), pp. 239-241 and plate 29; also see A. E. Nordenskiöld, "Om ett aftryck från XV:de seklet af den i metall graverade världskarta, som förvarats i kardinal Stephan Borgias museum i Velletri, Med 1 facsimile," Ymer 11 (1891), pp. 83-92, with the reproduction of the map between pp. 130 and 131. For a good study of the map see John Hamer, "The Borgia Map: Europe's Rise and the Re-Definition of the World," MA Thesis, University of Michigan, Ann Arbor, 1995.
} 


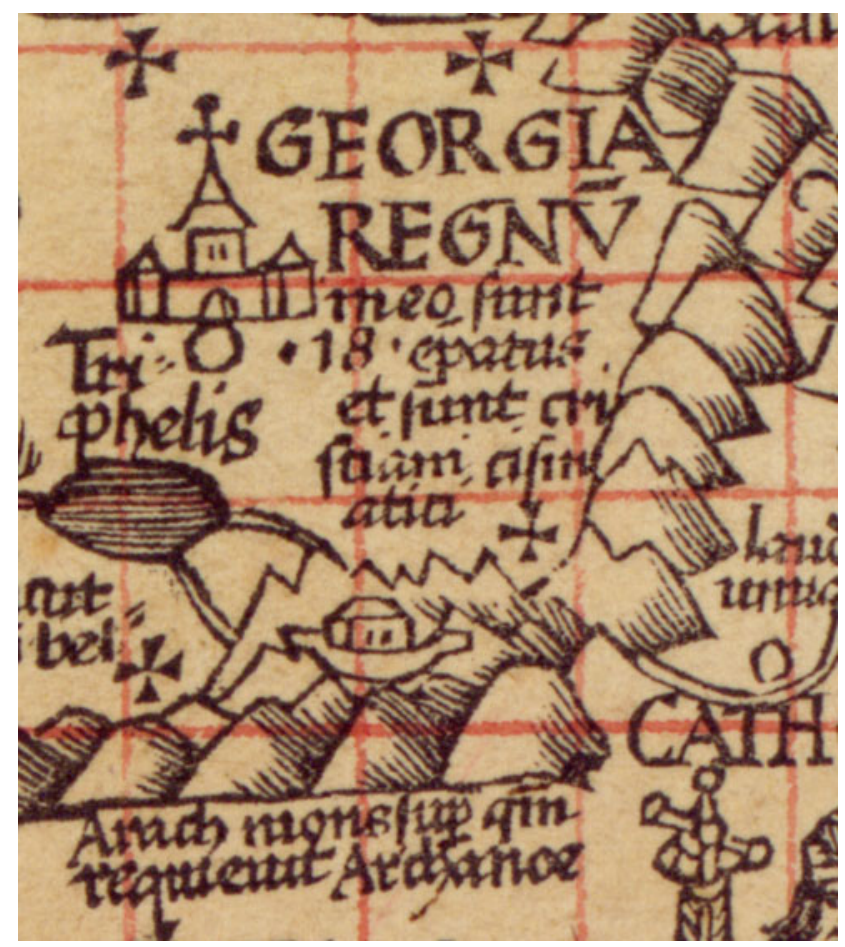

Fig. 1.26 Detail of Noah's Ark on Waldseemüller's Carta marina (sheet 3). Courtesy of the Library of Congress

Centrale, Portolano 16 (ca. 1439-1460) ${ }^{158}$; and the Catalan-Estense map (c. 1460). ${ }^{159}$ In addition, a mid fifteenth-century nautical chart which is now lost, but whose legends are preserved in a manuscript in Genoa has a text that says that in the provinces de Scachia et de Gotia.... Sunt magni venatores et equitant ceruos, "of Scachia and Gothia... they are great hunters and ride deer." 160

In addition to the evidence of images, below in my discussion of the names Waldseemüller gives to the Caspian Sea (see Legend 3.25) I will show that those names come from a nautical chart, and are most similar to the names assigned to the sea on the Catalan Atlas of 1375 and the Catalan-Estense mappamundi of c. 1460.

The images of Noah's Ark and the man riding the reindeer, and also the names of the Caspian Sea, are of particular value in shedding light on the type of nautical chart from which Waldseemüller drew these images. First it was a luxury nautical chart, as the hinterlands contained illustrations. Also, as most nautical charts show the rectangular area defined by a diagonal from the Red Sea northwest to Ireland, plus a bit more of the Atlantic, we know that Waldseemüller's chart was larger than average, as it included lands north to Scandinavia and east to Armenia (Mount Ararat), and in fact to the Caspian. In particular, the surviving charts that have the illustration of a man riding a reindeer date from 1413 to about 1460. It would not surprise me if the chart fragment of c. 1375 which is in Istanbul, Topkapi Saray, H. 1828, once contained such an illustration, ${ }^{161}$ but in any case there are no charts later than c. 1460 that have this illustration. So in addition to the quite recent and no doubt very expensive Caverio chart, Waldseemüller had an older large luxury nautical chart, on which the hinterlands were much more elaborately decorated than on the Caverio chart. This is one case in which Waldseemüller was content to make occasional use of a somewhat older source.

\footnotetext{
${ }^{158}$ Florence, BNCF Portolano 16 is reproduced in Pujades, Les cartes portolanes (see note 31), pp. 270-271, and on the accompanying CD, number C41.

${ }^{159}$ On the Catalan-Estense map see note 150 .

${ }^{160}$ The manuscript is in Genoa, Biblioteca Universitaria, MS B. I. 36. The legends in the manuscript are transcribed and translated into French in Jacques Paviot, "Une mappemonde génoise disparue de la fin du XIVe siècle," in Gaston Duchet-Suchaux, ed., L'Iconographie: études sur les rapports entre textes et images dans l'Occident médiéval (Paris: Le Léopard d'Or, 2001), pp. 69-97. Paviot indicates that the lost map is from the late fourteenth century, but as one of its legends cites Antoniotto Usodimare, it must be from 1455 or later. The legend about the reindeer is legend 7, pp. 79 (Latin) and 89 (French).

${ }^{161}$ For discussion of this chart fragment see Marcel Destombes, "Fragments of Two Medieval World Maps at the Topkapu Saray Library," Imago Mundi 12 (1955), pp. 150-152; and Philipp Billion, Graphische Zeichen auf mittelalterlichen Portolankarten (Marburg: Tektum Verlag, 2011), pp. 184-188.
} 
Waldseemüller's use of so many recent sources, both textual and iconographical, clearly reflects his ambition to create a thoroughly up-to-date image of the world. It also provides insight into the cartographer's schedule of work on the Carta marina: he was actively working on the map right until it was printed in 1516.

\subsection{The Development of Waldseemüller's Cartographic Thought}

Waldseemüller's use of Ptolemaic cartographic principles in his 1507 map and his repudiation of them in his 1516 map merit tracing in more detail. As we saw earlier, the title of the 1507 map describes an essentially Ptolemaic world map, with the addition of the New World. Waldseemüller's description of his project in the accompanying Cosmographiae introductio is similar, except that he says he was influenced not only by verbal accounts of the new discoveries but also by nautical charts $^{162}$ :

Haec pro inductione ad Cosmographiam dicta sufficiant si te modo ammonuerimus prius, nos in depingendis tabulis typi generalis non omnimodo sequutos esse Ptholomeum, presertim circa nouas terras, ubi in cartis marinis aliter animaduertimus, equatorem constituti, quam Ptholomeus foecerit. Et proinde non debent nos statim culpare qui illud ipsum notauerint. Consulto enim foecimus quod hic Ptholomeum, alibi cartas marinas sequuti sumus.

All that has been said by way of introduction to cosmography will be sufficient, if we merely advise you that in designing the sheets of our world-map we have not followed Ptolemy in every respect, particularly as regards the new lands, where on nautical charts we observe that the equator is placed otherwise than Ptolemy represented it. Therefore those who notice this ought not to find fault with us, for we have done so purposely, because here we have followed Ptolemy, and elsewhere nautical charts.

So there was some tension between the Ptolemaic and nautical chart models in the 1507 map. In fact, expressions of doubt about or criticism of Ptolemy go back to the first Latin translation of the work, which was made in 1409 by Jacopo Angeli da Scarperia, ${ }^{163}$ who mentions other authors qui et alia quedam habent quae ab auctore hoc Ptolomeo uidentur pretermissa, "who have other things which seem to have been omitted by this author, Ptolemy."164 A manuscript of Ptolemy's Geography from c. 1436-1455 shows marked influence of nautical charts, using nautical chart data for the coastlines, but Ptolemaic place names in the interior. ${ }^{165}$ Fra Mauro on his world map of c. 1455 notes that Ptolemy's information about various regions is incomplete, and declines to employ his system of latitude and longitude. ${ }^{166}$ The addition of Tabulae modernae, or modern maps, to both manuscripts and printed editions of Ptolemy represents a profound if unarticulated criticism of Ptolemy's data, ${ }^{167}$ and such maps existed in the 1486 Ulm edition of Ptolemy, of which Waldseemüller owned a copy.

\footnotetext{
${ }^{162}$ See Joseph Fischer and Franz von Wieser in The 'Cosmographiae introductio' of Martin Waldseemüller, Chap. 9, p. xxxvii (Latin), and p. 78 (English); and Hessler, The Naming of America (see note 7), p. 106.

${ }^{163}$ On Angeli da Scarperia and his translation of Ptolemy's Geography see Roberto Weiss, "Jacopo Angeli da Scarperia (c. 1360-1410/11)," in Medioevo e Rinascimento: Studi in onore di Bruno Nardi (Florence: Sansoni, 1955), vol. 2, pp. 801-827; reprinted in Weiss's Medieval and Humanist Greek: Collected Essays (Padua: Antenore, 1977), pp. 255-277.

${ }^{164}$ Jacopo Angeli's introduction was published in the Vicenza, 1475, and Bologna, [1477] editions of the Geography. The version of the introduction in Harvard University, Houghton Library, MS Typ 5, ff. 1r-2v, has been published by James Hankins in "Ptolemy's Geography in the Renaissance," in Rodney G. Dennis with Elizabeth Falsey, eds., The Marks in the Fields: Essays on the Uses of Manuscripts (Cambridge, Mass.: The Houghton Library, 1992), pp. 118-127; and reprinted in Hankins' Humanism and Platonism in the Italian Renaissance (Rome: Edizioni di storia e letteratura, 2003-), vol. 1, pp. 457-468. This text is reprinted and translated into English by Charles Burnett in Zur Shalev and Charles Burnett, eds., Ptolemy's 'Geography' in the Renaissance (London: Warburg Institute, and Turin: Nino Aragno Editore, 2011), pp. 225-229. For discussion of some other passages in which Renaissance authors express their doubts about the correctness of the ancients see R. Hooykaas, Humanism and the Voyages of Discovery in 16th Century Portuguese Science and Letters (Amsterdam and New York: Noord-Hollandsche U.M., 1979).

${ }^{165}$ See Marica Milanesi, “A Forgotten Ptolemy: Harley Codex 3686 in the British Library,” Imago Mundi 48 (1996), pp. 43-64.

${ }^{166}$ See Falchetta, Fra Mauro's World Map (see note 143), pp. 452-453, *1405; pp. 698-701, *2834; and pp. 710-711, *2892.

${ }^{167}$ For discussion of the Tabulae modernae or Tabulae novae added to manuscripts and editions of Ptolemy see James Richard Akerman, "On the Shoulders of a Titan: Viewing the World of the Past in Atlas Structure,” Ph.D. Dissertation, The Pennsylvania State University, 1991, pp. 228253. On maps of the New World in printed editions of Ptolemy see Oswald A. W. Dilke and Margaret S. Dilke, "The Adjustment of Ptolemaic Atlases to Feature the New World," in Wolfgang Haase and Meyer Reinhold, eds., The Classical Tradition and the Americas, vol. 1.1, European Images of the Americas and the Classical Tradition (Berlin and New York: Walter de Gruyter, 1994), pp. 117-134; and for lists of the tabulae modernae in several printed editions of Ptolemy see Uta Lindgren, "Die Geographie des Claudius Ptolemaeus in München: Beschreibung der gedruckten Exemplare in der Bayerischen Staatsbibliothek,” Archives Internationales d'Histoire des Sciences 35.114-115 (1985), pp. 148-239.
} 
In 1505, Waldseemüller together with Matthias Ringmann and other colleagues began work on a new edition of Ptolemy's Geography, which after several long delays was published in 1513. Two years earlier, Bernardus Sylvanus had published an edition of the Geography in Venice. ${ }^{168}$ In his introduction, Sylvanus says that in studying Ptolemy, ${ }^{169}$

Cum Ptolemaeum inter alios geographiae scriptores diligentissime et situs et distantias locorum scripsisse conspicerem admirabar profecto cur illius tabulae paucis admodum in rebus cum nostri temporis navigationibus consentirent: eoque magis admirabar quod Ptolemaeum quoque navigationibus comprimis innixum ea quae scripserit scripsisse arbitrabar.

Although I used to view Ptolemy as having recorded the sites and distances of places more diligently than other writers of geography, I was none the less puzzled as to why his tables agreed in very few instances with the navigations of our times: and I was all the more puzzled because I used to think that Ptolemy too had recorded what he recorded relying on navigations more than anything else.

Sylvanus revised Ptolemy's maps and data in accordance with recent nautical charts, convincing himself that in doing so he was actually restoring them to what Ptolemy had originally intended. Specifically, he copied the coastlines from nautical charts (where available), but retained the place names and hinterland geographical details of Ptolemy, then extrapolated latitude and longitude values for the new coastlines, and adjusted the data in Ptolemy's text appropriately. ${ }^{170}$ Thus Sylvanus's edition clearly shows that nautical charts were seen as superior to then-available Ptolemaic maps at least in some quarters in the early sixteenth century, and from a comment that Waldseemüller makes in the introduction to the index in his edition of Ptolemy, it seems very likely that he had seen Sylvanus's edition. ${ }^{171}$

On the title page of his 1513 edition of Ptolemy, ${ }^{172}$ Waldseemüller says that it consists of two parts; first the text of the Geography, an index, a brief account of the Greek numbering system, and twenty-seven Ptolemaic maps, and then:

Pars secunda moderniorum lustrationum viginti tabulis veluti supplementum quoddam antiquitatis obsoletae suo loco quae vel abstrusa vel erronea videbantur resolutissime pandit.

The second part, through twenty maps of modern explorations, boldly offers a kind of supplement to obsolete antiquity

[i.e. obsolete ancient authors] wherever it seems to be obscure or erroneous.

The separate one-page introduction to the second part of the work discusses how time changes many things, and how the names of many cities and regions are different than what they had been previously - a passage very similar to part of the introductory paragraph on the Carta marina (compare Legend 9.3) ${ }^{173}$ :

Ptolemaei Geographiam prima parte clausimus operis: ut incorruptior \& selecta stet antiquitas sua. Verum quia temporis lapsus multa quidem labilitate quoque sua indies mutat: plaerisque visus est auctor notabilius a modernioribus deuiasse. Id quod cernere licet in utraque Pannonia, quae nunc Hungaria \& Austria vocatur. Et quae regio dum floruit unica appellatione Sarmatia, siue Sauromatia dicebatur: nunc diuisim Poloniam, Russiam, Prussiam, Moscouiam \& Lituaniam nominamus. Populorum denique usui placuit transmutatio vocabulorum. Quos enim vetustas Eluetios \& Sequanos, nunc vulgo Burgundiones Suitensesque vocamus. Quaedam \& ciuitates primitiuis nominibus orbati sunt. Quis enim iuxta Rhenum Flauium, Canodurum, Augustam rauricum, Elcebum \& Berthomagum urbes a Ptolemaeo comemoratas digito mostrabit?

\footnotetext{
${ }^{168}$ Sylvanus's edition has been published in facsimile as Ptolemy, Geographia: Venice, 1511 (Amsterdam: Theatrum Orbis Terrarum, 1969). For discussion of Sylvanus's work as a cartographer see Robert W. Karrow Jr., Mapmakers of the Sixteenth Century and Their Maps (Chicago: Speculum Orbis Press, 1993), pp. 520-524.

${ }^{169}$ This passage is from the first page of Sylvanus's introduction; R. A. Skelton translates the passage into English in his "Bibliographical Note," in Ptolemy, Geographia: Venice, 1511 (Amsterdam: Theatrum Orbis Terrarum, 1969), pp. v-xi, at vii. But here we borrow the translation from Margaret Small, "Warring Traditions: Ptolemy and Strabo in the Geography of Sebastian Münster," in Zur Shalev and Charles Burnett, eds., Ptolemy's Geography in the Renaissance, pp. 167-185, at 177.

${ }^{170}$ For discussion of Sylvanus's methods for updating Ptolemy's maps and text see Giulia Guglielmi-Zazo, "Bernardo Silvano e la sua edizione della Geografia di Tolomeo," Rivista Geografica Italiana 32 (1925), pp. 37-56 and 207-16; and 33 (1926), pp. 25-52; and R. A. Skelton, "Bibliographical Note," in Ptolemy, Geographia: Venice, 1511 (Amsterdam: Theatrum Orbis Terrarum, 1969), pp. v-xi.

${ }^{171}$ Waldseemüller writes Quod tanta ordinis sui confusione scatet, ut in plerisque locis an modernioribus an Ptolomaeo ipsi conquadret, lector etiam studiosissimus nesciat, that is, "There is so much confusion in the presentation, that in many places even very learned readers cannot tell which data comes from modern authors, and which from Ptolemy himself."

${ }^{172}$ For bibliography on the 1513 edition of Ptolemy's Geography see note 17.

${ }^{173}$ The translation is from Henry N. Stevens, The First Delineation of the New World and the First Use of the Name America on a Printed Map (London: H. Stevens, Son \& Stiles, 1928), p. 40.
} 
We have confined the Geography of Ptolemy to the first part of the work, in order that its antiquity may remain intact and separate. But since the course of time changes many things from day to day as it passes, it has become generally evident that the author deviates notably from those more modern, as may be seen in the two Pannonias, which are now called Hungary and Austria; and the region which was called while it flourished, by the sole appellation of Sarmatia or Sauromatia, we now name in its divisions, Poland, Russia, Prussia, Muscovy and Lithuania. Change in the names of nations has also come into use. For those whom the ancients called Helvetii and Sequani, we now commonly call Burgundians and Swiss. Certain cities, too, have lost their primitive names, for who with his finger will point out on the River Rhine the cities Canodorum, Augusta Rauricum, Elcebus and Berthomagus mentioned by Ptolemy?

He then continues ${ }^{174}$ :

Haec vel his similia non est qui Auctoris imperitiae subscribat. Quin potius hoc Supplemento modernioris lustrationis discat seipsum certius informare. Qua tripartiti orbis explanationem planius ad tempora nostra videbit. Charta autem Marina, quam Hydrographiam vocant, per Admiralem quondam serenissi. Portugaliae regis Ferdinandi, caeteros denique lustratores verissimis peragrationibus lustrata....

These or similar [inaccuracies in place names] let no one attribute to the ignorance of the author [i.e. Ptolemy], but rather from this supplement let him learn to inform himself more accurately about modern explorations, in which he will see an image of the three parts of the world more clearly adapted to our times. Specifically the nautical chart which they call a hydrography, which was surveyed by the very authentic explorations of a former Admiral of Ferdinand, the Most Serene King of Portugal, and of other explorers....

There is a slip of the pen here, as Ferdinand was not king of Portugal, but rather of Aragon, and through his wife, Isabela, of Castile. ${ }^{175}$ The Admiral in question must be Columbus, ${ }^{176}$ but it is misleading to call the map (as a number of scholars have done) "The Admiral's Map," implying a particularly close connection with Columbus. Waldseemüller clearly states that the map is based on the discoveries not only of Columbus but also of other explorers. In any case, we see that by 1513 Waldseemüller had realized that Columbus, rather than Vespucci, was the first to reach the New World.

The new world map in the 1513 Ptolemy (Fig. 1.27) serves as an important indicator of the development of Waldseemüller's thinking about cartography at that time. The title of the map is Orbis Typus Universalis Iuxta Hydrographorum Traditionem, "General Map of the World According to the Tradition of the Hydrographers." By "hydrographers" Waldseemüller means the makers of nautical charts: the map has a system of rhumb lines like a nautical chart, and no Ptolemaic grid of latitude and longitude, though it does indicate the equator and tropics. Thus the cartographer is clearly proclaiming that a world map "more clearly adapted to our times" must be based on nautical charts, and the depiction of southern Asia shows the influence of the Caverio chart, while the shape of Africa is also clearly based on recent Portuguese cartographic data. Moreover, and this is very important, of the twenty modern charts in the 1513 Ptolemy, all but one are made using a nautical chart projection, rather than one of Ptolemy's projections - a strong confirmation of Waldseemüller's recognition of the value of nautical cartography. ${ }^{177}$

At the same time, even while Waldseemüller proclaims that his new world map in the 1513 Ptolemy is based on nautical cartography, certain elements of the map do not derive from that genre: his depiction of Scandinavia and the sweeping rounded coast of eastern Asia clearly derive from one of the world maps by Henricus Martellus (Fig. 1.28). ${ }^{178}$ Waldseemüller had based his 1507 map on a large world map by Martellus similar to that at Yale, so the elements from

\footnotetext{
${ }^{174}$ This passage is translated into English by Stevens, The First Delineation of the New World (see note 173), p. 40, and part is quoted in Robert W. Karrow Jr., "Intellectual Foundations of the Cartographic Revolution,” Ph.D. Dissertation, Loyola University of Chicago, 1999, pp. 184-185; I modify that translation slightly here.

${ }^{175}$ R. A. Skelton suggests the error was caused by words having dropped out of the text: see his "Bibliographical Note" in Ptolemy, Geographia, Strassburg, 1513 (see note 172), p. xvi.

${ }^{176}$ See Samuel McCoskry Stanton, “The Admiral's Map: What Was It? And Who the Admiral?" Isis 22.2 (1935), pp. 511-515.

${ }^{177}$ Some of Waldseemüller's inclination to abandon Ptolemy is visible even in the Ptolemaic part of the 1513 edition of the Geography: in the Ptolemaic world map, Waldseemüller omits the traditional Ptolemaic land bridge along the map's southern edge that (so Ptolemy believed) joined southern Africa and southern Asia, and would render it impossible to sail around Africa to Asia. Even while depicting the world according to Ptolemy, Waldseemüller could not bring himself to depict a landmass he knew did not exist.

${ }^{178}$ This map by Martellus is in Florence, Biblioteca Nazionale Centrale, Landau Finaly, Carte Rosselli, planisfero. It is very similar to the world maps that illustrate manuscripts of Martellus's Insularium illustratum. For discussion of the map see Sebastiano Crinò, "I planisferi de Francesco Rosselli dell'epoca delle grandi scoperte geografiche," La Bibliofilia 41 (1939), pp. 381-405, esp. 393-401; Roberto Almagià, "On the Cartographic Work of Francesco Rosselli," Imago Mundi 8 (1951), pp. 27-34, esp. 3-2; and Tony Campbell, The Earliest Printed Maps, 14721500 (London: British Library, 1987), pp. 70-78, esp. 72-74.
} 


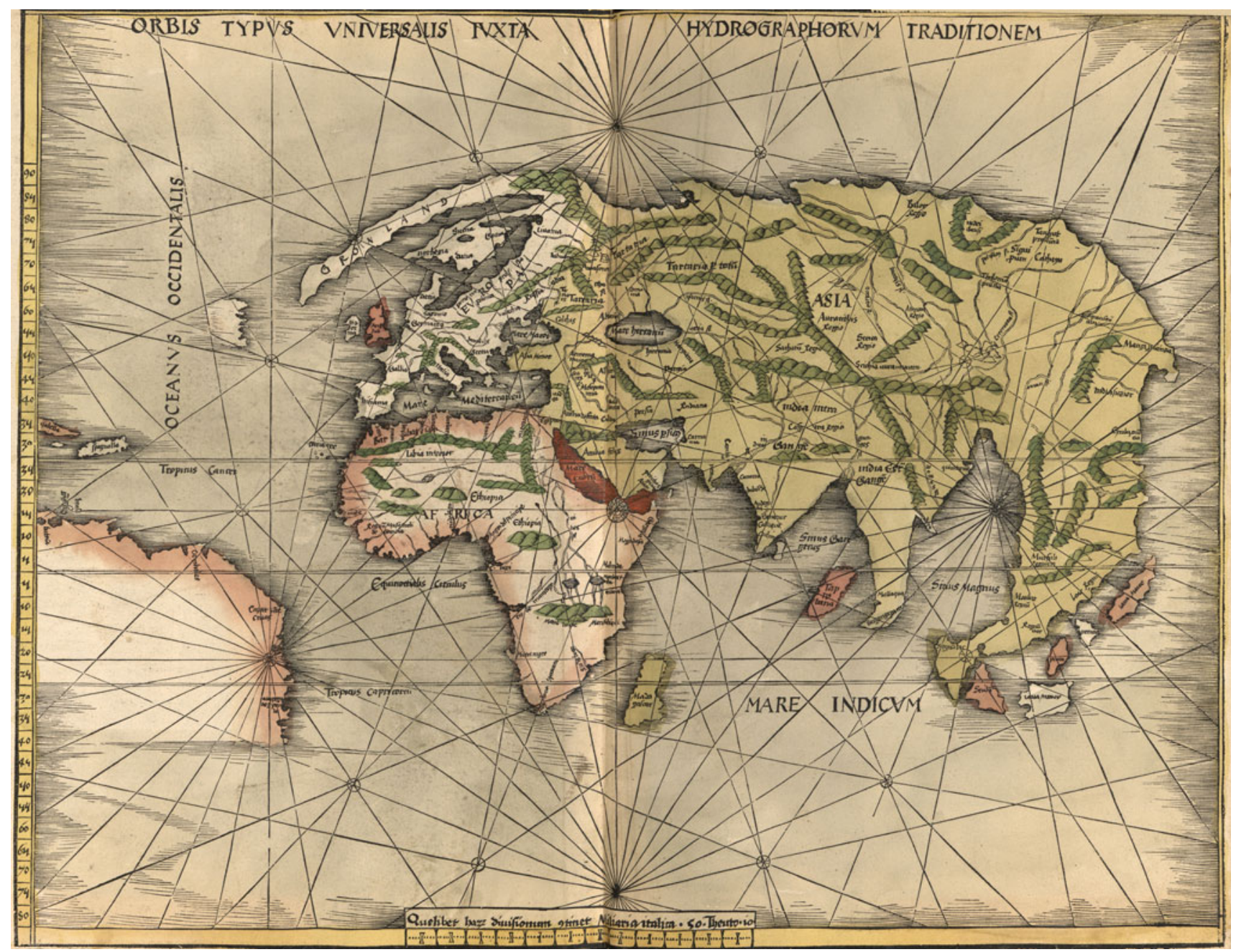

Fig. 1.27 "Modern" world map by Waldseemüller, the so-called "Admiral's Map", in the 1513 edition of Ptolemy's Geography. Library of Congress, Rare Book and Special Collection Division, Rosenwald Collection 624. Courtesy of the Library of Congress

Martellus in this new world map in the 1513 Ptolemy show that in some ways Waldseemüller was still holding onto this older style of cartography.

The 1513 Ptolemy shows Waldseemüller at a point of transition. Certainly he would not have devoted the time and energy to creating a new edition of Ptolemy if he did not believe in the value of Ptolemaic geography and cartography. The elements of Ptolemy and Martellus in his new world map also reflect that belief. But his twenty modern maps in the book, ${ }^{179}$ almost as many as Ptolemy's twenty-seven, and all but one of which are made according to the principles of nautical charts, constitute a cartographic parallel universe to Ptolemy's. Further, his declarations about the value of nautical charts clearly indicate that if one has to choose a cartographic system for a modern world map, it will be that of nautical charts - manifestly anticipating the purer expression of that philosophy in the Carta marina.

\footnotetext{
${ }^{179}$ The large number of modern maps in the 1513 Ptolemy recall the collection of twelve such maps in a manuscript of Ptolemy's Geography made between 1480 and 1496 (Florence, Biblioteca Nazionale Centrale, Magliabechiano XII 16) by a cartographer whose works were clearly well known to Waldseemüller, namely Henricus Martellus. For discussion of this manuscript see Sebastiano Gentile, ed., Firenze e la scoperta dell 'America: umanesimo e geografia nel '400 fiorentino (Florence: L. S. Olschki, 1992), pp. 240-243 with plates 47-48, including a good list of the tabulae modernae and bibliography; and Cavallo, Cristoforo Colombo e l'apertura degli spazi (see note 134), vol. 1, pp. 517-521, with a good color reproduction of the world map on pp. 518-519. The manuscript has been published in facsimile as Ptolomei cosmographia (Florence: Vallecchi, 2004), with studies by Sebastiano Gentile and Angelo Cattaneo. The "Introduzione" by Cattaneo, pp. 23-53, is a valuable description and analysis of the manuscript and its maps.
} 


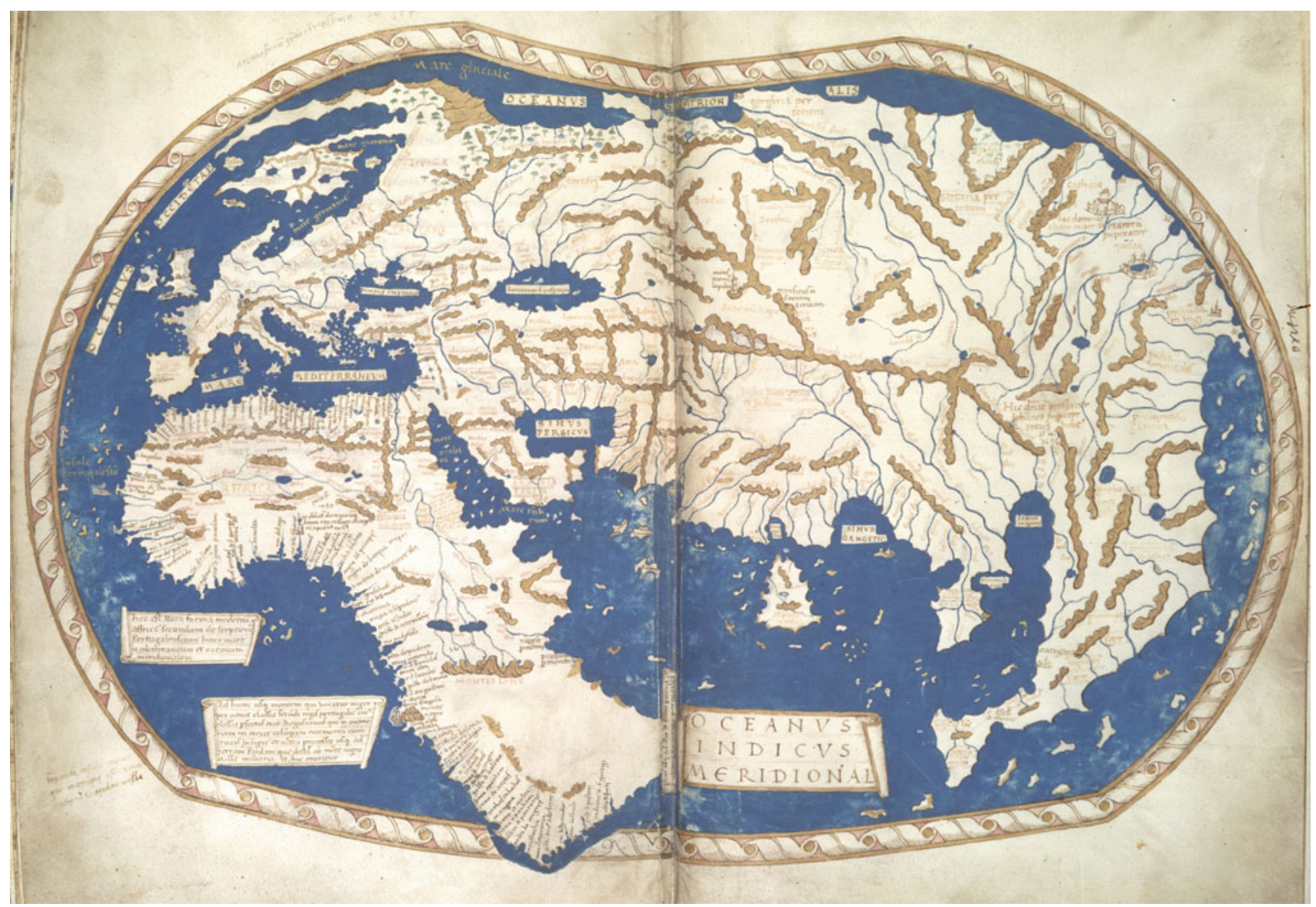

Fig. 1.28 World map by Henricus Martellus in a manuscript of his Insularium illustratum, c. 1490. British Library, Add. MS 15760, ff. 68v-69r. (C) The British Library Board

\subsection{The Cutting of the Woodblocks for the Carta Marina}

Careful examination of the sheets of the Carta marina shows that multiple artisans were involved in cutting the woodblocks, and also a lack of close coordination among those workers. This contrasts with the situation with Waldseemüller's 1507 map, where the signs of different hands and of lack of coordination between those cutting adjacent blocks are more subtle. Illustrations supporting the points made in the following paragraphs can be found in Fig. 1.4, of the whole Carta marina, and in the plates of each sheet of the map below at the beginning of the relevant sections of the transcription.

On the Carta marina there are significant differences of style in the rendering of the wind-heads and associated decorations in the map's margins. For example, the lines representing the wind blown by two of the wind-heads in the margin of sheet 9, in the lower left corner of the map, cross the border into the map proper, but this is not the case on the other sheets. The margins of some of the sheets have stars as part of their decoration $(1,2,4,8$, and 12), while the others do not; the styles of rendering the clouds varies, with those in the border of sheet 9 being particularly puffy; and the styles of drawing the heads themselves are inconsistent, with those in the border of sheet 12 being more stern in appearance, for example.

The style of rendering the oceans also varies from sheet to sheet. On sheet 1 in the upper left corner of the map the texture of the surface of the water is intermittently depicted, and some clouds are shown above the water, but the ocean on the adjacent sheet 2 has neither of these features - the difference is quite dramatic. On sheet 10 the block cutter gives some texture to the surface of the water, and shows a few clouds (differently than in sheet 1), and both sheet 6 above it, and sheet 11 to its right, have notably more plain styles of rendering the ocean.

The vast majority of the cartouches on the map are simple frames; a few have small geometrical decorations at their tops or sides, namely those on sheet 2 by the southern tip of Greenland, on sheet 6 by the Canary Islands, on sheet 7 off the coast from Mogadishu, on sheet 10 off the coast of Brazil, and on sheet 12 the large cartouche east of Java. And two other 
cartouches have very elaborate artistic decoration: the large cartouche on sheet 9 is embellished with vegetal motifs, knots, scrollwork, and two dragons; and the small cartouche at the right edge of sheet 12 with vegetal motifs and knots.

The block cutters also rendered differently the very simple compass roses at the nodes of the rhumb line network. These compass roses consist of two concentric circles and pointers to the north and east. On sheet 10 they are small and there is very little gap between the two circles, while on sheet 6 directly above they are larger and have a larger gap between their circles. These many stylistic differences among the sheets of the Carta marina demonstrate clearly that multiple block cutters were working on the map.

There are additional differneces between the sheets that point not so much to differences of style between the block cutters as to a lack of coordination among them. The most egregious example is found in the scale of latitude at the left-hand edge of the map, which runs down sheet 1 and sheet 5 , but is not continued on sheet 9 . Also on sheet 9 , it is surprising that the decorative cartouche is cut off by the right-hand edge of the sheet - this sheet shows the most differences from its neighbors of any on the map, and is quite problematic. In addition, there are a few cases of rivers and mountain ranges that are discontinuous from one sheet to another, for example the mountains in Africa just north of the equator at the left edge of sheet 7 that do not continue onto sheet 6 . Mention should also be made of the mountain range that extends from sheet 4 in India south onto sheet 8: it consists of sharp peaks north of that point, and rounded peaks south of that point.

What emerges from this examination of the details of the map is the fact that the production of the Carta marina was chaotic, with inadequate coordination among the artisans cutting the blocks for the map. Was the problem that the cutting was done hastily? Or could it have been the opposite, that the production was drawn out due to lack of funds (for example), and that the different blocks were cut at different times, and that was what reduced the consistency among them? In Legend 9.1 Waldseemüller offers thanks to Hugues des Hazards, Bishop of Toul from 1506 to 1517, presumably for his financial contribution to the production of the Carta marina, but this could have been funds that allowed the project to be brought to completion after a period of difficulties. Thus it does not seem possible to know the nature of the difficulties in the production of the Carta marina without additional evidence, but the inconsistencies among the sheets of the map show that it was indeed a challenging process.

\subsection{Evidence for the Diffusion of the Carta Marina}

Hildegard Binder Johnson has argued that the Carta marina was never published or sold, and that the only surviving copy was not part of the map's print run, but rather a special proof printing ${ }^{180}$; to my knowledge, no evidence to the contrary has been presented by other scholars.

The fact that only one exemplar each of Waldseemüller's 1507 and 1516 maps survives has been used to raise questions about the degree to which both maps were diffused. But this fact does not tell at all against the maps' diffusion: wall maps are notorious for their low survival rates, and there are many sixteenth-century printed maps, both wall maps and in smaller formats, that do not survive at all, or survive in only one or two exemplars. Such maps include:

Giovanni Contarini, world map of 1506 (one exemplar) ${ }^{181}$

Francesco Rosselli, printed nautical chart, c. 1508 (two $)^{182}$

Waldseemüller, Carta itineraria Europae of 1511 (zero) ${ }^{183}$

Louis Boulengier, globe gores of c. 1514 (one) $)^{184}$

Dürer and Stabius, globe map of 1515 (none) $)^{185}$

\footnotetext{
${ }^{180}$ For the assertion that the 1516 Carta marina never reached the market see Johnson, Carta marina (see note 21), pp. 57-59. R. A. Skelton in his review of Johnson's book in Geographical Review 55.2 (1965), pp. 307-308, accepts this conclusion.

${ }^{181}$ The unique surviving exemplar of Contarini's map is in London, British Library, Maps C.2.cc.4., and is reproduced in facsimile with commentary in A Map of the World, Designed by Gio. Matteo Contarini, Engraved by Fran. Roselli 1506 (London: Printed by Order of the Trustees, Sold at the British Museum, 1926).

${ }^{182}$ Rosselli's map is in Florence, Biblioteca Nazionale Centrale, Landau Finaly carte Rosselli.

${ }^{183}$ For references on the 1511 printing of Waldseemüller's Carta itineraria Europae see note 14 above.

${ }^{184}$ The unique surviving exemplar of Boulengier's globe gores are in the New York Public Libray, Rare Book Division, *KB 1517 (Waldseemüller, M. Cosmographiae Introdvctio/Cvm Qvibvsdam/Geometriae).

${ }^{185}$ Although no contemprary printings of the Dürer-Stabius globe-map survive, the woodblocks are in the Albertina in Vienna, with reference numbers HO2006/676-678; for discussion of the map see Günther Hamann, "Die Stabius-Dürer Karte von 1515," Kartographische Nachrichten 21.6 (1971), pp. 212-223.
} 
Waldseemüller, Carta itineraria Europae of 1520 (one) ${ }^{186}$

Giovanni Vespucci, world map of 1524 (two) ${ }^{187}$

Lorenz Fries, Carta marina of 1525 (zero) ${ }^{188}$

Lorenz Fries, Carta marina of 1530 (one) ${ }^{189}$

Lorenz Fries, Carta marina of 1531 (one) ${ }^{190}$

Sebastian Cabot, world map of 1544 (two) ${ }^{191}$

Giacomo Gastaldi, Univesale of 1546 (two) ${ }^{192}$

Caspar Vopel, world map of 1558 (one) ${ }^{193}$

Giacomo Gastaldi, world map of c. 1561 (one) $)^{194}$

Diego Gutiérrez, map of the New World, 1562 (two) ${ }^{195}$

Gerard Mercator, world map of 1569 (three) ${ }^{196}$

Caspar Vopel, world map of 1570 (one) ${ }^{197}$

Georg Braun, world map of 1574 (one) ${ }^{198}$

Petrus Plancius, world map, Amsterdam/Antwerp, 1592 (one) ${ }^{199}$

Jodocus Hondius, wall map of 1595-96 (one) 200 $^{20}$

This list might very easily be expanded, so it is not at all unusual that Waldseemüller's two wall maps survive in only one exemplar each, and the fact that more exemplars do not survive cannot be adduced as evidence of a small print run or low diffusion.

The main difficulty in finding good evidence for the dissemination of Waldseemüller's Carta marina is distinguishing between its influence, and the influence of its re-edition by Lorenz Fries. ${ }^{201}$ In 1525, Fries and the publisher Johann Grüninger produced a new version of the map, on a somewhat reduced scale $(1876 \times 1031 \mathrm{~mm}$, or $74 \times 40.6$ inches, versus $2330 \times 1280 \mathrm{~mm}$, or $91.7 \times 50.4$ inches for Waldseemüller's map), with most of the legends translated into German, and accompanied by a booklet with more detailed descriptions of various parts of the world than there was room for on the map itself. ${ }^{202}$ The booklet that Fries wrote is titled Uslegung der mercarthen oder Charta Marina (Explanation of the

\footnotetext{
${ }^{186}$ For references on the 1520 printing of Waldseemüller's Carta itineraria Europae see note 14 above.

${ }^{187}$ The two exemplars of Vespucci's map are at Harvard, Houghton Library, shelfmark p 51-2573; and Wolfenbüttel, Herzog August Bibliothek, shelfmark 15 Astron. $2^{\circ}$. For discussion of the discovery of the Wolfenbüttel exemplar see Christian Heitzmann, "Wem gehören die Molukken? Eine unbekannte Weltkarte aus der Frühzeit der Entdeckungen," Zeitschrift für Ideengeschichte 1.2 (2007), 101-110.

${ }^{188}$ On Fries's work as a cartographer see Robert W. Karrow, Jr., Mapmakers of the Sixteenth Century and Their Maps: Bio-Bibliographies of the Cartographers of Abraham Ortelius, 1570 (Chicago: Published for The Newberry Library by Speculum Orbis Press, 1993), pp. 191-204.

${ }^{189}$ Fries's 1530 Carta marina is in Munich, Bayerische Staatsbibliothek (Mapp. I, 9 m-1). Digital images of the map's sheets are available at http:// daten.digitale-sammlungen.de/bsb00012490/image_1.

${ }^{190}$ Fries's 1531 Carta marina is in Schaffhausen, Switzerland, Museum zu Allerheiligen (Inv. 6102).

${ }^{191}$ The two exemplars of Sebastian Cabot's world map are in Paris, BnF, Rés. Ge AA 582; and Klassik Stiftung Weimar, Kt 020-31 S.

${ }^{192}$ Gastaldi's Universale is at Harvard, Houghton Library, pf 51-2492; and London, British Library, Maps K.Top.4.6.

${ }^{193}$ Vopel's 1558 map is at Harvard, Houghton Library, p 51-2577.

${ }^{194}$ The unique surviving exemplar of Gastaldi's world map of c. 1561 is in London, British Library, Maps C.18.n.1.

${ }^{195}$ Diego Gutiérrez's map is in Washington, Library of Congress, Geography and Map Division, G3290 1562 .G7 Vault Oversize; and London, British Library, Maps * 69810.(18.).

${ }^{196}$ The three surviving exemplars of Mercator's 1569 map are in Paris, BnF, Rés Ge. A 1064; Basel, Universitätsbibliothek, Kartenslg AA 3-5; and Rotterdam, Maritiem Museum "Prins Hendrik," Atlas51.

${ }^{197}$ Vopel's world map of 1570 is in Wolfenbüttel, Herzog-August-Bibliothek, K 3,5.

${ }^{198}$ Braun's world map of 1574 is in Wolfenbüttel, Herzog-August-Bibliothek, K 2,6.

${ }^{199}$ Plancius's world map of 1592 is in Valencia, Colegio del Corpus Christi.

${ }^{200}$ Hondius's world map of c. 1595-96 is in Dresden, Sächsisches Hauptstaatsarchiv, 12884.

${ }^{201}$ For biographical information on Fries see Charles Schmidt, "Laurent Fries de Colmar, médecin, astrologue, géographe à Strassbourg et à Metz," Annales de l'Est 4 (1890), pp. 523-575; and Peter Weidisch, "Lorenz Fries - eine biographische Skizze," in Ulrich Wagner, ed., Lorenz Fries (1489-1550), fürstbischöflicher Rat und Sekretär: Studien zu einem fränkischen Geschichtsschreiber (Würzburg: F. Schöningh, 1989), pp. $23-43$. On his writings see Josef Benzing, "Bibliographie der Schriften des Colmarer Artztes Lorenz Fries," Philobiblon 6 (1962), pp. 121-140.

${ }^{202}$ For a good discussion of this publishing project see Johnson, Carta marina (see note 21); Johnson compares many details of Waldseemüller's and Fries's maps on pp. 51-71. Also see Meret Petrzilka, Die Karten des Laurent Fries von 1530 und 1531 und ihre Vorlage (Zurich: Neuen Zürcher Zeitung, 1970). On Fries's work as a cartographer see Robert W. Karrow, Jr., Mapmakers of the Sixteenth Century and Their Maps: BioBibliographies of the Cartographers of Abraham Ortelius, 1570 (Chicago: Published for The Newberry Library by Speculum Orbis Press, 1993), pp. 191-204.
} 
Sea Chart or Carta marina), and was published by Grüninger in Strasbourg in $1525 .{ }^{203}$ No copy of the 1525 edition of Fries's Carta marina is extant, but single copies of two later editions do survive: one of the 1530 edition in Munich in the Bayerische Staatsbibliothek (Mapp. I,9m-1), ${ }^{204}$ and one of the 1531 edition in Schaffhausen, Switzerland, in the Museum zu Allerheiligen (Inv. 6102), on which the legends are in Latin. ${ }^{205}$

While it may well be true that the copy of Waldseemüller's Carta marina now in the Library of Congress was specially printed, and while the existence of Fries's re-edition makes it challenging to demonstrate the diffusion of Waldseemüller's map rather than of Fries's, there is in fact good evidence that the 1516 map was published and disseminated. ${ }^{206}$ The Huntington Library in San Marino, California, has a manuscript atlas of nautical charts known as the Vallard Atlas, made in the Dieppe region of France in approximately $1547,{ }^{207}$ a product of the so-called Dieppe School of cartography. ${ }^{208}$ A study of the images in this atlas makes it clear that the cartographer had both Waldseemüller's Carta marina and the later edition by Fries in his workshop. The image in the Vallard Atlas of the King of France riding a sea monster south of Africa (Fig. 1.29) is clearly copied from the image on Fries's map (Fig. 1.30), and not from Waldseemüller's (Fig. 1.7). But there are also images that prove that the creator of the atlas had a copy of Waldseemüller's Carta marina. The image of Mecca in the atlas (Fig. 1.31) is strikingly similar to that on Waldseemüller's map (Fig. 1.17), and it is essentially impossible that the cartographer would have painted an image of Mecca so much like Waldseemüller's if he had been working from the simpler image on Fries's map (Fig. 1.32). As shown above, Waldseemüller copied his image of Mecca from the image of Medina in the 1515 illustrated edition of Varthema. Although a detailed image of the city very similar to Waldseemüller's was thus in theory available to the maker of the Vallard Atlas independently of Waldseemüller's map, it is all but inconceivable that the cartographer of the atlas would have consulted Fries's Carta marina and then the 1515 edition of Varthema, and yet not have followed the 1515 book in using the image for Medina, rather than Mecca. So the image of Mecca in the Vallard Atlas is indeed good evidence of the diffusion and influence of Waldseemüller's Carta marina.

There is also strong evidence that the cartographer of the Vallard Atlas used Waldseemüller's Carta marina in his depiction of the Indian Ocean. Specifically, on the third map in the atlas there is a scene of cannibal butchery on lille de geans or the Island of Giants ${ }^{209}$ : a man who looks European holds a large cleaver and is chopping up a human body that is laid out on a butcher's table, with a small conduit to drain the blood into a bucket below (Fig. 1.33). This scene is not similar to the cannibalistic scene on the island of Java on Fries's Carta marina: that scene is much more complex, as Fries has added a woman and a baby, the woman holding a plate for the meat; the stance of the man with the cleaver is different, the body's head is on the ground, the bucket for the blood is off to the side rather than under the table, and there is no sign of the conduit (Fig. 1.34). But the scene in the Vallard Atlas is very similar to Waldseemüller's on Java: the stance and arm positions of the man with the cleaver are the same, and both tables have the conduit and the bucket for blood

\footnotetext{
${ }^{203}$ Johnson gives a good account of the Uslegung in Carta marina (see note 21), pp. 85-116. The full text of the Uslegung is translated into modern German by Petrzilka, Die Karten des Laurent Fries (see note 202), pp. 115-162.

${ }^{204} \mathrm{~A}$ facsimile of the 1530 copy was published in Munich by the bookseller Ludwig Rosenthal c. 1926; digital images of the sheets of the map at the BSB are available at http://daten.digitale-sammlungen.de/bsb00012490/image_1.

${ }^{205}$ The Schaffhausen copy of Fries's Carta marina is hand-colored. For discussion of the map see Henry J. Bruman, "The Schaffhausen Carta Marina of 1531," Imago Mundi 41 (1989), pp. 124-132. Some fragments of what seem to be proof sheets of a Latin edition of Fries's map also survive: see Leo Bagrow, "Fragments of the 'Carta Marina' by Laurentius Fries, 1524," Imago Mundi 14 (1959), pp. $110-112$.

${ }^{206}$ Fischer and von Wieser indicate that Mercator borrowed from Waldseemüller's Carta marina in creating his famous 1569 world map, particularly in his legends in India and the topography and hydrography of southern Africa: see Joseph Fischer and Franz Ritter von Wieser, Die älteste Karte mit dem Namen Amerika (see note 9), p. 40. Johnson is skeptical of Fischer and von Wieser's claim in her Carta marina (see note $21)$, p. 58, and the notes on p. 136. My own study of the matter has revealed only one legend on Mercator's 1569 map that is similar to any on Waldseemüller's Carta marina, and that is the description of the opossum-information that Mercator could have obtained from another source.

${ }^{207}$ The Vallard Atlas is in San Marino, California, Huntington Library HM 29. It has been reproduced in facsimile as Atlas d'ancienne cartes: Atlas Vallard (Barcelona: M. Moleiro Editor, 2008-2010), with a volume of commentary by Luís Filipe F. R. Thomaz, Dennis Reinhartz, and Carlos Miranda García-Tejedor. High-resolution images of the maps are available via the Digital Scriptorium at http://www.digital-scriptorium.org/.

${ }^{208}$ On the "Dieppe School" see Henry Harrisse, "La cartographie Américano-Dieppoise," in his Découverte et évolution cartographique de TerreNeuve et des pays circonvoisins, 1497-1501-1769 (London and Paris, 1900; Amsterdam: N. Israel, 1968), Part 2, Chaps. 2-11; and Gayle K. Brunelle, "Dieppe School," in David Buisseret, ed., The Oxford Companion to World Exploration (New York: Oxford University Press, 2007), pp. 237-238. There is a list of all of the maps produced by the Dieppe cartographers in the Appendix to Sarah Toulouse, "Marine Cartography and Navigation in Renaissance France," in David Woodward, ed., The History of Cartography, Volume 3, Cartography in the European Renaissance, Part 2 (Chicago: The University of Chicago Press, 2007), pp. 1550-1568.

${ }^{209}$ On the Island of Giants in the Vallard Atlas and in Jean Rotz's Boke of Idrography of 1542 see W. A. R. Richardson, "Enigmatic Indian Ocean Coastlines on Early Maps and Charts," The Globe: Journal of the Australian Map Circle 46 (1998), pp. 21-41, esp. 34.
} 
Fig. 1.29 Detail of the King of France riding a sea monster south of Africa from the Vallard Atlas. San Marino, California,

Huntington Library, MS HM 29, f. 5. Courtesy of the Huntington Library

Fig. 1.30 King Manuel of Portugal riding a sea monster south of Africa on Laurent Fries's Carta marina of 1530.

Bayerische Staatsbibliothek, Mapp. I,9m-1. Courtesy of the Bayerische Staatsbibliothek
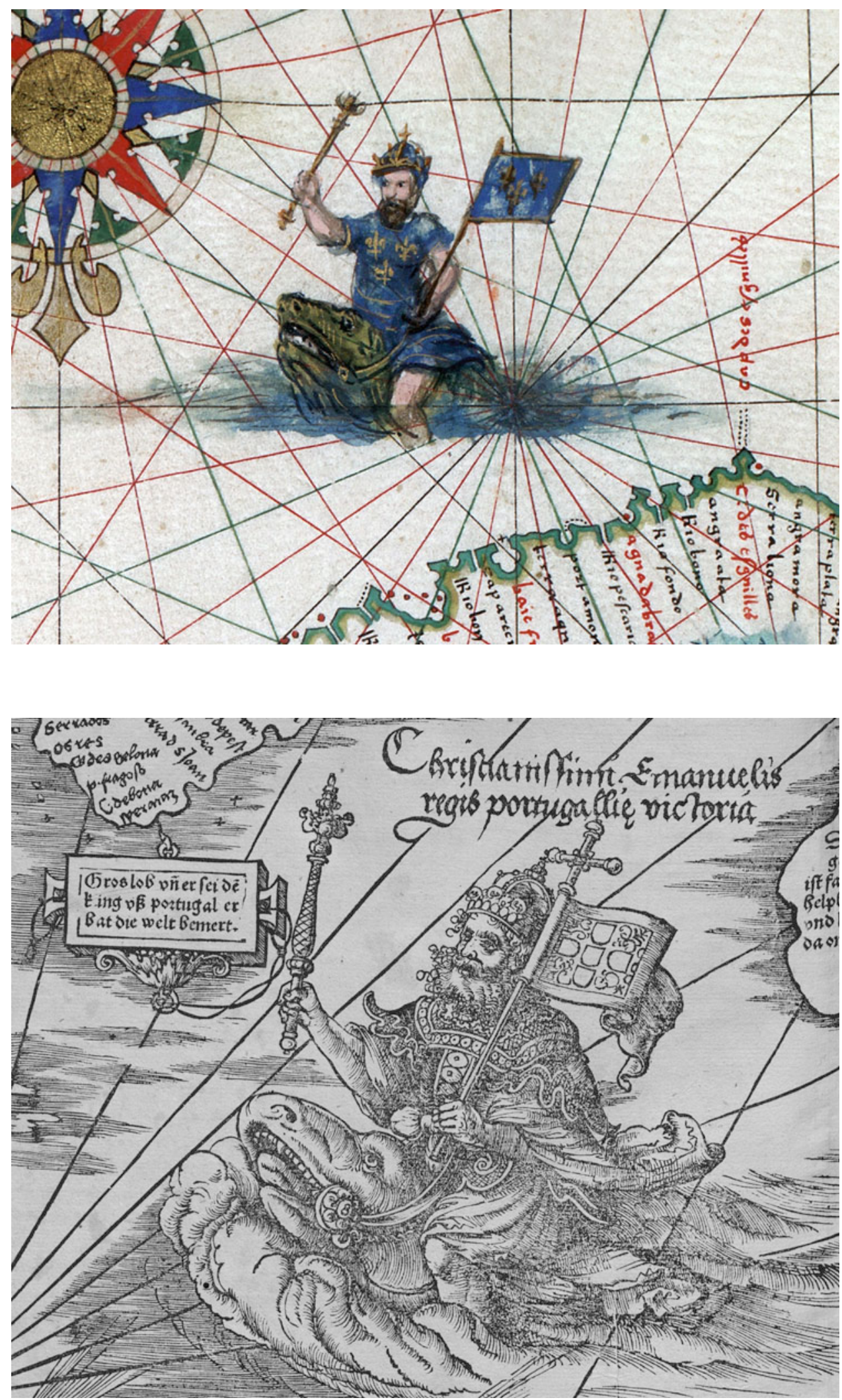


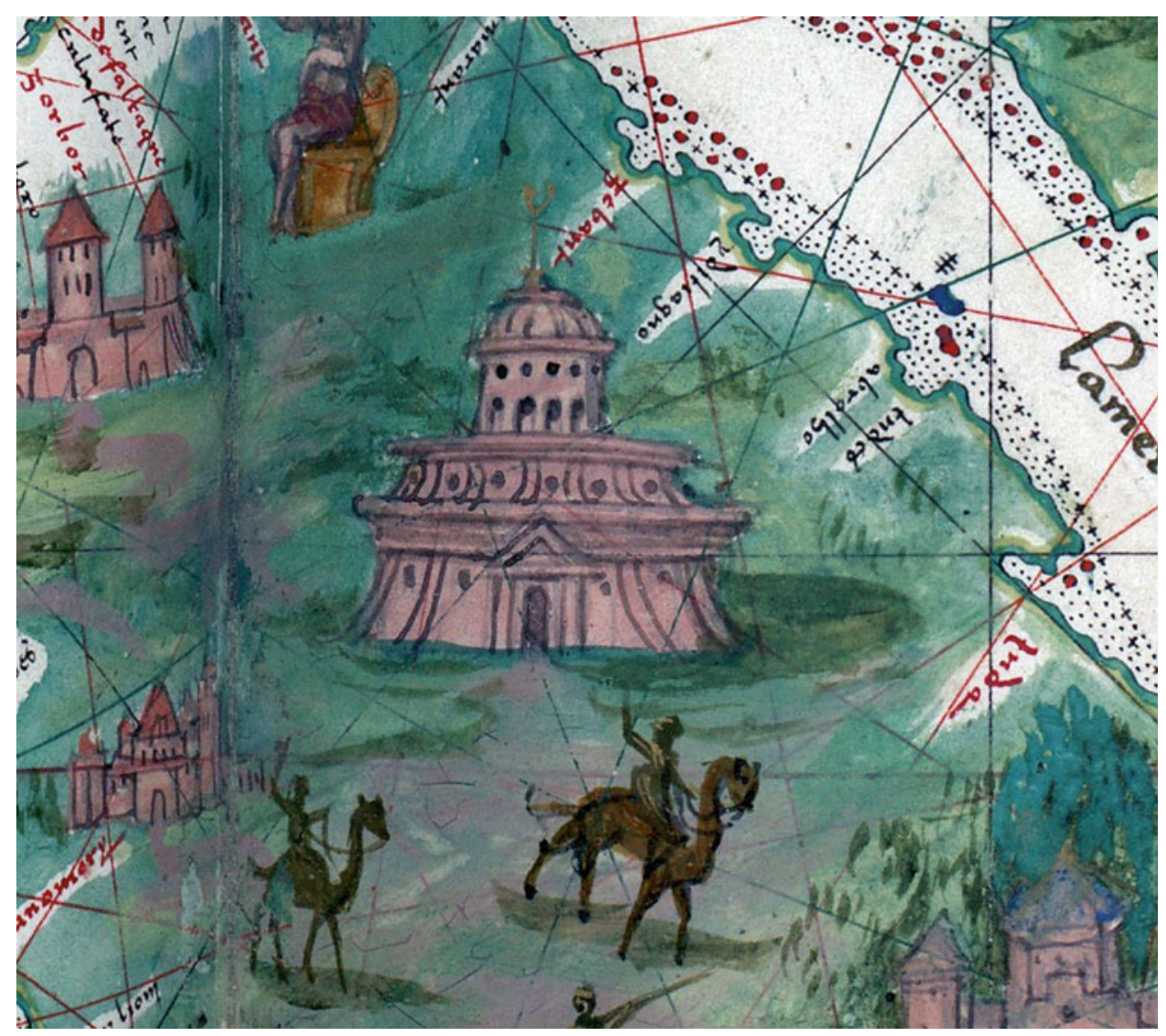

Fig. 1.31 Detail of Mecca from the Vallard Atlas. San Marino, California, Huntington Library, MS HM 29, f. 4. Courtesy of the Huntington Library

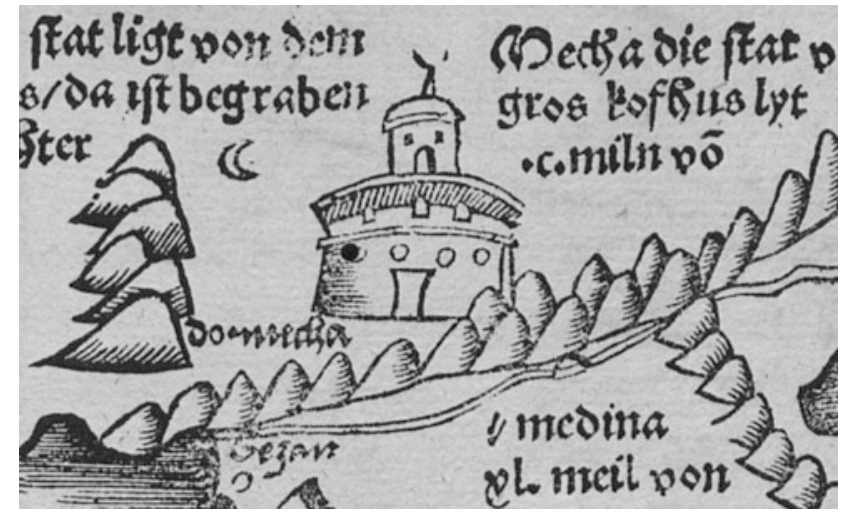

Fig. 1.32 Mecca on Laurent Fries's Carta marina of 1530. Bayerische Staatsbibliothek, Mapp. I,9m-1. Courtesy of the Bayerische Staatsbibliothek 


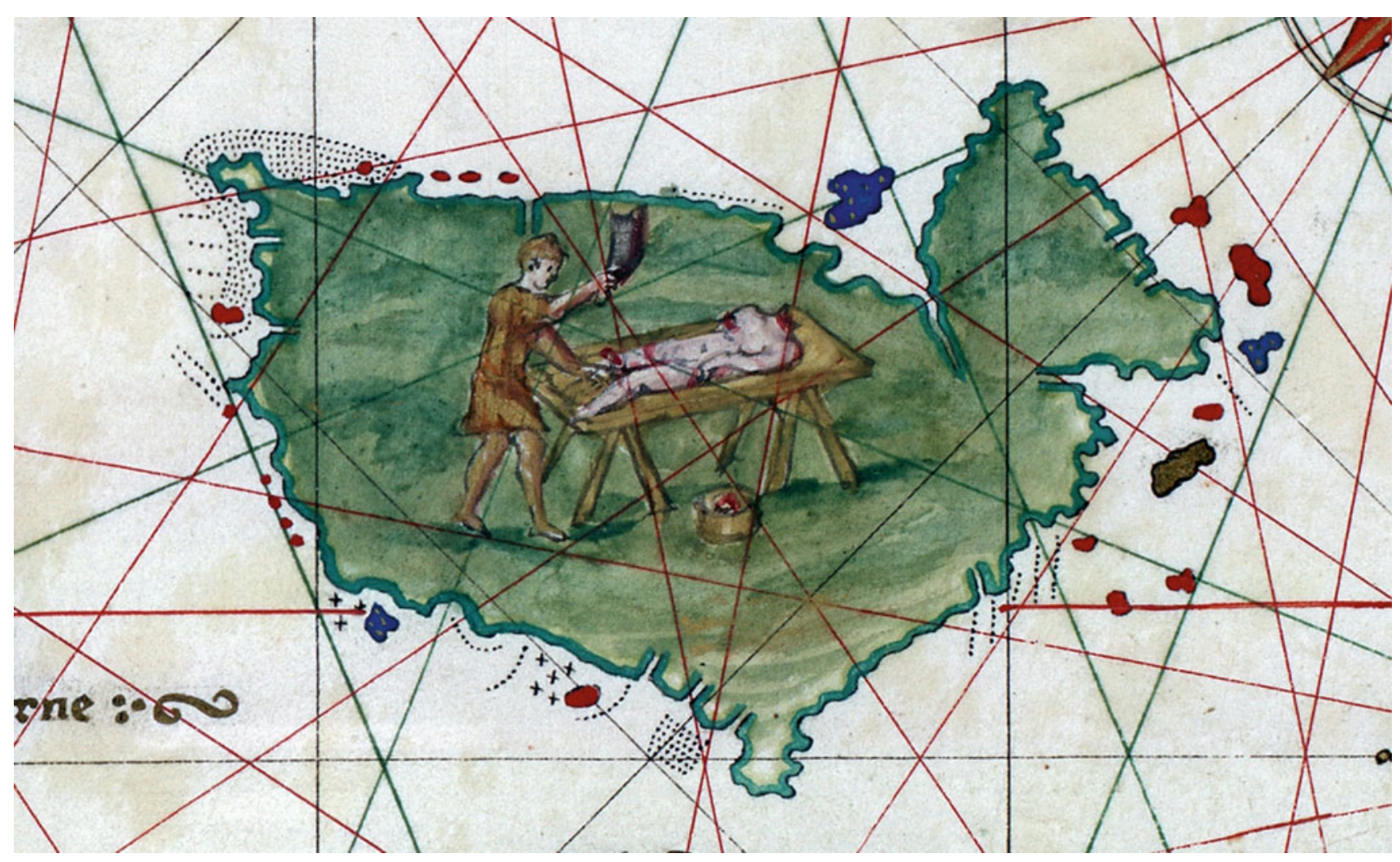

Fig. 1.33 Cannibal butchery on lille de geans or the Island of Giants from the Vallard Atlas. San Marino, California, Huntington Library, MS HM 29, f. 3. Courtesy of the Huntington Library

beneath them (Fig. 1.35). ${ }^{210}$ Again, it is inconceivable that the cartographer of the Vallard Atlas could have arrived at an image so similar to Waldseemüller's if he were only working from Fries's map.

There is additional corroboratory evidence in Northern Europe that the maker of the Vallard Atlas used of Waldseemüller's Carta marina as a source. As we saw earlier, Waldseemüller portrays the walrus as a creature that looks very much like an elephant (see Fig. 1.10). Lorenz Fries copies this image in the 1522 edition of Ptolemy in the Tabula moderna Gronlandie et Rusie and also in his version of the Carta marina $(1530,1531)$, and there is a similar image in the Vallard Atlas in the map of Western Europe and the Mediterranean (ff. $7 \mathrm{v}-8 \mathrm{r}$ ). But again, only Waldseemüller's map can have been the source. The walrus in the 1522 Ptolemy has a long elephantine trunk, which the image on the Vallard Atlas does not have; the image on Fries's Carta marina is much more similar to that on the Vallard Atlas, but it shows the elephant's far ear sticking up above the elephant's head to some extent, which is the case on Waldseemüller's map, but not on Fries's.

There is also good evidence that Waldseemüller's Carta marina was available to the sixteenth-century Norman cartographer Pierre Desceliers. Elsewhere I have argued that Desceliers copied his image of the former Hindu practice of suttee or sati (in which a widow threw herself on her husband's funeral pyre) on his 1546 world map from Waldseemüller's Carta marina, rather than from the Tabula moderna Indiae in Fries' 1522 Ptolemy or from Fries' edition of the Carta marina. ${ }^{211}$ It also seems very likely that Desceliers copied his image of Jean-François de La Rocque de Roberval's 1542 settlement in

\footnotetext{
${ }^{210}$ There is no similar scene of cannibalism in the Indian Ocean in the 1513 edition of Ptolemy's Geography that might have influenced the cartographer of the Vallard Atlas, and the scene of cannibalistic butchery in the Tabula moder[na] Indie Orientalis in the 1522 (Strasbourg), 1525 (Strasbourg), 1535 (Lyon), and 1541 (Vienna) editions of Ptolemy's Geography, whose maps were made by Fries, is quite different, and certainly did not influence the cartographer of the Vallard Atlas. For descriptions of these editions of Ptolemy see Wilberforce Eames, A List of Editions of Ptolemy's Geography 1475-1730 (New York, 1886) (reprinted from Joseph Sabin's Bibliotheca Americana), pp. 15-17, 17-18, 18-19, and 2021; and Carlos Sanz, La Geographia de Ptolomeo, ampliada con los primeros mapas impresos de América, desde 1507 (Madrid: Librería General V. Suárez, 1959), pp. 150-155, 156-164, 169-178, and 187-189.

${ }^{211}$ Desceliers' 1546 map is in Manchester, John Rylands Library, French MS $1^{*}$; for discussion of the image of sati see Chet Van Duzer, The World for a King: Pierre Desceliers' Map of 1550 (London: British Library, 2015), pp. 43 and 46.
} 


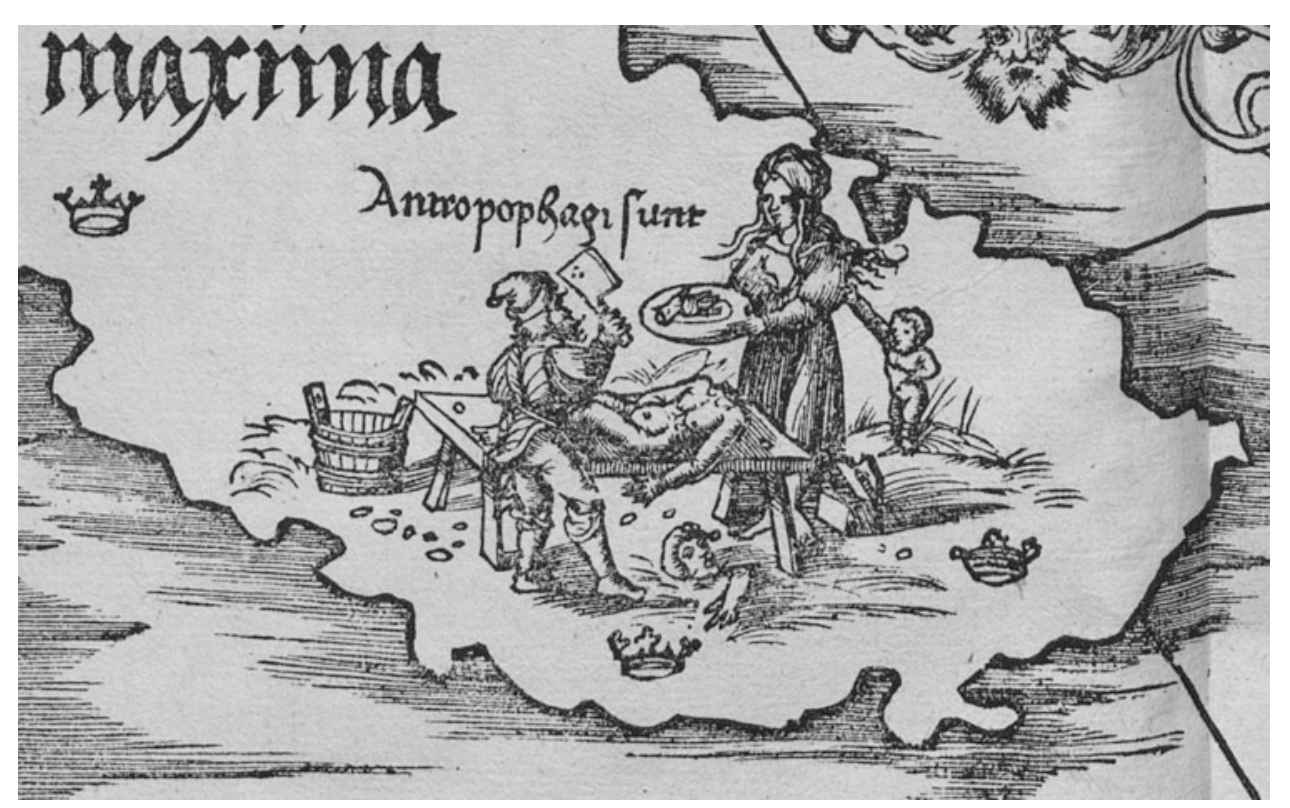

Fig. 1.34 The cannibalistic scene on the island of Java on Laurent Fries's Carta marina of 1530. Bayerische Staatsbibliothek, Mapp. I,9m-1. Courtesy of the Bayerische Staatsbibliothek

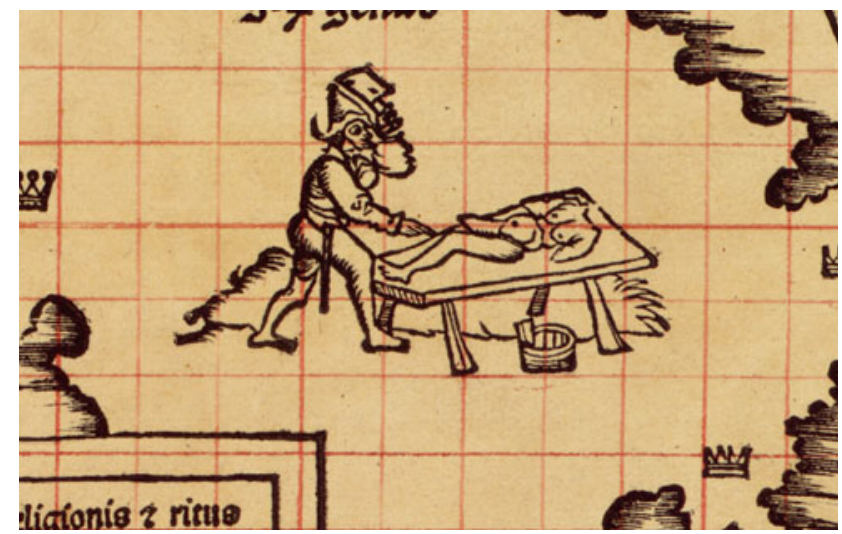

Fig. 1.35 The cannibalistic scene on the island of Java on Waldseemüller's Carta marina (sheet 12). Courtesy of the Library of Congress

Canada from Waldseemüller's image of Mecca, ${ }^{212}$ discussed just above (see Fig. 1.17), but it is at least possible that Desceliers copied his image from that of Mecca in the Vallard Atlas (see Fig. 1.31), which was made three years before his 1550 map.

There is one other very clear piece of evidence confirming that Waldseemüller's Carta marina was disseminated: Abraham Ortelius cites the map as a source in his Theatrum orbis terrarum of 1570. In his Catalogus auctorum tabularum geographicarum (Catalog of mapmakers), on p. Cii, Ortelius writes:

Martinus Ilacomilus Friburgensis, Europam; eam alicubi in Germania impressam habemus.

Martinus Waldseemuller, Universalem navigatoriam (quam Marinam vulgo appellant) in Germania editam. Puto hunc eundem esse cum Ilacomilo praedicto.

Martin Ilacomylus of Freigburg, a map of Europe; we have a copy printed somewhere in Germany. ${ }^{213}$

\footnotetext{
${ }^{212}$ Van Duzer, The World for a King (see note 211), pp. 10-11.

${ }^{213}$ The reference is to Waldseemüller's Carta itineraria Europae, first published in 1511; for bibliography on the map see note 14 above.
} 
Martin Waldseemüller, Universal nautical chart (which is commonly called a marine chart) published in Germany.

I think that this cartographer is the same as the Ilacomylus just mentioned.

This passage is the clearest possible corroboration that the Carta marina did in fact circulate and influence other cartographers, and not just in the Dieppe region.

However, some other claims that Waldseemüller's Carta marina influenced later globes and maps, and thus implicitly must have been well diffused, cannot be accepted as proven, largely because of the difficulty presented in distinguishing between the influence of Waldseemüller's map and Fries's. It has been asserted that Gerard Mercator used Waldseemüller's Carta marina as a source in his depiction of southern Africa on his terrestrial globe of $1541,{ }^{214}$ but without any attempt to determine whether the influence was from Waldseemüller's Carta marina or from Fries's. ${ }^{215}$ In fact the place names in southern Africa are very similar on Waldseemüller's map and Fries's, ${ }^{216}$ so the similarities between Mercator's globe and Waldseemüller's map cannot be taken as providing additional evidence that the 1516 map was disseminated.

Fischer and von Wieser, in their introduction to their facsimile edition of Waldseemüller's 1507 and 1516 maps, indicate that Gerard Mercator borrowed from Waldseemüller's Carta marina in creating his famous 1569 world map, ${ }^{217}$ particularly in his legends in India and the topography and hydrography of southern Africa. ${ }^{218}$ But they do not provide details, and in fact after examining the legends on the 1516 and 1569 maps, ${ }^{219}$ I find a close correspondence in only one place, in the legends describing the opossum in South America - and Mercator could have borrowed that legend from the 1531 (Latin) edition of Fries's Carta marina, where it is the same as on Waldseemüller's Carta marina. With regard to southern Africa, as just mentioned, the place names in this region are very similar on Waldseemüller's map and Fries's, so the very similar place names on Mercator's 1569 map and Waldseemüller's Carta marina do not establish that Waldseemüller's map reached Mercator. $^{220}$

Another aspect of the diffusion of Waldseemüller's Carta marina is its copying by Lorenz Fries in his editions of 1525, 1530, and 1531, which have been mentioned several times now. It is unlikely that Fries made use of Johann Schöner's exemplar of the map - the only one that now surives - as the model for his maps, so his editions suggest the existence of at least one other exemplar of Waldseemüller's Carta marina. As Fries's maps are smaller than Waldseemüller's, they contain fewer legends and illustrations; they are also of a substantially lower artistic quality than Waldseemüller's map, ${ }^{221}$ and in fact introduce a number of errors. But as the historian Henry Bruman has noted, the Fries-Grüninger Carta marina had a rather different aim than Waldseemüller's map. Waldseemüller aimed to bring the latest geographical scholarship to a broad audience, while the Fries-Grüninger map was "an object of popularization and commerce, merchandised to a wide public," designed "to disseminate reasonably recent, reasonably accurate information about different parts of the world in a picturesque, decorative way." 222 On the 1530 edition of the map, and presumably in the lost 1525 edition as well, most of the legends are translated into German - an effort at the democratization of cartographic knowledge that is a logical step forward from Waldseemüller's own Carta marina, itself a democratization of an expensive manuscript nautical chart. But in the 1531

\footnotetext{
${ }^{214}$ On Mercator's terrestrial globe see Edward L. Stevenson, Terrestrial and Celestial Globes (New Haven, CT: Yale University Press, 1921), vol. 1, pp. 124-135; and Elly Dekker and Peter van der Krogt, "Les Globes," in Marcel Watelet, ed., Gérard Mercator cosmographe: le temps et l'espace (Anvers: Fonds Mercator Paribas, 1994), pp. 243-267, esp. 246-258.

${ }^{215}$ See Josef Fischer, "Die Hauptquelle für die Darstellung Afrikas auf dem Globus Mercators von 1541," Mitteilungen der Geographischen Gesellschaft Wien 87.4-6 (1944), pp. 65-69; and W. G. L. Randles, "South East Africa and the Empire of Monomotapa as Shown on Selected Printed Maps of the 16th Century," Studia 2 (1958), pp. 103-163, esp. 150.

${ }^{216}$ See Petrzilka, Die Karten des Laurent Fries (see note 202), pp. 54-55.

${ }^{217}$ For the three surviving exemplars of Mercator's 1569 map see note 196. The third of these is hand-colored and has been reproduced in facsimile as Gerard Mercator's Map of the World (1569) in the Form of an Atlas in the Maritiem Museum 'Prins Hendrik' at Rotterdam (Rotterdam, 1961); and more recently as Atlas van der Wereld: De wereldkaart va Gerard Mercator uit 1569 (Zutphen: Walberg Pers, 2011). There is a good, easily accessible reproduction of the whole map in Kenneth Nebenzahl, Atlas of Columbus and the Great Discoveries (Chicago: Rand McNally, 1990), pp. 128-129.

${ }^{218}$ See Joseph Fischer and Franz Ritter von Wieser, Die älteste Karte mit dem Namen Amerika (see note 9), p. 40. Johnson is also skeptical of Fischer and von Wieser's claim: see her Carta marina (see note 21), p. 58, and the notes on p. 136.

${ }^{219}$ The legends on Mercator's map are transcribed and translated into English in Gerard Mercator, "Text and Translation of the Legends of the Original Chart of the World by Gerhard Mercator, Issued in 1569," Hydrographic Review 9.2 (1932), pp. 7-45.

${ }^{220}$ Incidentally there is good evidence that Waldseemüller's edition of Ptolemy, either the 1513 or the 1520 reprint, reached Mercator: in Mercator's edition of Ptolemy, Tabulae Geographicae (Cologne: Typis Godefridi Kempensis, 1578), there is a ship in the Mediterranean on the map of the Holy Land positioned very much as the ship on the corresponding map in Waldseemüller's edition, and there is no ship on this map in any other edition of Ptolemy before Mercator's.

${ }^{221}$ Johnson, Carta marina (see note 21), p. 66, claims that "Fries's world map is altogether artistically superior [to Waldseemüller's]," but most of Fries's images on his map are plainly inferior to Waldseemüller's.

${ }^{222}$ Henry J. Bruman, “The Schaffhausen Carta Marina of 1531,” Imago Mundi 41 (1989), pp. 124-132, p. 130.
} 
edition, the legends are in Latin again, so either the edition in German was not well received, or the publishers wanted to sell a new version of the map to scholars.

Waldseemüller's Carta marina also influenced another early sixteenth-century cartographer, a topic that has been little discussed by map historians, and this influence explains some features of the surviving copy of the Carta marina. As mentioned above, it was Johann Schöner who preserved the only surviving copies of Waldseemüller's 1507 and 1516 maps. Schöner's printed globe of 1515 was heavily influenced by Waldseemüller's $1507 \mathrm{map}^{223}$ and his magnificent but largely unstudied manuscript globe of $1520^{224}$ borrows a number of legends from the Carta marina. ${ }^{225}$

The copy of the Carta marina that Schöner preserved has a number of corrections made by hand, in accordance with the list of corrections that was printed on the lower of two escutcheons in the southwest corner of the map, but is now covered by a small piece of paper (Legend 9.2). ${ }^{226}$ Thus Schöner seems to have taken care that the map was as correct as possible. The grid of red parallels and meridians drawn on much of the map bespeaks careful study and analysis of the map's geography, no doubt by Schöner himself. ${ }^{227}$ Moreover, stored in the Schöner Sammelband together with the twelve printed sheets of the Carta marina was a careful manuscript copy that Schöner made of sheet 6 of the map (here labeled sheet 6A), which covers western Africa. The existence of this manuscript copy has not been previously explained, but we can be quite certain that it was made as part of Schöner's preparations for using data from the Carta marina on his 1520 globe. ${ }^{228}$ This is confirmed by a difference between the printed sheet 6 and manuscript sheet 6A: on the printed sheet no legend appears in the Gulf of Guinea, but on the manuscript sheet there is a legend describing the islands in the São Tomé group (see Legend 6A.1)—and there is a similar legend in the same location on Schöner's 1520 globe.

We have few records that tell us much about Martin Waldseemüller, but his two multi-sheet world maps shed important light on his character. The maps are products of a cartographer with a great creative vision, and a great ambition to disseminate the latest cartographic knowledge to scholars throughout Europe. The fact that he and his colleagues were able to gather in the small town of Saint-Dié the diverse array of cartographic and geographic information necessary to produce these maps - rare manuscript maps, codices of Ptolemy's Geography, recent travel narratives, images of exotic animalstestifies to a remarkable drive and experience in research. Waldseemüller's willingness to cast aside all of the work that had gone into his 1507 map, and to create less than a decade later a new world map based on a new cartographic philosophy and almost entirely new sources, demonstrates a wonderful open-mindedness, energy, and thirst for knowledge. His Carta marina represents the culmination of more than a decade of thought about how the world should be mapped, and much painstaking research into the latest texts and images that could be used to create a rich and detailed image of the earth as it was known and traveled by human beings.

\footnotetext{
${ }^{223}$ See Chet Van Duzer, Johann Schöner's Globe of 1515: Transcription and Study (Philadelphia: American Philosophical Society, 2010).

${ }^{224}$ Schöner's globe of 1520 is in Nürnberg, Germanisches Nationalmuseum, WI 1, and is $87 \mathrm{~cm}$ in diameter. A tracing of the east Asian, American, and Atlantic portions of the globe may be found in Konrad Kretschmer, Die Entdeckung Amerika's in ihrer Bedeutung für die Geschichte des Weltbildes (Berlin: W. H. Kühl, 1892), plate 13; and in Franz Ritter von Wieser, Magalhães-Strasse und Austral-Continent auf den Globen des Johannes Schöner (Innsbruck: Verlag der Wagner'schen Universitaets-Buchhandlung, 1881; Amsterdam: Meridian Publishing, 1967), plate 1. A brief discussion of the globe, with transcription of some legends, is in Friedrich Wilhelm Ghillany, Der Erdglobus der Martin Behaim vom Jahre 1492 und der des Johann Schöner vom Jahre 1520 (Nürnberg: Druck der Campeschen Officin, 1842), pp. 13-18. See also Konrad Kretschmer, "Der Globus Johannes Schöner's vom Jahre 1520," in Beiträge zur alten Geschichte und Geographie: Festschrift für Heinrich Kiepert (Berlin: D. Reimer [Ernst Vohsen], 1898), pp. 113-23; and Norbert Holst, Mundus, Mirabilia, Mentalität: Weltbild und Quellen des Kartographen Johannes Schöner; eine Spurensuche (Frankfurt [Oder]: Scrîpvaz-Verlag, 1999), pp. 57-63.

${ }^{225}$ Holst in his Mundus, Mirabilia, Mentalität (see note 224) alludes to Schöner's borrowings from the Carta marina on Schöner's 1520 globe. I hope to explore these borrowings in more detail in the future, but can confirm that several legends in Africa on the 1520 globe come from the Carta marina. ${ }^{226}$ These corrections are listed by Joseph Fischer and Franz Ritter von Wieser, Die älteste Karte mit dem Namen Amerika (see note 9), pp. 20-21; and John W. Hessler, "Correcting Waldseemüller: Analysis of Hyperspectral Images of the Pastedown Shield on the 1516 Carta Marina," written in 2008 and available at http://www.kislakfoundation.org/download/Hessler-Analysis_of_Hyperspectral_Images.pdf.

${ }^{227}$ R. A. Skelton, in his "Bibliographical Note" in Ptolemy, Geographia, Strassburg, 1513 , p. xx, says that the red lines were drawn on the sheets of the map before the sheets were printed. But Elizabeth Harris, in "The Waldseemüller World Map: A Typographic Appraisal," Imago Mundi 37 (1985), pp. 30-53, at 31, as well as multispectral images made by the Library of Congress of both the 1507 and 1516 maps, confirm that, as one would expect, the grid of red lines was drawn after the sheets had been printed.

${ }^{228}$ In fact, Schöner copied by hand a brief study that discusses the process of transferring cartographic data from maps to globes. This text is in Vienna, Österreichische Nationalbibliothek, MS Vind. 3505, ff. 124v-125r, and is transcribed by Dana Bennett Durand, The ViennaKlosterneuburg Map Corpus of the Fifteenth Century: A Study in the Transition from Medieval to Modern Science (Leiden: E. J. Brill, 1952), pp. 364-367, with discussion on pp. 163-164.
} 
Open Access This chapter is licensed under the terms of the Creative Commons Attribution 4.0 International License (http://creativecommons.org/ licenses/by/4.0/), which permits use, sharing, adaptation, distribution and reproduction in any medium or format, as long as you give appropriate credit to the original author(s) and the source, provide a link to the Creative Commons license and indicate if changes were made.

The images or other third party material in this chapter are included in the chapter's Creative Commons license, unless indicated otherwise in a credit line to the material. If material is not included in the chapter's Creative Commons license and your intended use is not permitted by statutory regulation or exceeds the permitted use, you will need to obtain permission directly from the copyright holder. 